\title{
A SURVEY OF THE SYSTEMATIC WOOD ANATOMY OF THE RUBIACEAE
}

by

\author{
Steven Jansen ${ }^{1}$, Elmar Robbrecht ${ }^{2}$, Hans Beeckman ${ }^{3}$ \& Erik Smets ${ }^{1}$
}

\begin{abstract}
SUMMARY
Recent insight in the phylogeny of the Rubiaceae, mainly based on macromolecular data, agrees better with wood anatomical diversity patterns than previous subdivisions of the family. The two main types of secondary xylem that occur in Rubiaceae show general consistency in their distribution within clades. Wood anatomical characters, especially the fibre type and axial parenchyma distribution, have indeed good taxonomic value in the family. Nevertheless, the application of wood anatomical data in Rubiaceae is more useful in confirming or negating already proposed relationships rather than postulating new affinities for problematic taxa. The wood characterised by fibre-tracheids (type I) is most common, while type II with septate libriform fibres is restricted to some tribes in all three subfamilies. Mineral inclusions in wood also provide valuable information with respect to systematic relationships.
\end{abstract}

Key words: Rubiaceae, systematic wood anatomy, classification, phylogeny, mineral inclusions

\section{INTRODUCTION}

The systematic wood anatomy of the Rubiaceae has recently been investigated by us and has already resulted in contributions on several subgroups of the family (Jansen et al. 1996, 1997a, b, 1999, 2001; Lens et al. 2000). The present contribution aims to extend the wood anatomical observations to the entire family, surveying the secondary xylem of all woody tribes on the basis of literature data and original observations. Although Koek-Noorman contributed a series of wood anatomical studies to the Rubiaceae in the 1970's, there are two principal reasons to present a new and comprehensive overview on the wood anatomical variation. At first, the work of KoekNoorman mainly emphasised neotropical representatives, and secondly, the taxonomic framework of the family has entirely changed.

This paper starts with a historical survey of previous contributions including a comprehensive bibliography of wood anatomical literature of the family. This section does not aim at completeness but is meant to comment on the most important studies.

1) Laboratory of Plant Systematics, Institute of Botany and Microbiology, K.U. Leuven, Kasteelpark Arenberg 31, B-3001 Leuven, Belgium.

2) National Botanic Garden of Belgium, Domein van Bouchout, B-1860 Meise, Belgium.

3) Royal Museum for Central Africa, Leuvensesteenweg 13, B-3080 Tervuren, Belgium. 
A general introduction to the subfamilial and tribal classification of the Rubiaceae is given and presently available hypotheses on the phylogeny of the family are surveyed and summarised in a hypothetical tree. This new taxonomic framework is also compared to the latest overall classification system (Robbrecht 1988, 1994). The major part of this paper focuses on the wood anatomical variation within the Rubiaceae and discusses the systematic significance of the wood types. In order to elucidate the evolution of the secondary xylem, wood anatomical characters are plotted on the hypothetical tree. The present work also illustrates the distribution and taxonomic value of mineral inclusions in wood of Rubiaceae. A short wood anatomical comparison between Rubiaceae and related families is given in a final section.

\section{Historical survey of the systematic wood anatomy of the Rubiaceae}

Upon scanning early studies from the 19th century, the work of Van Riemsdijk (1875) is, as far as we know, one of the oldest works describing wood anatomy of Rubiaceae. Figure 1 shows his drawing of a transverse section of Coffea wood. This Dutch anatomist paid attention to seven genera of Rubiaceae and described in detail structures such as the distribution of axial parenchyma, disjunctive ray parenchyma cell walls, crystals, pitting of parenchyma cells and growth rings. However, general wood anatomical characters of the family were not discussed. A major contribution to systematic wood anatomy of the dicotyledons from that period was made by Solereder $(1885,1893,1899)$ who investigated c. 40 rubiaceous genera. Thereby, he was able to discuss general characters of the wood structure of Rubiaceae.

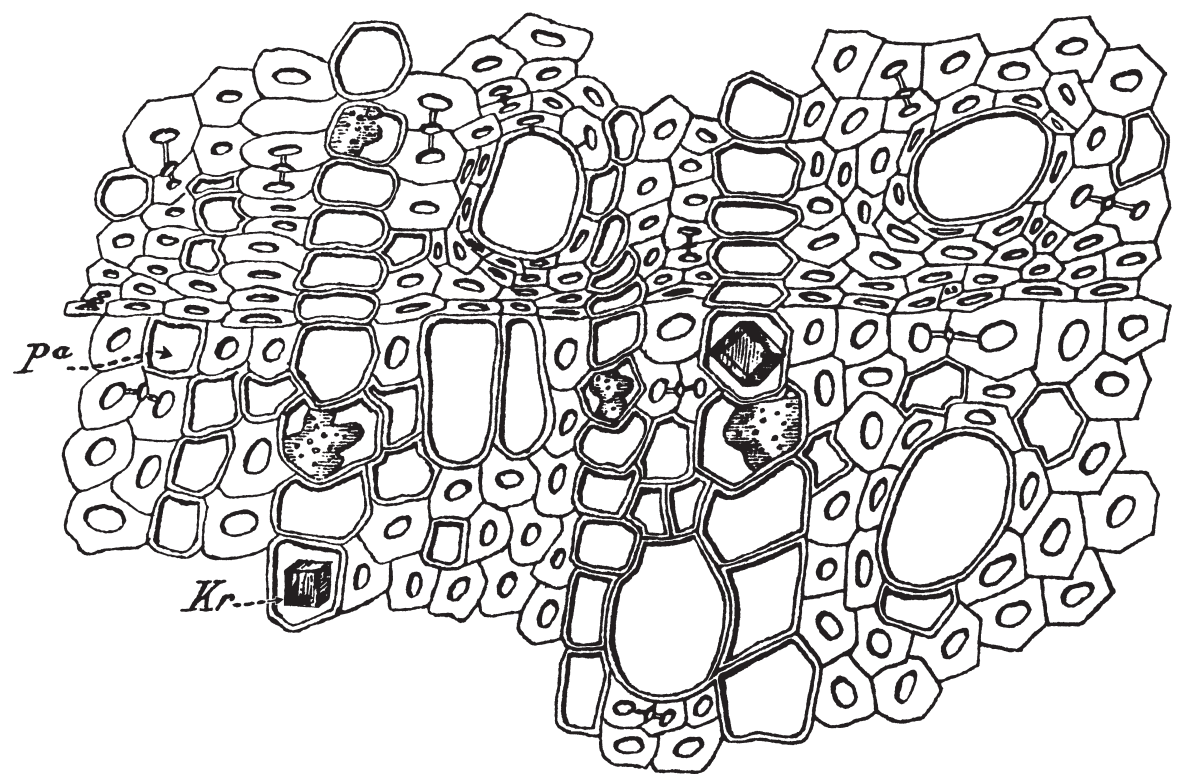

Fig. 1. Drawing of a transverse section of the wood of Coffea arabica; $\mathrm{pa}=$ axial parenchyma cell; $\mathrm{kr}=$ prismatic crystal (Van Riemsdijk 1875). 
An important wood anatomical survey of the major tree and shrub species from Indonesia was published by Moll and Janssonius (1926) in volume IV of their "Micrographie des Holzes der auf Java vorkommenden Baumarten". This comprehensive work includes very detailed descriptions of the secondary xylem of 26 rubiaceous genera. The application of precise terminology, accuracy and the abundant quantitative data (e.g. on the thickness of cell walls) that were compiled by Janssonius provide such a wealth of wood structural information that most of their data are even more comprehensive than most present wood anatomical descriptions. For instance, the sporadic occurrence of helical thickenings in axial parenchyma cells of a specimen of Lasianthus purpureus was observed for the first time (Moll \& Janssonius 1926: 245). With numerous original observations and taxonomic comments, Metcalfe's and Chalk's (1950) "Anatomy of the Dicotyledons" represents the most important contribution to the vegetative anatomy of the Rubiaceae from the first half of the 20th century. These authors accumulated data from literature and new observations of all together c. 150 rubiaceous genera.

Moreover, many wood anatomical descriptions, mostly of a selected number of rubiaceous species or genera often from restricted regions, have been published. A few that may be briefly mentioned are for instance: "Commercial timbers of India" (Pearson \& Brown 1932), "Woods of northeastern Peru" (Williams 1936), "Manuel d'identification des bois commerciaux, nr. 2, Afrique guinéo-congolaise" (Normand \& Paquis 1976), and “Atlas d'identification des bois de l'Amazonie et des régions voisines" (Détienne \& Jacquet 1983). Because detailed microscopic observations and systematic conclusions are beyond the scope of these works, there is no need to consider them in detail here.

From the late 1960's towards the 1980's a series of wood anatomical papers on a large number of Rubiaceae was published by Koek-Noorman. After two general papers on the wood structure of South American (mainly Surinam) Rubiaceae (KoekNoorman 1969a, b), special attention was given to the following tribes (in the delimitation of Bremekamp 1966 followed by her): Cinchoneae, Coptosapelteae, Naucleeae (Koek-Noorman 1970), Gardenieae, Ixoreae, Mussaendeae (Koek-Noorman 1972), Vanguerieae, Cinchoneae, Condamineeae, Rondeletieae (Koek-Noorman \& Hogeweg 1974), and Henriquezieae (Koek-Noorman 1980; also studied by Rogers 1981, 1984). Somewhat later, she collaborated with Puff in forwarding wood anatomical evidence for his redelimitation of the Anthospermeae and Paederieae (Koek-Noorman \& Puff $1983,1991)$. She distinguished two main types of secondary xylem and these types were largely found to be in accordance with the generic, tribal, and to some extent subfamilial concepts of Bremekamp (1952, 1966) and Verdcourt (1958) (Koek-Noorman 1977). Moreover, Koek-Noorman and Hogeweg (1974) applied cluster analysis using 125 wood anatomical characters in three tribes of the Rubiaceae. Irrespective of whether all varying features in their descriptions are given equal weight, or whether preferential character weighing is applied, the cluster analysis remains virtually the same with a very distinct bipartition. The success of numerical methods obtained for the Rubiaceae was further explored by Hogeweg and Koek-Noorman (1975). Apart from our own investigations, the most recent contribution to comparative wood 
anatomy of Rubiaceae is from Ter Welle et al. (1983). They examined the wood structure of nearly all genera of the Guettardeae and presented suggestions for taxonomic revisions of some genera.

Ecological approaches to the wood anatomy of the Rubiaceae were made by few authors. Koek-Noorman (1976) and Carlquist (1992) found wood anatomical evidence to suggest that some representatives of the Rubieae, which predominantly is a herbaceous tribe, have radiated into more temperate climates where secondary woodiness has occurred (e.g. Galium, Rubia).

The study of fossil woods is an important aspect of systematic wood anatomy. The following fossil woods have been assigned to the Rubiaceae: Rubioxylon naucleoides (Hofmann 1952; Oligocene), Rubioxylon vincenti (Koeniguer 1975; Pliocene), and cf. Rubioxylon vincenti (Lemoigne 1978; Miocene), Canthium omoensis, Rothmannia aethiopica (Gros 1990; Pliocene), Mitragynoxolon gevini (Gevin et al. 1971; Oligocene/Miocene; Gros 1990). A specimen of Grangeonixylon danguense is said to be either Rubiaceae or Apocynaceae (Sakala et al. 1999). However, some of these woods may need to be re-evaluated regarding their identification or questionable age.

In summary, most studies of the wood tissue of the Rubiaceae undertaken are limited to regional surveys, except for the series of publications by Koek-Noorman. Most authors agreed that the anatomical structure of the woods is remarkably similar, exhibiting fewer differences than is usual in much smaller natural groups than the Rubiaceae.

\section{Bibliography of the systematic wood anatomy of the Rubiaceae}

A bibliography of systematic wood anatomy of the Rubiaceae is given below. The aim of this bibliography is to provide a guide to the available literature. For a more complete list including 160 full references on Rubiaceae, the "Bibliography of Systematic Wood Anatomy of Dicotyledons" (Gregory 1994) is recommended. We also refer here to the databases of the Royal Botanic Gardens, Kew (2000a, b), which are very useful for accessing recent taxonomic literature of many taxa.

In order to keep the length of the bibliography down, only references with microscopical observations are included. The authors are listed in chronological order. Generic names are as in the papers cited.

Van Riemsdijk (1875): Cinchona, Coffea, Greenea, Guettarda: Nauclea, Psychotria, Uncaria. Solereder (1885): Alberta, Anthospermum, Antirhea, Bikkia, Catesbaea, Chiococca, Cinchona, Coffea, Coussarea, Damnacanthus, Discospermum, Faramea, Gaillonia, Gardenia, Guettarda, Hamelia, Hamiltonia, Hedyotis, Ixora, Knoxia, Ladenbergia, Lasianthus, Leptodermis, Morinda, Mussaenda, Nauclea, Nenax, Pachystigma, Paederia, Portlandia, Psychotria, Psyllocarpus, Retiniphyllum, Rondeletia, Rudgea, Scolosanthus, Uncaria, Urophyllum, Vangueria, Wendlandia.

Burgerstein (1912): Calycophyllum, Coutarea.

Kanehira (1921): Chomelia, Diplospora, Gardenia, Morinda, Nauclea, Psychotria, Randia, Timonius, Wendlandia.

Brown (1922): Bobea, Canthium, Coprosma, Gardenia, Morinda, Psychotria, Straussia. Lecomte (1922): Breonia, Craterispermum, Nauclea, Pyrostria, Schismatoclada. Record and Garrat (1925): Gardenia. 
Moll and Janssonius (1926): Adina, Breonia, Canthium, Cinchona, Diplospora, Guettarda, Hymenodictyon, Hypobathrum, Ixora, Lasianthus, Mitragyna, Morinda, Mussaenda, Nauclea, Nostolachma, Pavetta, Prismatomeris, Psychotria, Randia, Sarcocephalus, Scyphiphora, Tarenna, Urophyllum, Vangueria, Wendlandia, Zuccarinia.

Kribs (1928): Amaioua, Isertia, Palicourea, Psychotria.

Panshin (1932): Scyphiphora.

Pearson and Brown (1932): Adina, Breonia, Canthium, Gardenia, Hymenodictyon, Mitragyna, Morinda, Nauclea, Randia, Sarcocephalus.

Chalk et al. (1933): Mitragyna.

Milanez (1936): Calycophyllum.

Williams (1936): Alibertia, Alseis, Anisomeris, Bertiera, Bothriospora, Calycophyllum, Capirona, Cephaelis, Chimarrhis, Cinchona, Coussarea, Coutarea, Duroia, Faramea, Ferdinandusa, Genipa, Gonzalagunia, Hamelia, Hippotis, Isertia, Ixora, Ladenbergia, Machaonia, Macrocnemum, Palicourea, Pentagonia, Posoqueria, Psychotria, Randia, Remijia, Rudgea, Sickingia, Sommera, Sphinctanthus, Tocoyena, Uncaria, Warszewiczia.

Record and Hess (1943): General description of wood anatomical features.

Lemesle (1947a): Cephaelis, Psychotria.

Lemesle (1947b): Cephaelis, Psychotria, Manettia, Richardsonia.

Metcalfe and Chalk (1950): General discussion of wood anatomical characters based on c. 150 genera.

Fouarge et al. (1953): Mitragyna, Sarcocephalus.

Desch (1954): Adina, Aidia, Anthocephalus, Canthium, Diplospora, Gardenia, Hymenodictyon, Ixora, Jackiopsis, Mitragyna, Morinda, Mussaendopsis, Nauclea, Neonauclea, Randia, Scyphiphora, Timonius, Urophyllum.

James (1954): Scyphiphora.

De Freitas (1955): Timonius.

Normand (1960): Canthium, Corynanthe, Gardenia, Morinda, Nauclea, Mitragyna.

Brazier and Franklin (1961): Adina, Calycophyllum, Gardenia, Mitragyna, Nauclea.

Fouarge and Gérard (1964): Aidia, Corynanthe.

Lebacq and Dechamps (1967): Aidia, Belonophora, Canthium, Colletoecema, Crossopteryx, Cuviera, Gaertnera, Gardenia, Massularia, Mitragyna, Morinda, Pausinystalia, Psychotria, Rothmannia.

Kribs (1968): Adina, Calycophyllum, Corynanthe, Genipa, Mitragyna, Neonauclea, Sarcocephalus.

Koek-Noorman (1969a): General description of the wood structure of the Rubiaceae.

Koek-Noorman (1969b): Alibertia, Amaioua, Capirona, Cephaelis, Chimarrhis, Chomelia, Coussarea, Duroia, Elaeagia, Faramea, Genipa, Guettarda, Hamelia, Henriquezia, Hillia, Isertia, Ixora, Malanea, Mapouria, Morinda, Naletonia, Pagamea, Palicourea, Posoqueria, Psychotria, Randia, Retiniphyllum, Ronabea, Rosenbergiodendron, Rudgea, Schradera, Sickingia, Simira, Strempelia, Uncaria, Warszewiczia.

Koek-Noorman (1970): Adina, Anthocephalus, Breonia, Calycophyllum, Capirona, Cephalanthus, Cinchona, Corynanthe, Coutarea, Crossopteryx, Exostema, Ferdinandusa, Hymenodictyon, Macrocnemum, Mitragyna, Nauclea, Neonauclea, Uncaria.

Koek-Noorman (1972): Acranthera, Alibertia, Amaioua, Amaralia, Aulacocalyx, Bertiera, Borojoa, Casasia, Duroia, Galiniera, Gardenia, Genipa, Gonzalagunia, Gouldia, Hamelia, Heinsenia, Heinsia, Hippotis, Ibetralia, Isertia, Ixora, Kutchubaea, Leptactina, Leucolophus, Maschalocorymbus, Mussaenda, Mycetia, Pavetta, Pentagonia, Pleiocarpidia, Randia, Rennellia, Retiniphyllum, Rothmannia, Rutidea, Sommera, Stachyarrhena, Tarenna, Tocoyena, Tricalysia, Urophyllum.

Ridsdale et al. (1972): Maschalodesme, Versteegia.

Mennega and Koek-Noorman (1973): Gaertnera, Pagamea. 
Ayensu and Bentum (1974): Mitragyna, Nauclea.

Koek-Noorman and Hogeweg (1974): Alseis, Badusa, Bathysa, Bikkia, Calycophyllum, Canthium, Capirona, Cascarilla, Chimarrhis, Cinchona, Condaminea, Cuviera, Dolicholobium, Elaeagia, Exostema, Ferdinandusa, Gleasonia, Greenea, Hymenodictyon, Joosia, Ladenbergia, Lindenia, Loretoa, Macbrideina, Macrocnemum, Morierina, Mussaendopsis, Pinckneya, Plectronia, Pogonopus, Portlandia, Remijia, Rondeletia, Rustia, Rytigynia, Simira, Vangueria, Warszewiczia, Wendlandia.

Leroy (1975): Hallea, Mitragyna.

Lomibao (1975): Adina, Canthium, Greeniopsis, Guettarda, Neonauclea.

Koek-Noorman (1976): Amaracarpus, Coprosma, Crucianella, Declieuxia, Diodia, Galium, Hemidiodia, Othiophora, Plocama, Pomax, Psychotria, Relbunium, Rubia, Spermacoce.

Normand and Paquis (1976): Brenania, Canthium, Craterispermum, Gaertnera, Morinda, Nauclea, Hallea, Hymenodictyon, Pausinystalia.

Fundter and Wisse (1977): Adina, Mastixiodendron, Nauclea.

Koek-Noorman (1977): Survey of wood types of Rubiaceae.

Vales and Babos (1977): Ceratopyxis.

Meylan and Butterfield (1978): Coprosma.

Miles (1978): Adina, Calycophyllum, Gardenia, Mitragyna, Nauclea.

Aiello (1979): Nernstia, Portlandia.

Bridson et al. (1980): Phellocalyx.

Koek-Noorman (1980): Gleasonia, Henriquezia, Platycarpum.

Rogers (1981): Gleasonia, Henriquezia, Platycarpum .

Détienne et al. (1982): Amaioua, Capirona, Chimarrhis, Coussarea, Duroia, Genipa, Isertia, Palicourea, Posoqueria.

Fernandez and Peters (1982): Coffea.

Purkayastha (1982): Adina, Breonia, Canthium, Catunaregam, Gardenia, Hymenodictyon, Ixora, Mitragyna, Morinda, Nauclea, Neonauclea, Randia, Tricalysia, Wendlandia.

Rudall (1982): Canthium.

Détienne and Jacquet (1983): Alibertia, Alseis, Amaioua, Anisomeris, Bothriospora, Calycophyllum, Capirona, Chimarrhis, Chomelia, Cinchona, Coussarea, Coutarea, Duroia, Ferdinandusa, Genipa, Guettarda, Henriquezia, Isertia, Ladenbergia, Loretoa, Macbrideina, Macrocnemum, Morinda, Palicourea, Posoqueria, Psychotria, Randia, Remijia, Sickingia, Stachyarrhena, Straussia, Tocoyena, Warszewiczia.

Koek-Noorman and Puff (1983): Aitchisonia, Anthospermum, Carpacoce, Coprosma, Crocyllis, Leptodermis, Nenax, Opercularia, Paederia, Phyllis, Pomax, Neogaillonia, Normandia, Spermadictyon.

Vales (1983a, b): Acunaeanthus, Ariadne, Ceratopyxis, Mazaea, Phyllomelia.

Ter Welle et al. (1983): Antirhea, Bobea, Chomelia, Dichilanthe, Guettarda, Machaonia, Malanea, Timonius.

Gill and Onuja (1984): Canthium, Nauclea.

Gomes and Marchiori (1984): Calycophyllum.

Ohtani (1984): Damnacanthus, Lasianthus.

Rogers (1984): Gleasonia, Henriquezia, Platycarpum.

Dechamps (1985): Alseis, Amaioua, Calycophyllum, Capirona, Chimarrhis, Chomelia, Cinchona, Coffea, Coussarea, Duroia, Faramea, Genipa, Gonzalagunia, Guettarda, Isertia, Ixora, Ladenbergia, Macbrideina, Macrocnemum, Pagamea, Palicourea, Posoqueria, Psychotria, Remijia, Rudgea.

Vales and Süss (1985a): Ceratopyxis, Phyllomelia.

Vales and Süss (1985b): Acunaeanthus, Ariadne, Neomazaea.

Ohtani (1986): Lasianthus.

Ohtani (1987): Damnacanthus. 
Richter and Schmitt (1987): Cosmocalyx.

Coulaud (1988, 1989): Gaertnera, Genipa.

Barajas-Morales and Gomez (1989): Exostema, Guettarda, Hintonia.

Schweingruber (1990): Asperula, Crucianella, Galium, Putoria, Rubia.

International Tropical Timber Organisation and Research Institute of Wood Industry (1991):

Adina, Anthocephalus, Hymenodictyon, Mitragyna, Mussaendopsis, Nauclea.

Koek-Noorman and Puff (1991): Paederia.

Carlquist (1992): Coprosma, Galium.

Oteng-Amoako (1992): Anthocephalus, Mastixiodendron, Nauclea, Neonauclea.

Acevedo and Kikita (1994): Alseis, Calycophyllum, Chimarrhis, Genipa, Simira.

Carreras and Dechamps (1995): Acrosynanthus, Calycophyllum, Genipa, Guettarda.

Vrydaghs et al. (1995): Adina, Breonadia, Haldina, Hallea, Metadina, Mitragyna, Nauclea, Neonauclea, Ochreinauclea, Pertusadina, Sarcocephalus.

Jansen et al. (1996): Gaertnera, Pagamea.

Purkayastha (1996): Breonia, Canthium, Catunaregam, Deccania, Gardenia, Guettarda, Haldina, Hymenodictyon, Ixora, Mitragyna, Morinda, Neonauclea, Ochreinauclea, Tricalysia, Wendlandia.

Barros and Callado (1997): Coussarea, Psychotria.

Jansen et al. (1997a): Chassalia, Chazaliella, Gaertnera, Hymenocoleus, Pagamea, Psychotria. Jansen et al. (1997b): Argocoffeopsis, Calycosiphonia, Coffea, Psilanthus.

Ogata and Kalat (1997): Gynopachis, Rothmannia, Tarenna, Timonius.

Gasson et al. (1998): Fernelia.

Sosef et al. (1998): Adinauclea, Canthium, Gardenia, Guettarda, Haldina, Hymenodictyon, Ixora, Jackiopsis, Ludekia, Metadina, Mussaendopsis, Nauclea, Neonauclea, Ochreinauclea, Pertusadina, Porterandia, Scyphiphora, Timonius, Urophyllum.

Jansen et al. (1999): Captaincookia, Cladoceras, Dictyandra, Doricera, Duperrea, Homollea, Ixora, Leptactina, Myonima, Nichallea, Pachystylus, Pavetta, Rutidea, Tarenna, Tennantia, Versteegia.

Ceccantini and Angyalossy-Alfonso (2000): Bathysa.

Lens et al. (2000): Canthium, Cuviera, Fadogia, Fadogiella, Keetia, Lagynias, Meyna, Pachystigma, Psydrax, Pygmaeothamnus, Pyrostria, Rytigynia, Tapiphyllum, Vangueria, Vangueriopsis.

Dessein et al. (2001b): Virectaria.

Jansen et al. (2001): Commitheca, Coussarea, Craterispermum, Damnacanthus, Declieuxia, Faramea, Gynochtodes, Hindsia, Lasianthus, Leucolophus, Maschalocorymbus, Morinda, Pleiocarpidia, Poecilocalyx, Praravinia, Prismatomeris, Rennellia, Saldinia, Stelechantha, Triainolepis, Trichostachys, Urophyllum.

Piesschaert et al. (In press): Pagameopsis.

\section{The intrafamilial classification of the Rubiaceae}

At the beginning of our wood anatomical project, we followed the then latest overal classification system of the Rubiaceae (Robbrecht 1988, 1994), which was based on character analysis of a number of features including wood anatomy (Fig. 2). It was our initial intention to sample wood from all woody tribes in Robbrecht's four subfamilies.

Already in the 1990's, Bremer and Jansen (1991) and Bremer (1992) used comparative restriction site mapping of cpDNA to test relationships. The most remarkable new hypothesis forwarded then no doubt was a close relationship between the uniovulate Chioccoceae and multiovulate genera at that time placed in Cinchoneae or 


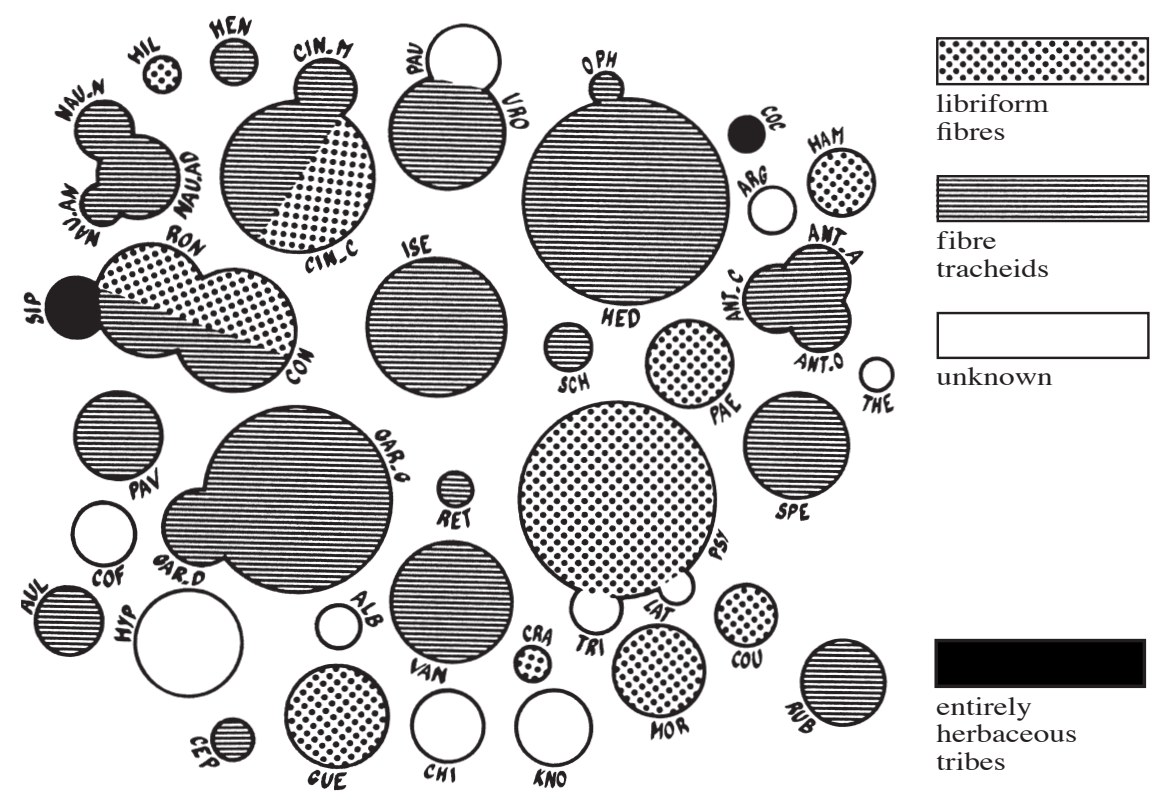

Fig. 2. Robbrecht's (1988: fig. 8) analysis of the distribution of the two wood types in Rubiaceae, plotted on his Venn diagram of the tribes of the family. The occurrence of fibre-tracheids in some anomalous members of the Guettardeae is not indicated.

Condamineeae-Portlandiinae. During recent years, much progress in the phylogenetic understanding of the Rubiaceae was made by the analysis of macromolecular data (entire family: Bremer 1996; Bremer et al. 1995, 1999; Manen \& Natali 1996; Bremer \& Thulin 1998; Rubioideae: Natali et al. 1996; Andersson \& Rova 1999; Bremer \& Manen 2000; Piesschaert et al. 2000b; Ixoroideae: Andreasen \& Bremer 1996, 2000; Andreasen et al. 1999; Rova 1999; Cinchonoideae: Bremer \& Thulin 1998; Rova 1999). The congruence between the results of all these authors using five different DNA sequences is remarkable, and three subfamilies obviously emanate: Rubioideae, Cinchonoideae s. str. and Ixoroideae s.1. These three subfamilies are also corroborated by phytochemical findings (Young et al. 1996). They are characterised by respectively anthraquinones, indole alkaloids and iridoids. We have manually constructed a hypothetical tree that summarises the relationships in all the above papers (Fig. 3) without conducting a new phylogenetic analysis. The intrafamilial classification according to Robbrecht $(1988,1994)$ is indicated in the same figure.

The subfamily Ixoroideae has been enlarged during recent years. This is partly due to the collapse of the former subfamily Antirheoideae. Vanguerieae, Retiniphylleae and Alberteae that were previously included in that subfamily are now grouped in the core Ixoroideae. Molecular evidence is unanimous in placing Craterispermeae and Knoxieae in the Rubioideae; these two former Antirheoideae tribes morphologically deviated by heterostyly and raphides. The last three tribes of the Antirheoideae should be included in Cinchonoideae: the Guettardeae are close to the Rondeletieae, for the 


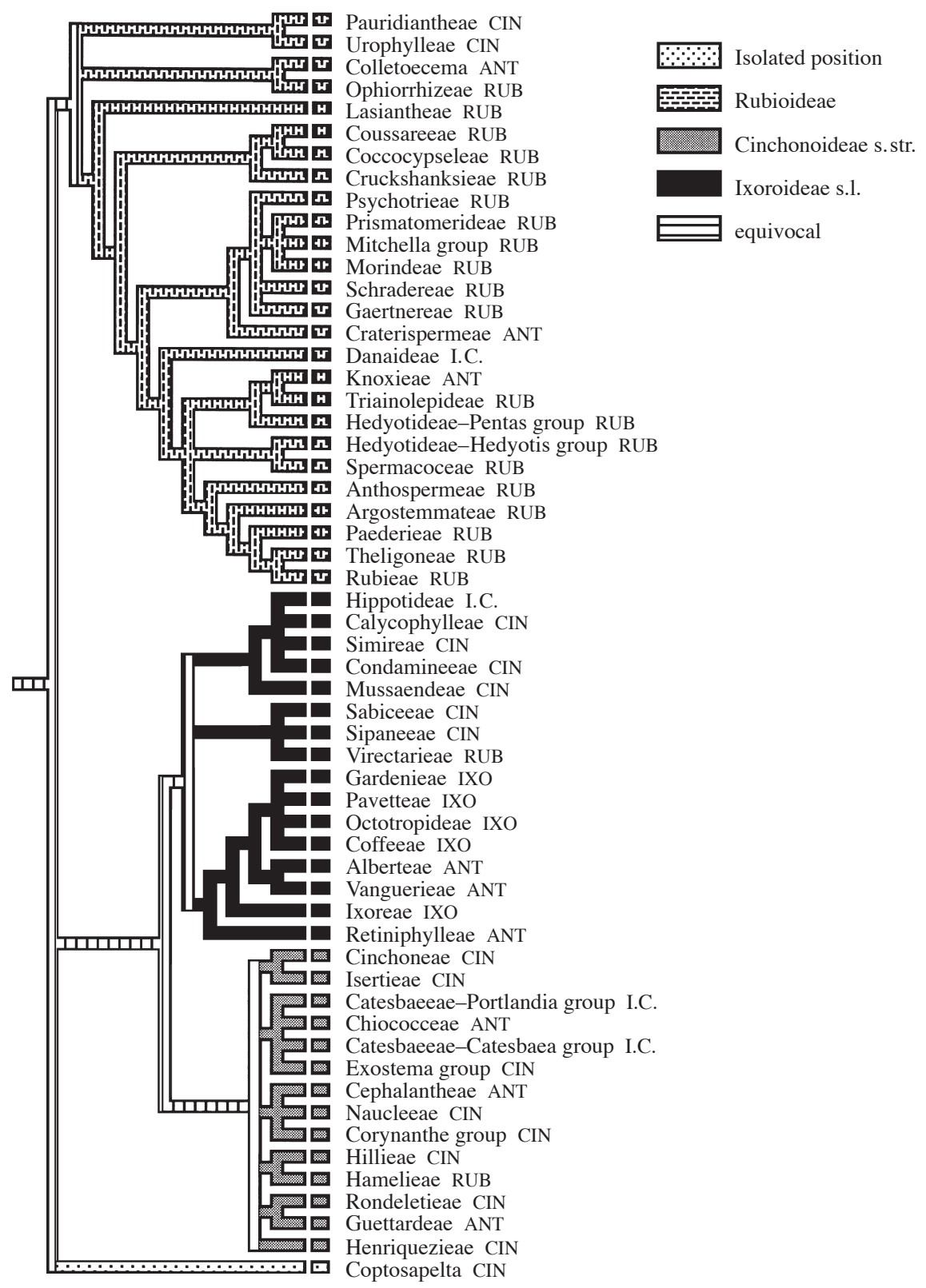

Fig. 3. Subdivision of the Rubiaceae followed in this study; hypothetical tree mainly based on Bremer \& Thulin ( $r b c \mathrm{~L} ; 1998)$, Andersson \& Rova (rps16-intron; 1999), Andreasen et al. (ITS, $r b c \mathrm{~L} ; 1999)$, Bremer et al. (rbcL, $n d h \mathrm{~F} ; 1999)$, Andreasen \& Bremer (ITS, $r b c \mathrm{~L} ; 2000)$, Piesschaert et al. ( $r p s 16$-intron; 2000a), Bremer \& Manen ( $r b c \mathrm{~L}, a t p \mathrm{~B}-r b c \mathrm{~L}, r p s 16$-intron; 2000), and Dessein et al. (rps16-intron, $r b c \mathrm{~L} ; 2001 \mathrm{a})$. The classification of Robbrecht $\left(1994^{*}\right)$ is indicated by the following abbreviations: ANT $=$ Antirheoideae, $\mathrm{CIN}=$ Cinchonoideae, $\mathrm{IXO}=$ Ixoroideae, $\mathrm{RUB}=$ Rubioideae, I.C. = Incertae sedis. ${ }^{*}$ Largely corresponding to Robbrecht (1988) as depicted in Figure 2. 
Table 1. Delimitation of the Rondeletieae and the former Condamineeae following Delprete (1999) and circumscription of the Rondeletieae according to Rova (1999); ${ }^{1)}$ Simireae according to many authors; ${ }^{2}$ Sipaneeae according to many authors; ${ }^{3)}$ Con.-Cal.-Hip.-Sim. = Condamineeae-Calycophylleae-Hippotideae-Simireae-complex; ? = wood type unknown. Tribal abbreviations follow Robbrecht (1994).

\begin{tabular}{|c|c|c|c|}
\hline \multicolumn{2}{|c|}{$\begin{array}{l}\text { Rondeletieae sensu latissimo } \\
\text { (Delprete 1999, with his informal groups) }\end{array}$} & \multirow{2}{*}{$\begin{array}{l}\text { Rova (1999) } \\
\text { Con.-Cal.-Hip.-Sim.3) }\end{array}$} & \multirow{2}{*}{$\begin{array}{l}\text { Wood type } \\
\text { II }\end{array}$} \\
\hline Bathysa group & Bathysa & & \\
\hline & Phitopsis & Con.-Cal.-Hip.-Sim. & $?$ \\
\hline Rondeletia complex & Rondeletia and segregates & Ron. s.s. & I \\
\hline Mazaea group & $\begin{array}{l}\text { Mazaea (syn. Ariadne, } \\
\text { Neomazaea), Phyllomelia }\end{array}$ & Ron. s.s. & I \\
\hline Augusta group & Augusta & close to Gar. / Pav. & I-II \\
\hline Simira group 1 ) & Simira & Sim. & II \\
\hline Sipanea group 2) & $\begin{array}{l}\text { Limnosipanea, Sipanea, } \\
\text { Steyermarkia }\end{array}$ & Sip. & (herbaceous) \\
\hline \multirow[t]{3}{*}{ Paleotropical genera } & Aleisanthia, Greenea & close to Ixoreae & I (Greenea) \\
\hline & Glionnetia, Spathichlamys & Ron. & $?$ \\
\hline & Wendlandia & close to Gar. / Pav. & I \\
\hline Former & Molopanthera & close to Hen. & $?$ \\
\hline Condamineeae & $\begin{array}{l}\text { Rustia, Tresanthera, Conda- } \\
\text { minea, Picardaea, Pogonopus, } \\
\text { Chimarrhis, Dioicodendron, } \\
\text { Dolichodelphys, Parachimarrhis }\end{array}$ & Con.-Cal.-Hip.-Sim. & $\begin{array}{l}\text { II (Rustia, } \\
\text { Condaminea, } \\
\text { Picardaea, } \\
\text { Pogonopus, } \\
\text { Chimarrhis) }\end{array}$ \\
\hline
\end{tabular}

Cephalantheae it was proved that they should return to their original position near the Naucleeae, and the Chiococceae are a relative of the Catesbaeeae. The last hypothesis is in the line of what Bremer (1992) already postulated, because Delprete (1996) proved that the former Portlandiinae should be merged with Catesbaeeae.

The circumscription of the subfamily Cinchonoideae, on the other hand, is narrowed when compared to its delimitation by Robbrecht $(1988,1994)$. The tribes Sipaneeae, Calycophylleae, and Condamineeae are now transferred to the Ixoroideae s.l., but Cephalantheae and Chiococceae are included in Cinchonoideae. Note that all available evidence places the genus Coptosapelta in a basal position to the rest of the family. It is unfortunate that Bremekamp's monogeneric tribe Coptosapelteae has been emended to be used for one of the largest tribes of the Cinchonoideae s.str. (Andersson \& Persson 1991). We exclude Coptosapelta and use the provisional designation “Corynanthe group” for Andersson's alliance.

In 1987, Rogers still complained about the unsettled state of the intrafamilial classification of the Rubiaceae. The recent work surveyed above now provides a comprehensive and phylogenetically strong framework. Nevertheless, there are still a few areas with major tribal delimitation problems, the major one no doubt the Rondeletieae 
and former Condamineeae. For these, conflicting, modern opinions exist (Table 1; Delprete 1999 versus Rova 1999), while the latter author also made provisional suggestions, such as a monophyletic Calycophylleae-Condamineeae-HippotideaeSimireae-complex. On our hypothetical tree (Fig. 3) we have kept these four tribes as a polytomy.

\section{MATERIALS AND METHODS}

The data in this paper are based on literature and original observations. The following taxa were not included in this study because they are entirely herbaceous: Cruckshanksieae, Knoxieae, Mitchella, Sipaneeae and Theligoneae.

The samples studied were from the wood collection of Tervuren (Belgium, Tw xylarium) or from the herbaria of BR, K, L, U, and MO. The diameter (in $\mathrm{cm}$ ) of each wood sample is included for branch wood; the diameter of mature wood samples is unknown and not reported. Wood blocks were sectioned and macerated according to standard methods (Jansen et al. 1998). The specimens were studied with a light miscroscope (LM; Leica DMLB) and a scanning electron microscope (SEM; Jeol JSM6400). Terminology follows the IAWA list (IAWA Committee 1989).

The species and specimens studied in our earlier contributions (Jansen et al. 1996, 1997a, b, 1999, 2001) are not repeated in this paper.

\section{Alphabetical list of material studied:}

Aidia cochinchinensis Lour., China Guandong, Forest Research Institue 1648 (Tw 42125) - A. micrantha (K.Schum.) Bullock ex F. White, Congo(-Kinshasa), C. Donis 2302 (Tw 32559)

Alberta humblotii Drake, Madagascar, Nonokambo à Varaissa, M.G. Cours 2369 (BR) - A. minor Baill., Madagascar, Tananarive, Antiaratro, Manjakatompo, G.E. Schatz et al. 1297 (BR)

Alibertia hadrantha Standl., Brazil, Amazones, B.A. Krukoff 5735 (Tw 34502) - A. myrciifolia K. Schum., Bolivia, Santa Cruz, Nee 36968 (Tw 51275), $2.3 \mathrm{~cm}$

Alseis smithii Standl., British Guyana, A.C. Smith 3236 (Tw 27346)

Amaioua intermedia Mart. ex Schult. \& Schult.f., Brazil, Matto-Grosso, B.A. Krukoff 1431 (Tw 34674)

Aoranthe castaneofulva (S.Moore) Somers, Congo, Wagemans 1748 (Tw 41262), $1.8 \mathrm{~cm}$

Atractogyne gabonii Pierre, Congo(-Kinshasa), J. Louis 5725 (Tw 35734), $1 \mathrm{~cm}$

Aulacocalyx lujae De Wild., Congo, Kouilou, R. Dechamps 13237 (Tw 49303), $1.7 \mathrm{~cm}-$ A. pallens subsp. letestui (Pellegr.) E.Figueiredo, Congo, Kouilou, R. Dechamps 13225 (Tw 49293), 2 cm A. talbotii (Wernham) Keay, Congo, Kouilou, R. Dechamps 13216 (Tw 49335), $1.5 \mathrm{~cm}$

Belonophora coriacea Hoyle, Congo, J. Louis 5916 (Tw 35790), $1.5 \mathrm{~cm}$ - B. coriacea Hoyle, Congo, Bumba, Dundus, Mortehan 760 (BR), $1 \mathrm{~cm}-$ B. lepidopoda (K.Schum.) Hutch. \& Dalziel, Congo, Kasai, R. Dechamps 617 (Tw 8528)

Bertiera aethiopica Hiern, Congo, Kouilou, R. Dechamps 13158 (Tw 49218), $1.5 \mathrm{~cm}-$ B. racemosa K.Schum. var. elephantina N.Hallé, Congo, Kouilou, R. Dechamps 13104 (Tw 49136), $2.2 \mathrm{~cm}$

Blepharidium mexicanum Standl., Mexico, Curtis 495 (Tw 49393)

Bobea cf. brevipes A.Gray, Hawaii, W. Stern 2975 (Tw 24144)

Bothriospora corymbosa (Benth.) Hook. f., Peru, L. Lebacq 1163 (Tw 16163)

Brenania brieyi (De Wild.) E. M.A.Petit, Cameroon, C.T.F.T. 1620 (Tw 30897)

Calochone acuminata Keay, Congo, Kouilou, R. Dechamps 13138 (Tw 49183), $0.5 \mathrm{~cm}$

Calycophyllum candidum DC., Cuba, Topes de Colantes, Prov. Cienfuegos, R. Dechamps \& R. Carreras s.n. (Tw 12188) - C. multiflorum Griseb., Argentina, Salta, Adm. Mac. De Bosq. s.n. (Tw 17817)

Calycosiphonia spathicalyx (K.Schum.) Robbr., Congo(-Kinshasa), forêt de Bululu, M'Vuazi, J. Dubois 1 (BR) 
Canephora madagascariensis J.F.Gmel., Madagascar, Majunga, L.J. Dorr et al. 3542 (Tw 46774)

Capirona decorticans Spruce, Venezuela, Amazonas, B. Maguire et al. 28613 (Tw 36294) - C. decorticans Spruce, Peru, Loreto, Servicia Forestal I 114 (Tw 25258)

Carphalea kirondron Baill., Madagascar, Nogent 8906 (Uw 15473)

Casasia calophylla A.Rich., Cuba, Pitarderio, near Cayuco, R. Dechamps 12121 (Tw 48637), $2.2 \mathrm{~cm}$

Catunaregam spinosa (Thunb.) Tirveng., India, Birla Institut Madhaya Pradesh s.n. (Tw 45205) - C. spinosa (Thunb.) Tirveng., Congo (-Kinshasa), Katanga, F. Malaisse 6970 (Tw 24242), $1 \mathrm{~cm}$

Chassalia bojeri Bremek. var. longifolia Bremek., Madagascar, Province Majunga, Station forestière d'Ampijoroa, c. $3 \mathrm{~km}$ from d'Andranofasika, L.J. Dorr et al. 2984A (Tw 4471)

Chimarrhis brevipes Steyerm., Venezuela, Amazonas, B. Maguire et al. 27971 (Tw 36277) - C. turbinata DC., Surinam, Stahel 261 (Tw 25849)

Chiococca alba (L.) Hitchc., Cuba, Guisa, Prov. Gramma, R. Dechamps 12268 (Tw 48732), $1 \mathrm{~cm}$

Chione cubensis A.Rich., Cuba, INDAF 61 (Tw 20761)

Colletoecema dewevrei (De Wild.) E.M.A.Petit, Congo(-Kinshasa), R. Dechamps 7 (Tw 8040)

Coprosma lucida J.R.Forst. \& G.Forst., New Zealand, Lewalle s.n. (Tw 46635) - C. montana Hillebr., U.S.A., New Mexico, Santa Fé, S.H. Lamb s.n. (Tw 32040) - C. ochracea W.R.B.Oliv. var. rockiana W.R.B.Oliv., U.S.A., Hawaii, S.H. Lamb 21 (Tw 35950) - C. pubens A.Gray, U.S.A., Hawaii, W. Stern 2977 (Tw 24145), $2 \mathrm{~cm}$ - C. rhynchocarpa A.Gray, Hawaii, Curtis s.n. (Tw 43920)

Coptosapelta olaciformis (Merr.) Elmer, Philippines, Sungao, C.A. Wenzel 2719 (BR), 6 mm

Corynanthe pachyceras K.Schum., Ivory Coast, P. Détienne 18 (Tw 29860)

Cosmibuena grandiflora (Ruiz \& Pav.) Rusby, Colombia, J. Cuatrecasas 15287 (Tw 39418)

Crossopteryx febrifuga (Afzel. ex G.Don) Benth., Congo (-Kinshasa), Ghesquiere s.n. (Tw 666)

Crucianella maritima L., Portugal, Algarve, Aguia, R. Dechamps 7240 (Tw 43547), $0.5 \mathrm{~cm}$

Danais cernua Baker, Madagascar, Toliara, B. Randriamampionona 15 (MO), $6 \mathrm{~mm}-$ D. pubescens Baker, Madagascar, Antannanarivo, L.J. Dorr et al. 3618 (Tw 46785), $0.7 \mathrm{~cm}-$ D. xanthorrhoea (K.Schum.) Bremek., Scheffer 195 (BR)

Dendrosipanea revoluta Steyerm., Venezuela, Amazonas, B. Maguire et al. 41665 (Tw 36217), $0.8 \mathrm{~cm}$

Dialypetalanthus fuscescens Kuhlm., Brazil, São Lourenço, 14 km Rio Madeira, above Matuparaná, Amazonas, G. Prance 8967 (Uw 23666); Bolivia, Beni, W.R. Anderson 11865 (Uw 26787), $2.5 \mathrm{~cm}$

Didymosalpinx lanciloba (S.Moore) Keay, Congo (-Kinshasa), Haut-Congo, J. Louis 3926 (Tw 35549)

Diodia scandens Sw.,Congo (-Kinshasa), Cuvette, J. Louis 1916 (Tw 33319), $0.6 \mathrm{~cm}$

Doricera trilocularis (Balf. f.) Verdc., Rodrigues, Solitude, Tirvengadum 908 (K), $0.5 \mathrm{~cm}$

Duroia aquatica (Aubl.) Bremek., French Guyana, Bus. For. Guya. 290 (Tw 22174) - D. petiolaris Spruce ex K.Schum., Brazil, Amazonas, B.A. Krukoff 6699 (Tw 38639)

Elaeagia utilis (Goudot) Wedd., Colombia, J. Cuatracasas 21651 (Tw 39791)

Erithalis odorifera Jacq., Antilles Françaises, Guadeloupe, Rollet, CTFT 1149 (Tw 47650)

Euclinia longiflora Salisb., Congo(-Kinshasa), J. Louis 6452 (Tw 38297), $0.8 \mathrm{~cm}$

Exostema mexicanum A.Gray, Mexico, Campeche, INIF 165 (Tw 19185)

Ferdinandusa chlorantha (Wedd.) Standl., Peru, L. Lebacq 295 (Tw 16295) - F. hirsuta Standl., Brazil, Amapa, B. Maguire et al. 51968 (Tw 37554)

Feretia aeruginescens Stapf, Congo (-Kinshasa), Kasapa, F. Malaisse 7996 (BR), $1 \mathrm{~cm}-$ F. apodanthera Delile, Senegal, Sasamance, J. De Wolf 5 (Tw 52597)

Gardenia erubescens Stapf \& Hutch., Senegal Kolda, J. De Wolf s.n. (Tw 51568), $2 \mathrm{~cm}-$ G. lucida Roxb., India Madhya Pradesh, Brila Institute Scientific Research s.n. (Tw 45503) - G. ternifolia Schumach. \& Thonn. subsp. goetzei (Stapf \& Hutch.) Verdc., Senegal Thies, A. Mariaux 1282 (Tw 41467) - G. ternifolia Schumach. \& Thonn. subsp. jovis-tonantis (Welw.) Verdc., Angola, R. Dechamps 1030 (Tw 28646) - G. tubifera Wall. ex Roxb., Congo(-Kinshasa), L. Meijer 59123 (Tw 18688)

Genipa americana L., Surinam, Stahel 379 (Tw 25580)

Gleasonia duidana Standl. var. duidana, Venezuela, Amazonas, B. Maguire et al. 27564 (Tw 36493)

Gonzalagunia rosea Standl., Panama, Calon, M. Nee 7088 (Tw 43021), $1.6 \mathrm{~cm}$

Gouldia terminalis (Hook. \& Arn.) Hillebr., Hawaii, A.B. Curtis H. 26 (Tw 26785)

Guettarda scabra (L.) Lam., Antilles Françaises, Guadeloupe, Beraud 1 (Tw 42429)

Gyrostipula foveolata (Capuron) J.-F.Leroy, Grande Comore, C.T.F.T. France Essai 386 (Tw 30834) 
Hamelia axillaris Sw., Cuba, between Baracoa and Maisi, R. Dechamps 12065 (Tw 48189), $0.9 \mathrm{~cm}-$ H. axillaris Sw., Cuba, Santiago de Cuba, Gran Piedra, R. Dechamps et al. 12359b (Tw 49828), 1.6 cm - H. patens Jacq., Brazil, Amazonas, B.A. Krukoff 5119 (Tw 34221); Florida, Forest Products Research Laboratory 12802 (Uw 17765) - H. ventricosa Sw., Jamaica, U.S. National Herb. Smithson. Inst. 6017 (Uw 8356)

Heinsia crinita (Afzel.) G.Taylor, Congo(-Kinshasa), J. Louis 515 (Tw 32872), 2.4 cm; Congo(-Kinshasa), Milambo, J. Claessens 238 (BR), $0.6 \mathrm{~cm}$

Hillia parasitica Jacq., Cuba, Granna, R. Dechamps 12414 (Tw 49892), $1 \mathrm{~cm}$

Holtonia myriantha (Standl.) Standl., Colombia, J. Cuatracasas 21625 (Tw 21625)

Hymenodictyon floribundum (Hochst. \& Steud.) Rob., Congo(-Kinshasa), Katanga, Malaisse $6916 \mathrm{~b}$ (Tw 23980) - H. orixense (Roxb.) Mabb., Thailand, Royal For. Depart. s.n. (Tw 18549)

Hypobathrum sp., Indonesia, Van Balgooy \& Van Setten 5466 (Uw 31825), $2.8 \mathrm{~cm}$

Isertia hypoleuca Benth., British Guyana, A.C. Smith 2517 (Tw 27353)

Kutchubaea neblinensis Steyerm., Venezuela, Amazonas, B. Maguire et al. 42084 (Tw 36604) - K. sericantha Standl., Venezuela, Amazonas, B. Maguire et al. 27882 (Tw 36283)

Ladenbergia lambertiana (A.Br. ex Mart.) Klotzsch, Venezuela, Amazonas, B. Maguire et al. 43668 (Tw 37044) - L. spec., Peru, Huanuco, TM 74 (Tw 20135)

Lamprothamnus zanguebaricus Hiern, Tanzania, Dar es Salaam to Morogoro, Welch 387 (BR), 0.6 $\mathrm{cm}$

Lindenia rivalis Benth., Mexico, Hansen \& Nee 1544 (Tw 29425), $1.8 \mathrm{~cm}$

Macbrideina peruviana Standl., Peru, Huanuco, Servicio Forestal TM-49 (Tw 25260)

Macrocnemum roseum (Ruiz \& Pav.) Wedd., Panama, Canal Zone, M. Nee 9417 (Tw 43118)

Malanea gabrielensis Müll.Arg., Venezuela, Amazonas, B. Maguire et al. 42888 (Tw 36935), $1 \mathrm{~cm}$

Massularia acuminata (G.Don) Bullock ex Hoyle, Congo(-Kinshasa), Kasai, R. Dechamps 32 (Tw 8294)

Mastixiodendron pachyclados (K.Schum.) Melch., New Guinea, Gov. For. Exp. St. 11586 (Tw 31087) - M. stoddardii Merr. \& L.M.Perry, Papua, Garo Garo, Department of Forest s.n. (Tw 22916)

Mitragyna inermis (Willd.) Kuntze, Cameroon, Fort-Lamy (Ndjamena), J. Jangoux 10020 (BR)

Morelia sp., Congo(-Kinshasa), C. Donis 2091 (Tw 32432)

Mussaenda arcuata Poir., Angola, Benguela, R. Dechamps 1065 (Tw 28290) - M. elegans Schumach. \& Thonn., Congo(-Kinshasa), Wagemans 2388 (Tw 41358), $2.5 \mathrm{~cm}$

Oldenlandia filifolia K.Krause, country unknown, Bos van Tabora, V. Trotha 61 (Uw 25954)

Oxyanthus speciosus DC. subsp. speciosus, Congo(-Kinshasa), Luzina, J. Lebrun 5410 (Tw 2512) O. unilocularis Hiern, Ivory Coast, P. Bamps 2334 (Tw 22972)

Pagameopsis maguirei Steyerm. subsp. neblinensis var. angustifolius Steyerm., Venezuela, T.F. Amazonas, Cerro de la Neblina, Maguire et al. 42129 (Tw 36619)

Palicourea alpina (Sw.) DC., Cuba, Granna, Pico Turquino, R. Dechamps 12424 (Tw 49893), $2.2 \mathrm{~cm}$ - P. crocea (Sw.) Schult., Venezuela, Amazonas, collector unknown (Tw 38180)

Pauridiantha dewevrei (De Wild. \& T.Durand) Bremek., Congo(-Kinshasa), Haut-Congo, J. Louis 2333 (Tw 33436)

Pausinystalia lane-poolei (Hutch.) Hutch. ex Lane-Poole, Liberia, Bassa, L. Cooper 278 (Tw 10397) - P. talbotii Wernham, Congo(-Kinshasa), J. Louis 2929 (Tw 34901), $1.8 \mathrm{~cm}$

Pentagonia macrophylla Benth., Panama, Canal Zone, 6 km west of Gamboa, M. Nee 7206 (Tw 43043)

Pentanopsis fragrans Rendle, origin unknown, C. Puff C. 821227-1/4 (Uw 30887)

Pentas lanceolata (Forssk.) Deflers, origin unknown, J. Lebrun 8151 (BR), $0.4 \mathrm{~cm}-$ P. nobilis S.Moore, Tanzania, Chunya, Mbagala, S. Bidgood et al. 2275 (BR) - P. schimperiana (A.Rich.) Vatke, Congo (-Kinshasa), J. Louis 4877 (Tw 35658), $1.3 \mathrm{~cm}$; Kivu, Goma-Sake, D. Van der Ben 97 (BR); Ethiopia, Menagesha State Forest, C. Puff 810920-1/2 (Uw 27081)

Placopoda virgata Balf. f., Socotra, Schweinfurth 43 (Uw 25955)

Platycarpum orinocense Humb. \& Bonpl. var. orinocense, Venezuela, Amazonas, B. Maguire et al. 41463 (Tw 36710)

Polysphaeria pedunculata K.Schum. ex De Wild.,Congo(-Kinshasa), Katanga, F. Malaisse 9605 (Tw 35156)

Porterandia cladantha Keay, Congo(-Kinshasa), J. Louis 2840 (Tw 34842), $2.1 \mathrm{~cm}$ 
Posoqueria latifolia (Rudge) Schult., Venezuela, Amazonas, B. Maguire et al. 28958 (Tw 36271) P. longiflora (Rudge) Schult., Venezuela, Amazonas, Maguire et al. 43611 (Tw 36965)

Psychotria sp., Brazil, Matto-Grosso, B.A. Krukoff 1512 (Tw 33914) - P. brachiata Sw., Cuba, Gramma, R. Dechamps 12432 (Tw 49906), 20 mm - P. cotejensis (Standl.) J.H.Kirkbr., Columbia, Prov. Choco, Cuatrecasas 17208 (Uw 25330) - P. greenwelliae Fosberg, Hawaii, W.L. Stern s.n. (Uw 10431) - P. nuda (Cham. \& Schltdl.) Wawra, Brazil, Clausen 64 (Uw 25972) - P. peduncularis (Salisb.) Steyerm., Yaunde, Zenker 788 (Uw 25973)

Randia sp., Brazil, Parana, Lindeman \& De Haas 1082 (Tw 35235)

Remijia sipapoensis Steyerm., Venezuela, Amazonas, B. Maguire et al. 28013 (Tw 36346)

Retiniphyllum laxiflorum (Benth.) M.E.Br., Venezuela, Amazonas, B. Maguire et al. 42229 (Tw 36424) - R. pauciflorum Kunth ex K.Krause, Venezuela, Amazonas, B. Maguire et al. 41892 (Tw 36476), $2 \mathrm{~cm}$

Rondeletia parviflora Poir., French Antilles, Guadeloupe, Rollet, C.T.F.T. 1164 (Tw 47657)

Rothmannia liebrechtsiana (De Wild. \& T.Durand) Keay, Congo(-Kinshasa), C. Donis 2300 (Tw 32557) - R. longiflora Salisb., Congo (-Kinshasa), C. Donis 2075 (Tw 32410), $2.8 \mathrm{~cm}$

Rubia fruticosa Aiton, Canary Islands, Lanzarote, Lindeman 7117 (Uw 30436), $2 \mathrm{~cm}$

Rudgea cornigera Bremek., Surinam, Lindeman 4582 (Uw 3177), $3 \mathrm{~cm}-R$. hostmanniana Benth. subsp. hostmanniana, Maas et al. M 5884 (Uw 27401), $1.5 \mathrm{~cm}-$ R. lanceolata (Cham.) Benth., Lindeman \& De Haas 2036 (Uw 13472), $0.9 \mathrm{~cm}$; origin \& collector unknown (Uw 13605)

Sabicea calycina Benth., Congo(-Kinshasa), Kouilou, R. Dechamps 13043 (Tw 49031) - S. villosa Roem. \& Schult., Panama, Navy Reservation, North of Gamboa, A. Robyns 65-49 (BR)

Saprosma foetens (Wight) K.Schum. subsp. ceylanicum (Gardner) M.G.Gangop. \& Chakrab., India, Cardamom Hills, C.E. Ridsdale 175 (L)

Schradera brevipes Steyerm., Venezuela, Amazonas, Maguire et al. 27895 (holotype) (Tw 36563) S. hillifolia Steyerm., Venezuela, Amazonas, Maguire et al. 43316 (Tw 36978), $1.3 \mathrm{~cm}$

Schumanniophyton hirsutum (Hiern) Good, Congo (-Kinshasa), C. Donis 2116 (Tw 32450) - S. magnificum (K.Schum.) Harms, Congo (-Kinshasa), R. Dechamps 8047 (Tw 40372)

Sericanthe leonardii (N.Hallé) Robbr. subsp. venosa Robbr., Rwanda, P. Auquier 3531 (Tw 28730)

Sherbournia bignoniifolia (Welw.) Hua, Congo (-Kinshasa), Schikawa et al. 281 (Tw 45434), $0.5 \mathrm{~cm}$

Simira rubescens (Benth.) Bremek. ex Steyerm., Brazil, B.A. Krukoff 5436 (Tw 34358) - S. tinctoria Aubl., Peru, Loreto, Lower Huallaga, L. Williams 4132 (Tw 46699)

Spermacoce ["Borreria macrocephala Standl. \& Steyerm."], Venezuela, Amazonas, B. Maguire et al. 41668 (Tw 36238), $0.7 \mathrm{~cm}-$ S. suaveolens (G.Mey.) Kuntze, Venezuela, Amazonas, B. Maguire et al. 42698 (Tw 36671), $2 \mathrm{~cm}-$ S. verticillata L., Morro do Chapen-Bonito, km 12, Cavalcanti et al. 358 (Uw 33690)

Spermadictyon suaveolens Roxb., India, Mussoorie, Van Steenis 21125 (Uw 20406)

Stachyarrhena acuminata Standl., Brazil, Amapa, collector unknown (Tw 37873)

Stenostomum bifurcatum Griseb., Jamaica, R.B. Miller s.n. (Tw 29241)

Tarenna laurentii (De Wild.) J.G.Garcia, Congo (-Kinshasa), J. Louis 1546 (Tw 33224), $1.5 \mathrm{~cm}$

Timonius sp., Indonesia, Service Forest. 12465 (Tw 23795)

Tocoyena foetida Poepp. \& Endl., Bolivia, Santa Cruz, Nee 37033 (Tw 51279), 2.5 cm; Peru, L.Lebacq 1302 (Tw 16302) - T. pittieri (Standl.) Standl., Colombia, J. Cuatrecasas 17264 (Tw 39617) T. williamsii Standl., Peru, L. Lebacq s.n. (Tw 16034)

Tricalysia coriacea (Benth.) Hiern, East Africa, Schlieben \& Reinbek 1509 (Uw 15491) - T. crepiniana De Wild. \& T.Durand, Congo (-Kinshasa), Cuvette Centrale, J. Louis 2092 (Tw 33384) - T. elliotii (K.Schum.) Hutch. \& Dalziel, Congo (-Kinshasa), C. Donis 2019 (Tw 32381) - T. pallens Hiern, Congo(-Kinshasa), J. Louis 1420 (Tw 33157), 2.7 cm; Congo(-Kinshasa), Katanga, F. Malaisse 9662 (Tw 35130)

Uncaria africana G.Don. var. xerophila E.M.A.Petit, Congo(-Kinshasa), J. Louis 6105 (Tw 35857), $1 \mathrm{~cm}-$ U. donisii E.M.A.Petit, Congo (-Kinshasa), C. Donis 1968 (Tw 32399), $2.3 \mathrm{~cm}$

Warszewiczia coccinea (Vahl) Klotzsch, Venezuela, Amazonas, B. Maguire et al. 28072 (Tw 36306)

Wendlandia amocana Cowan, Pakistan, Majumdar \& Islam 107 (Tw 25264)

Wiegmannia sp., Hawaii, Kauai, Maryland, Stern \& Herbst 524 (Uw 18607), $1 \mathrm{~cm}$ 


\section{General description of the wood anatomy of the Rubiaceae}

This section summarises briefly all wood anatomical features of the family.

\section{Growth rings}

Growth rings are usually present, but often indistinct. An examination of the Tw wood sections showed distinct growth rings in circa $25 \%$ of the samples investigated (Beeckman \& Jansen 1995). They are formed by changes in fibre walls as well as by differences in the vessel density, vessel diameter and/or marginal parenchyma (Fig. $5,34)$.

\section{Vessels}

Porosity - The wood is nearly always diffuse-porous, only occasionally (semi-) ring-porous.

Vessel arrangement - Vessels are usually arranged in a weak radial pattern. Vessels are often in irregular tangential chains or broken concentric bands in representatives of the tribe Henriquezieae (especially Platycarpum), and in tangential or diagonal chains in Genipa, Ladenbergia, Placopoda (Fig. 34), Rubia, and Triainolepis.

Vessel groupings - Vessels are most frequently solitary with radial multiples of 2-3 vessels. In some genera they are exclusively solitary or nearly so (Fig. 16-21, 30,31 ). In other genera the vessels are mainly in short radial multiples of $2-4$ or with multiples in more than 4 cells (Fig. 11, 22-24, 35).

Solitary vessel outline - Vessel outline is circular or oval (e.g. Fig. 17), but also angular in numerous taxa (e.g. Fig. 23).

Perforation plates - Simple perforation plates are the most common type (Fig. 45, 46); reticular, scalariform or malformed plates are occasionally present in most groups of the family. Scalariform perforation plates are common in few representatives of Chazaliella, Coprosma (Fig. 37), Crucianella (Fig. 40), and Trichostachys. In some genera more than one perforation is found in a single perforation plate.

Intervessel pits - They are generally alternate, sometimes polygonal (e.g. Coussarea), minute $(\leq 4 \mu \mathrm{m})$ or small $(4-7 \mu \mathrm{m})$, and only rarely more than $7 \mu \mathrm{m}$ (Fig. 41$)$.

Vestured pits - Vestures are constantly present, but sometimes difficult to determine by LM (Fig. 41, 42, 44). In few species, vestured pits are restricted to pits of small tracheary elements or fibre pits, so that non-vestured pits can be found in wider vessels (e.g. Fig. 43).

Vessel-ray pitting - They most frequently show distinct pit borders and are similar to intervessel pits in size and shape throughout the ray cell. Genera in which vesselray pitting shows reduced pit borders to simple pits are found in Belonophora, Calycophyllum, Ferdinandusa, Galiniera, Hamiltonia, Joosia, Platycarpum, Psychotria, Rutidea, Schradera, and Spermadictyon.

Helical thickenings - Helical thickenings in tracheary elements are reported in only few genera: Anthospermum, Coprosma, Emmenopterys, Genipa, and Rubia.

Tangential diameter of vessel lumina - Vessels are typically narrow (50-100 $\mu \mathrm{m})$ or very narrow $(<50 \mu \mathrm{m}$; Fig. 15, 30), but medium-sized $(100-200 \mu \mathrm{m})$ in some genera (especially large trees and vines), and rarely very wide (>200 $\mu \mathrm{m}$ in Henriquezieae and Paederia). 

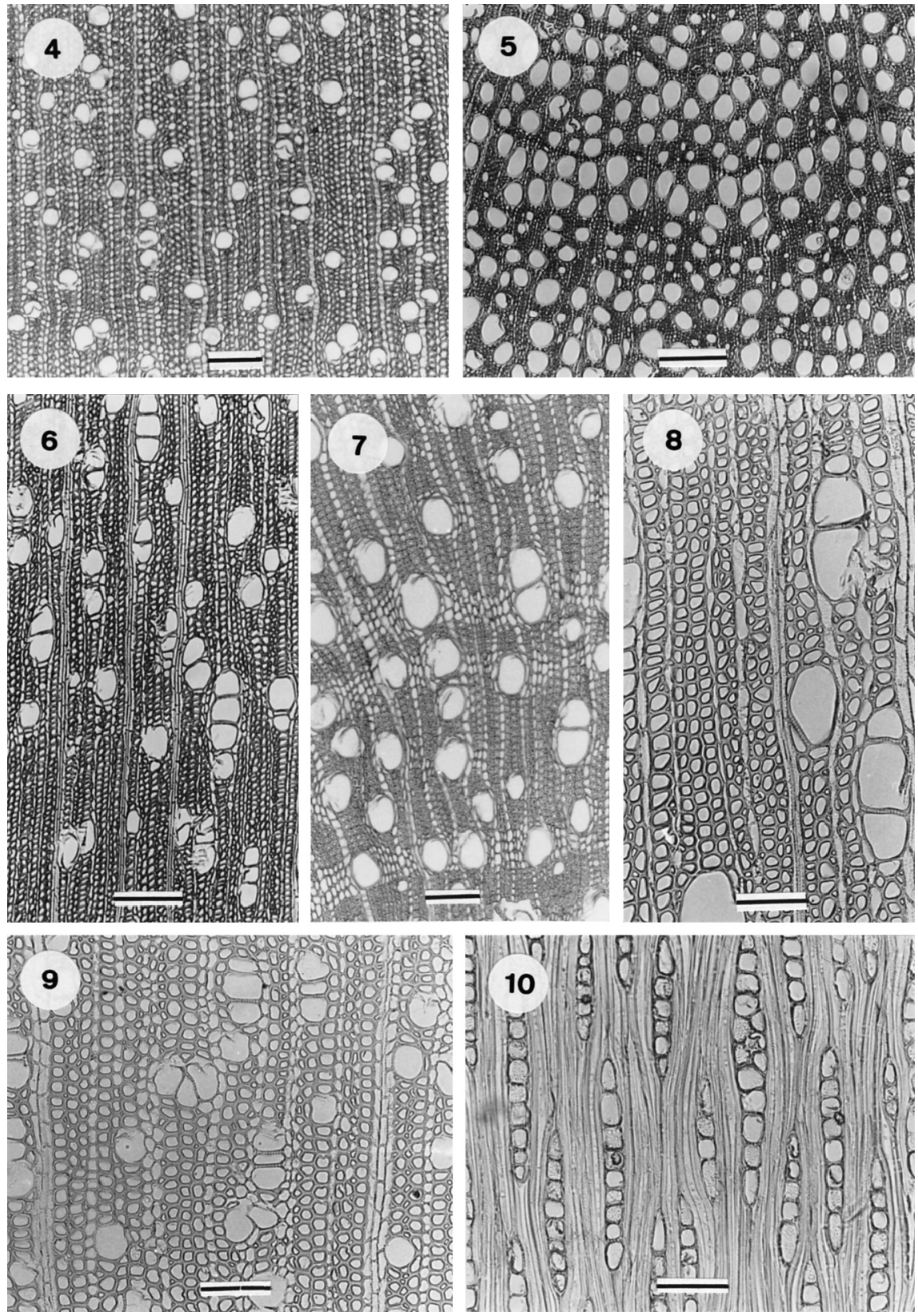

Fig. 4-10. Transverse (4-9) and tangential (10) wood sections of Cinchonoideae s.l. - 4: Vessels mainly solitary and axial parenchyma diffuse in Wendlandia amocana. - 5: Semi-ring-porous wood and indistinct growth rings in Chiococca alba. - 6: Stenostomum bifurcatum. - 7: Solitary vessels and axial parenchyma bands in Malanea gabrielensis. - 8: Wood type II in Stenostomum bifurcatum. - 9: Hamelia axillaris (Tw 48189) with wood type II. - 10: Low, uniseriate rays in Platycarpum orinocense. - Scale bar = $200 \mu \mathrm{m}$ in Fig. 4-7; $100 \mu \mathrm{m}$ in Fig. 8-10. 

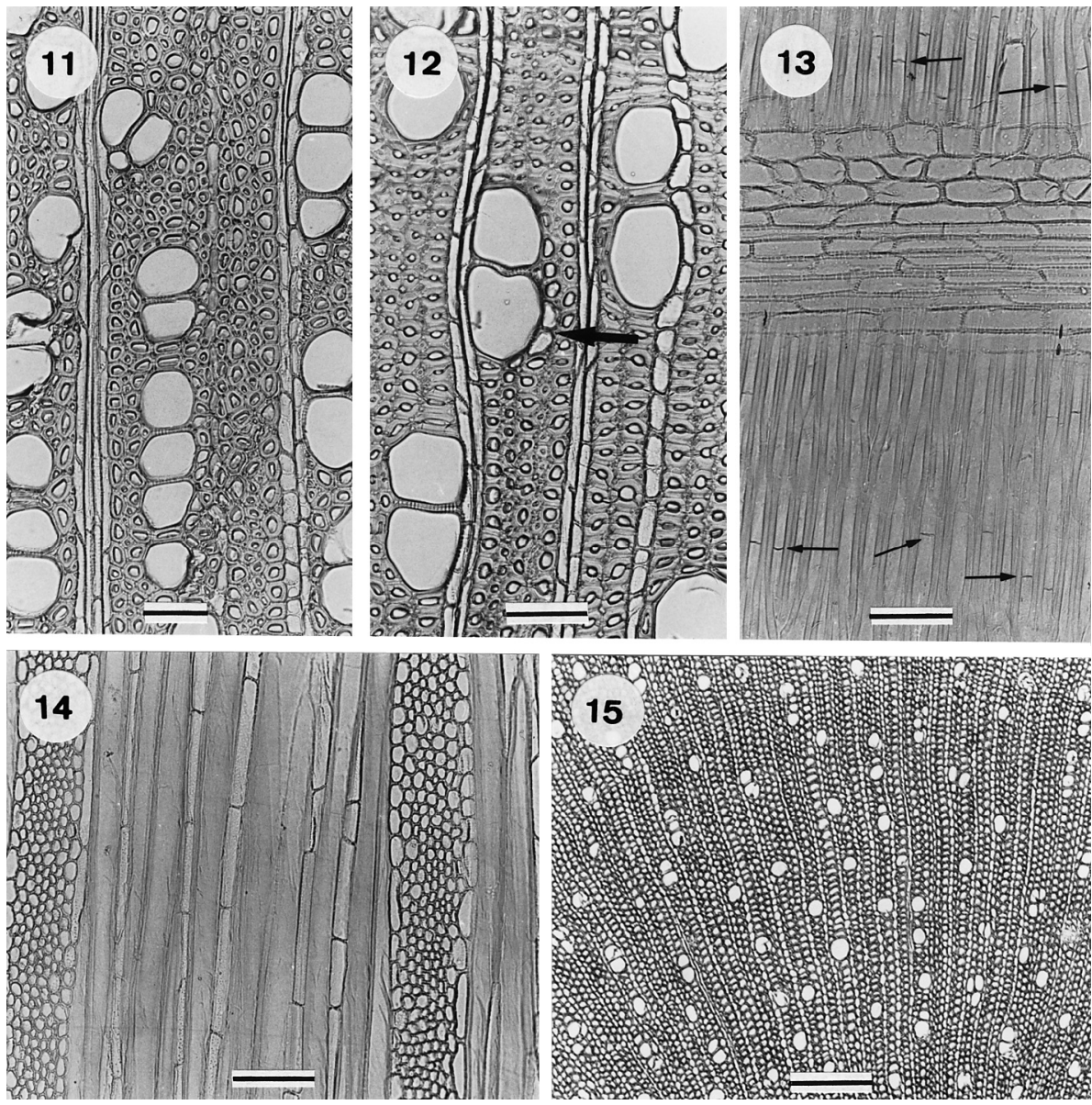

Fig. 11-15. Transverse $(11,12,15)$, tangential (14) and radial (13) wood sections of Ixoroideae s. 1. with wood type II. - 11: Vessels in short radial multiples and absence of axial parenchyma in Simira rubescens. - 12: Axial parenchyma rarely paratracheal (arrow) in Mastixiodendron pachyclados. - 13: Septate (arrows) libriform fibres in Chimarrhis brevipes. - 14: High, multiseriate rays with sheath cells in Elaeagia utilis. -15 : Heinsia crinita with thin-walled fibres. - Scale bar $=200 \mu \mathrm{m}$ in Fig. 11, 15; $100 \mu \mathrm{m}$ in Fig. $12-14$.

Vessels per square millimetre - The vessel density varies from numerous (40-100 vessels $/ \mathrm{mm}$ ) to very numerous (>100 vessels $/ \mathrm{mm}$ ). Occasionally less than 40 vessels/mm are found.

Mean vessel element length - Vessel elements are usually of medium length (350$800 \mu \mathrm{m})$, but sometimes very long (> $800 \mu \mathrm{m})$.

Tyloses and deposits in vessels - Tyloses are generally wanting, but they are found in several genera. Gum deposits are common to abundant. 

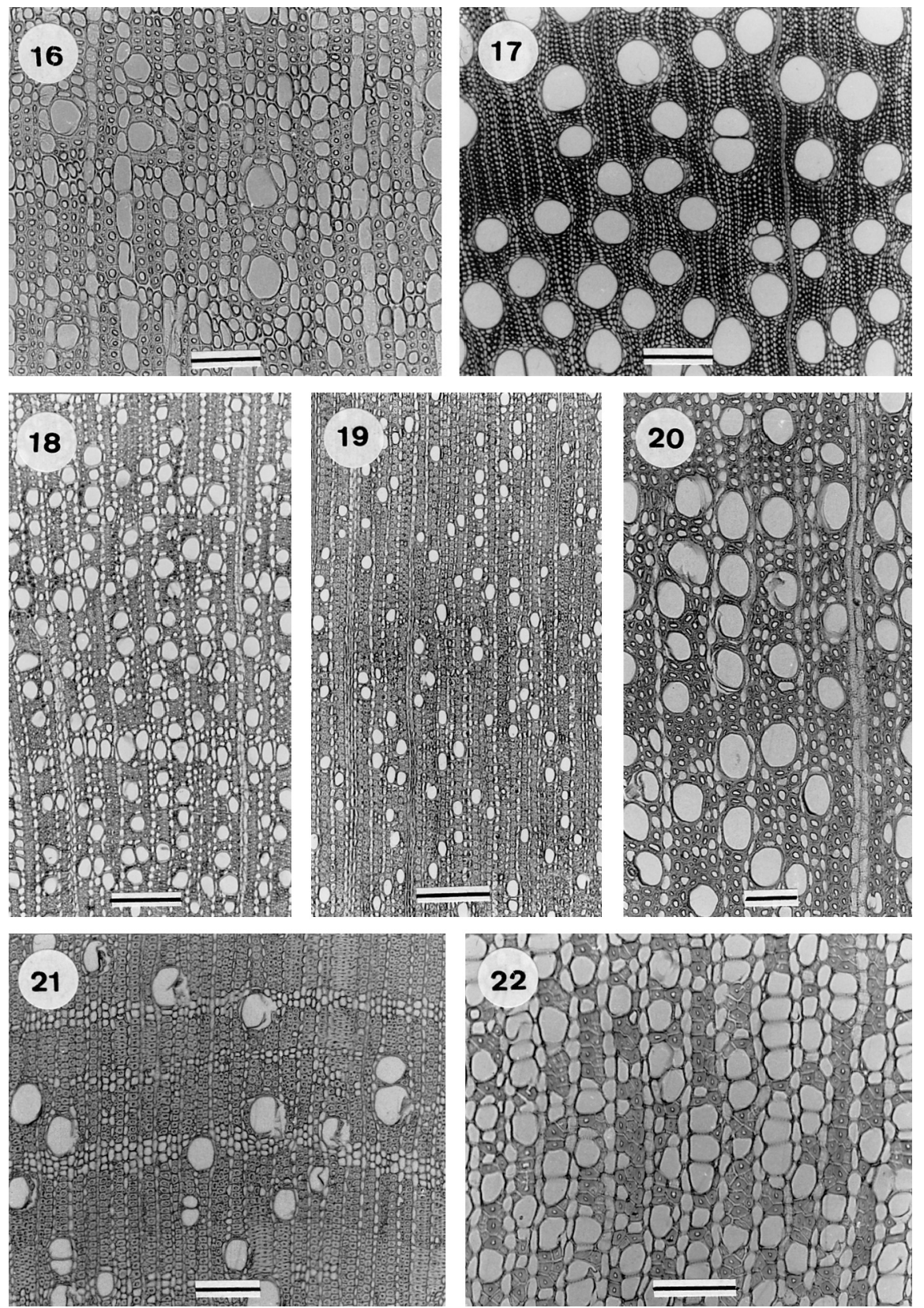

Fig. 16-22. Transverse wood sections of core Ixoroideae (16-21) and Posoqueria (22). - 16: Axial parenchyma bands and solitary vessels in Retiniphyllum pauciflorum. - 17: Solitary, wide vessels in Aoranthe castaneofulva. - 18: Wood type I in Alberta humblotii. - 19: Wood type I in Massularia acuminata. - 20: Wood type I in Aidia cochinchinensis. - 21: Duroia aquatica with axial parenchyma in narrow lines or bands up to 3 cells wide. - 22: Vessels mainly in short radial multiples in Posoqueria longiflora. - Scale bar $=100 \mu \mathrm{m}$ in Fig. 16, 18, 22; $200 \mu \mathrm{m}$ in Fig. 17, 19-21. 

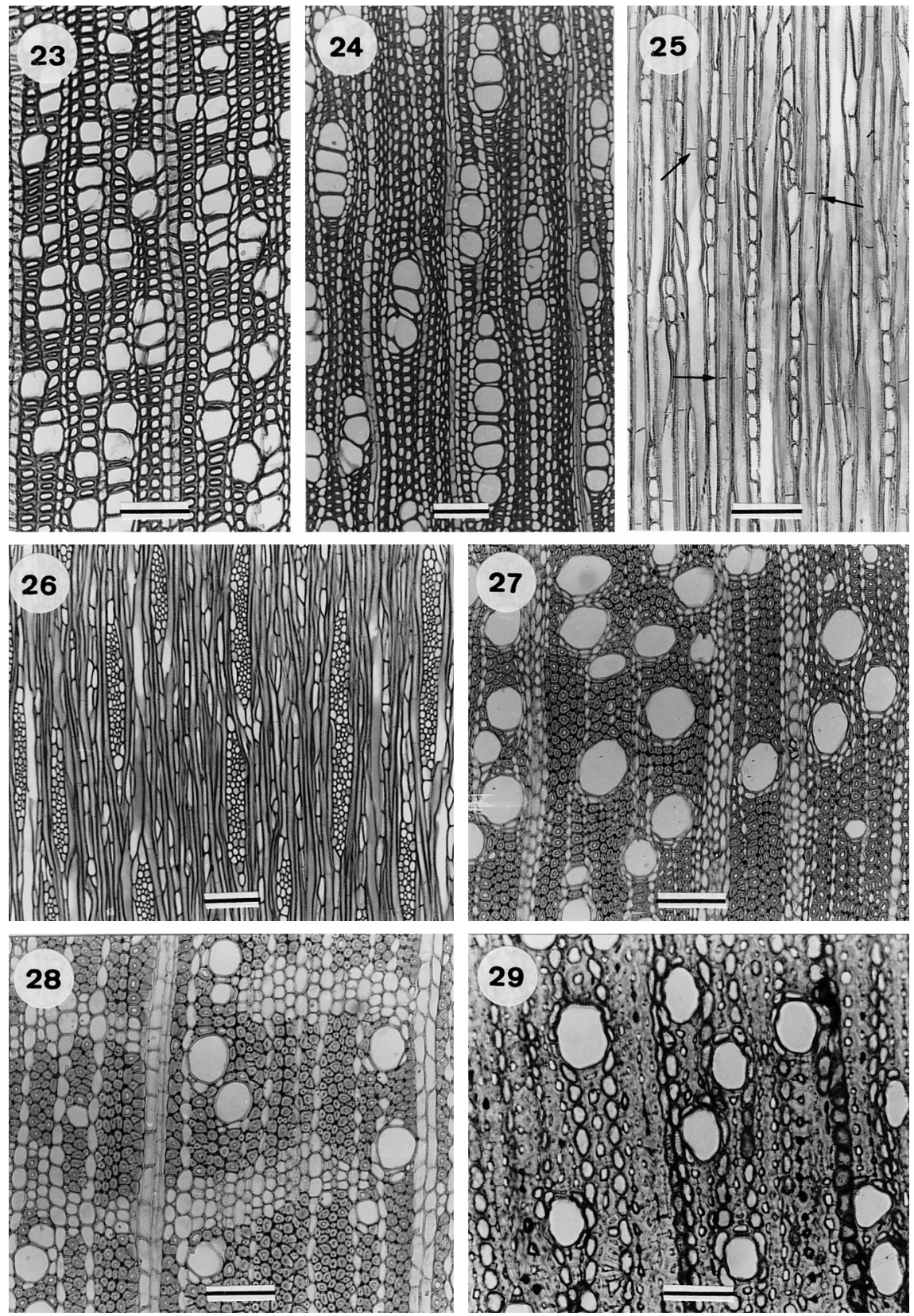

Fig. 23-29. Transverse $(23,24,27-29)$ and tangential $(25,26)$ wood sections of Rubioideae. -23 : Wood type II in Psychotria cotejensis. - 24: Wood type II in Psychotria chionantha. - 25: Septate (arrows) fibres and 1-2-seriate rays in Rudgea lanceolata. - 26: Uniseriate and multiseriate rays in Psychotria green-welliae. - 27: Scanty paratracheal parenchyma in Schradera brevipes. - 28: Axial parenchyma bands and solitary vessels in Colletoecema dewevrei. -29 . Solitary vessels and scanty paratracheal parenchyma in Pagameopsis maguirei. - Scale bar $=100 \mu \mathrm{m}$ in Fig. 23, 25, 27-29; $200 \mu \mathrm{m}$ in Fig. 24, 26. 

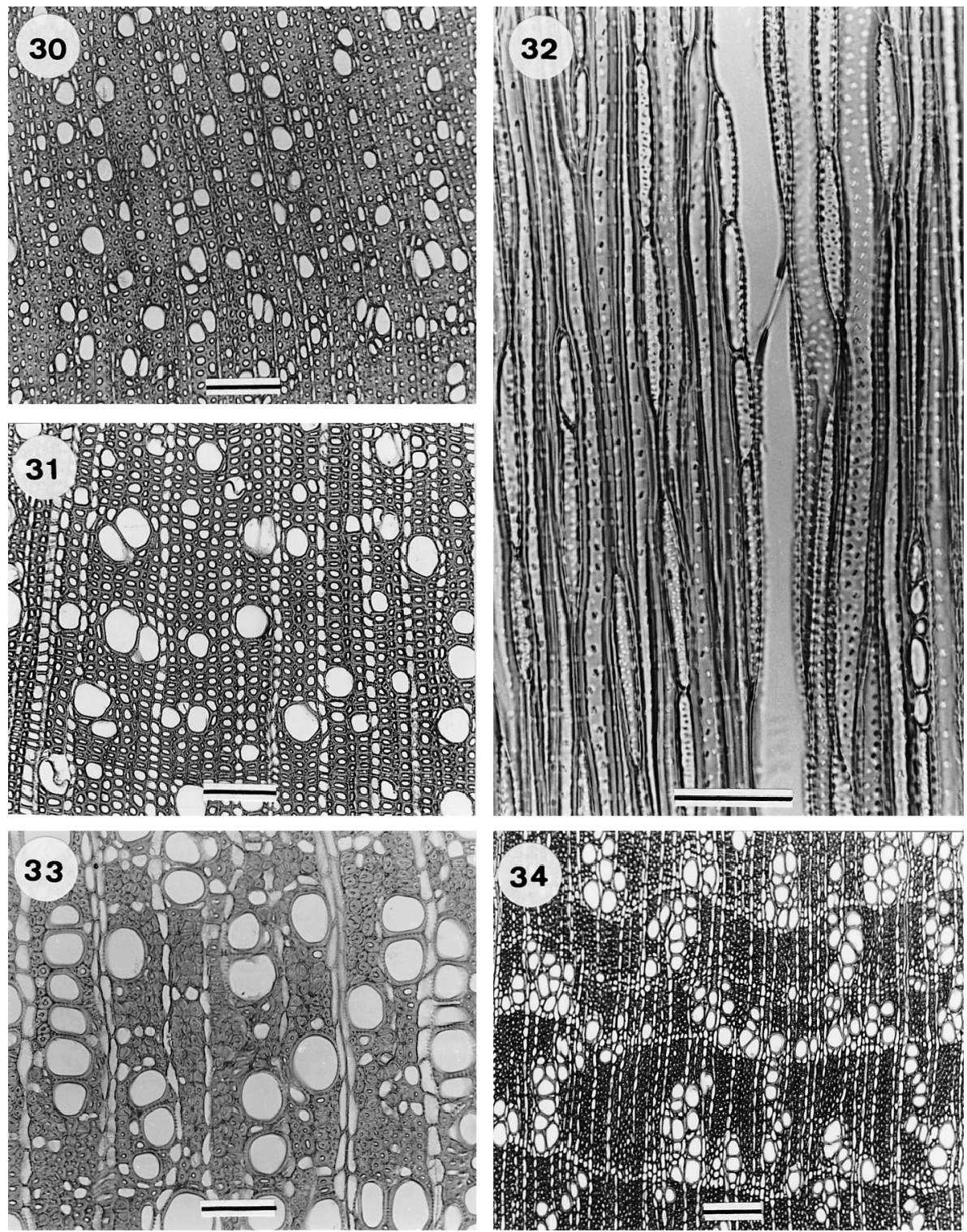

Fig. 30-34. Transverse (30, 31, 33, 34) and tangential (32) wood sections of Rubioideae. - 30: Spermacoce verticillata. - 31: Pentas schimperiana. - 32. Fibre-tracheids with bordered pits at left, vessel elements and fibriform vessel elements or tracheids at right in Spermacoce verticillata. - 33: Diffuse axial parenchyma in Oldenlandia filifolia. - 30: Growth rings and radial/tangential vessel arrangement in Placopoda virgata. - Scale bar $=100 \mu \mathrm{m}$ in Fig. 30, 31, 33; $50 \mu \mathrm{m}$ in Fig. 32; $200 \mu \mathrm{m}$ in Fig. 34. 

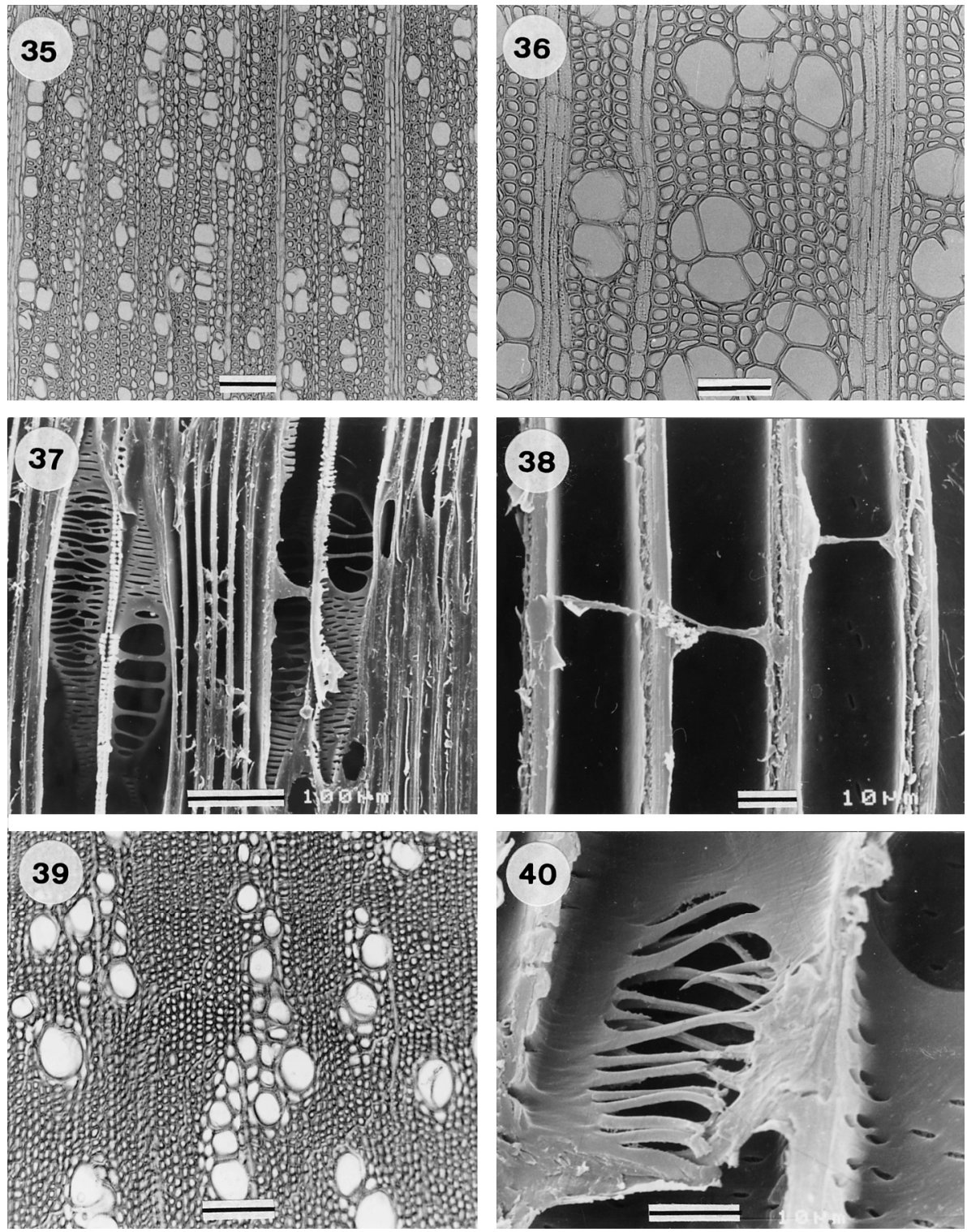

Fig. 35-40. Transverse $(35,36,39)$ and longitudinal $(37,38,40)$ wood sections of Anthospermeae and Rubieae (Rubioideae). - 35: Coprosma rhynchocarpa. - 36: Vessels in clusters or radial multiples in Coprosma ochracea. - 37: Scalariform perforation plates in Coprosma ochracea. - 38: Detail of septate libriform fibres in Coprosma ochracea. - 39: Radial / tangential vessel arrangement and paratracheal parenchyma in Rubia fruticosa. - 40: Scalariform perforation plate in Crucianella maritima. - Scale bar $=200 \mu \mathrm{m}$ in Fig. 35; $100 \mu \mathrm{m}$ in Fig. 36, 37, 39; $10 \mu \mathrm{m}$ in Fig. 38, 40. 

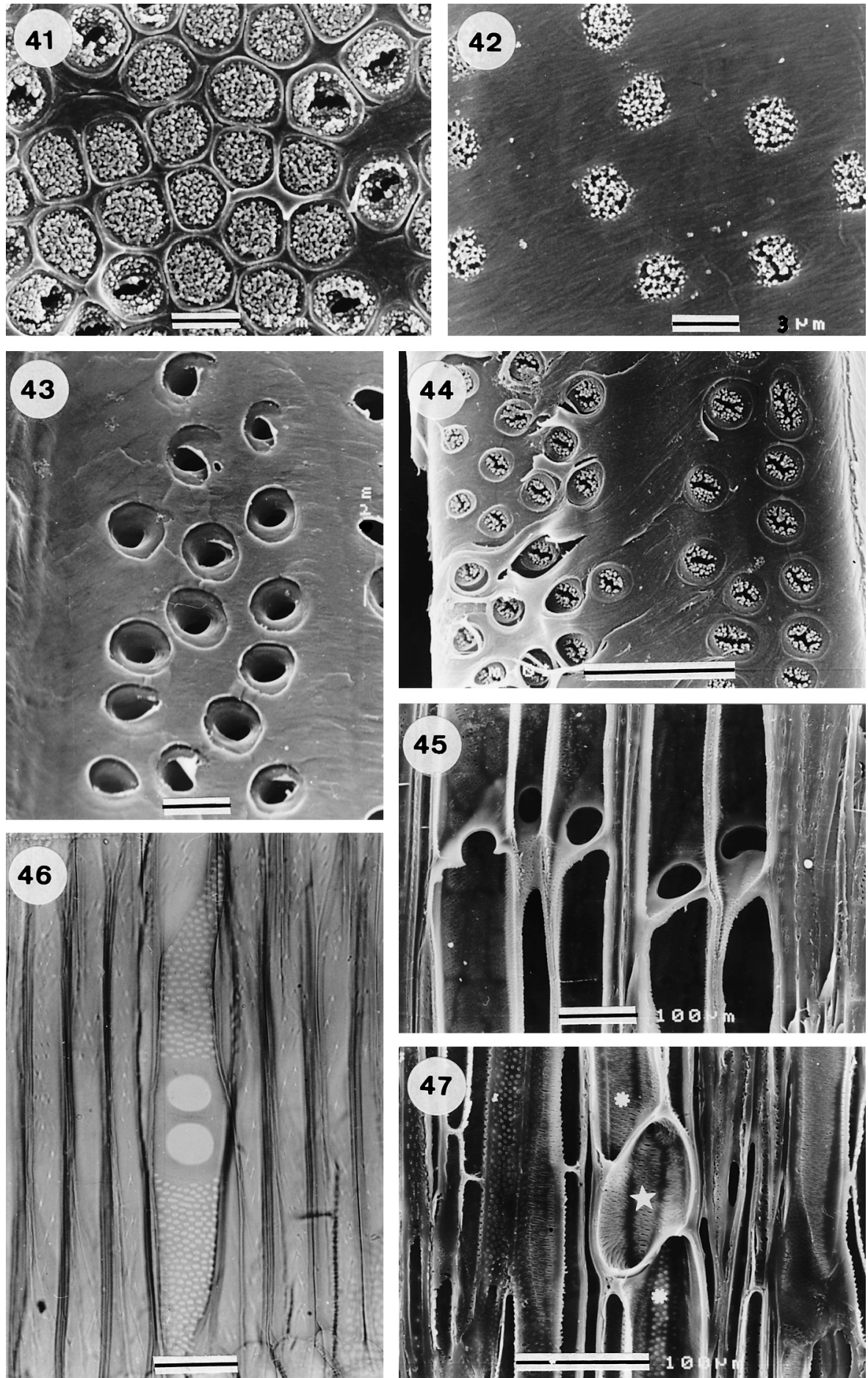


\section{Tracheids and fibres}

Vascular/vasicentric tracheids - Tracheids are present in numerous genera.

Ground tissue fibres - Fibres show simple, minutely $(<3 \mu \mathrm{m})$ to distinctly $(\geq 3 \mu \mathrm{m})$ bordered pits (e.g. Fig. 32).

Septate fibres - They are present in about $25 \%$ of the genera (Fig. 13, 25, 38) and mainly restricted to the following tribes: Argostemmateae, Calycophylleae, Condamineeae, Coussareeae, Hamelieae, Hillieae, Hippotideae, Mussaendeae, Paederieae, Psychotrieae, and Simireae. The feature is also present in Damnacanthus and a few genera of the Anthospermeae and Guettardeae.

Fibre wall thickness - Fibres are generally thin- to thick-walled. Very thick-walled fibres (fibre lumina almost completely closed) occur in Bothriospora, Mitragyna, Henriquezieae, and Pertusadina.

Mean fibre lengths - Fibres are usually of medium length $(900-1600 \mu \mathrm{m})$, but sometimes much shorter $(<900 \mu \mathrm{m})$ or longer $(>1600 \mu \mathrm{m})$.

\section{Axial parenchyma}

Axial parenchyma absent or extremely rare - Absence of axial parenchyma is characteristic of species with septate fibres, although there are few exceptions (Fig. 6, 8, $9,23,24)$.

Apotracheal axial parenchyma - The apotracheal parenchyma is usually present as diffuse or diffuse-in-aggregates, with tendencies to form short uniseriate lines (Fig. 4, 20, 33).

Paratracheal axial parenchyma - Scanty paratracheal parenchyma is present in few genera with either septate or non-septate fibres (Fig. 12, 27, 29, 36, 39). Aliform and confluent parenchyma is reported in Henriquezieae, and only occasionally in Jackiopsis, Retiniphyllum, and Timonius.

Banded parenchyma - This parenchyma type is uncommon in Rubiaceae but present in Colletoecema (Fig. 28), Craterispermeae, Gaertnereae, Ixoreae, Retiniphylleae (Fig. 16), Schradera, several representatives of the Morindeae, the Alibertia group (Gardenieae, Fig. 21), and few Guettardeae (Bobea, Malanea: Fig. 7, Timonius).

Axial parenchyma cell type/strand length - Axial parenchyma strands are most commonly composed of 8 cells or more, sometimes of 4 cells. Short parenchyma strands are reported in Paederieae and Anthospermeae.

Rays

Ray width - Generally narrow, up to 2-3-seriate and with long uniseriate margins. Exclusively uniseriate or with only occasional biseriate parts in several genera (Fig. 10) and up to 8-10 cells wide in Capirona, Chimarrhis, Coprosma, Coussarea, Elaea-

Fig. 41-47. SEM-photographs (41-45, 47) and LM-photograph (46) of Rubiaceae. - 41: Vestured outer pit apertures of vessel element in Macbrideina peruviana. - 42: Vestured inner pit apertures of vessel element in Gardenia tubifera. - 43: Non-vestured outer pit apertures of vessel element in Psychotria brachiata. - 44: Vestures near outer pit aperture of vessel element in Aulacocalyx tal-botii. - 45: Simple perforation plates in Psychotria spec. - 46: Two simple vessel perforations in Psychotria nuda. - 47: Per-forated ray cell (star) and two vessel elements (indicated by round stars) in Chassalia bojeri. - Scale bar $=3 \mu \mathrm{m}$ in Fig. 41, 42, 43; $10 \mu \mathrm{m}$ in Fig. 44; $100 \mu \mathrm{m}$ in Fig. 45, 47; $50 \mu \mathrm{m}$ in Fig. 46. 

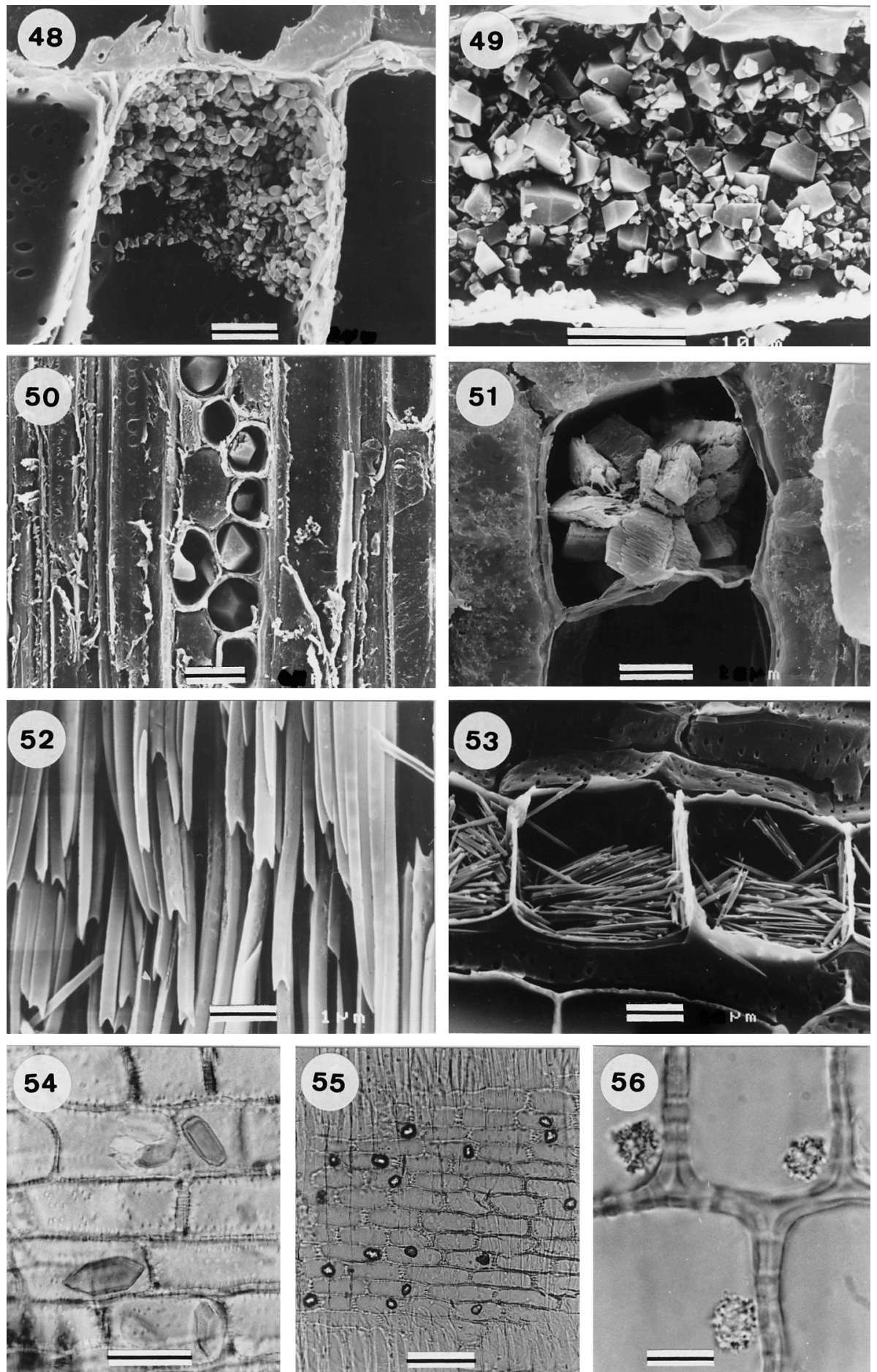
gia (Fig. 14), Faramea, Paederia, Saprosma, and Schradera. Vertically fused rays are very common.

Aggregate rays - Aggregate rays are only reported in Paederia.

Ray height - Rays are usually very high, more than $1 \mathrm{~mm}$ and often joined vertically. Rays much lower than $1 \mathrm{~mm}$ occur in Henriquezieae, Rubieae, and representatives of Anthospermeae and Paederieae.

Rays of two distinct sizes - Rays are frequently of 2 distinct sizes (uniseriate and multiseriate) or appearing so due to the numerous uniseriate rays or long uniseriate margins of the multiseriate rays (Fig. 26).

Cellular composition of rays - Heterogeneous rays are most common, with high ray margins of upright/square cells. Rays entirely composed of upright/square cells or rays with only 1 or 2 marginal rows of upright/square cells are also widespread. They correspond with Kribs' heterogeneous ray types I, II and III. Rays that are 4 or more cells wide are usually less markedly heterogeneous: the greater part of the ray is composed of procumbent cells and generally with less than 4 marginal rows of square to upright cells.

Sheath cells - These cells are common in rays that are $\geq 4$ cells wide. Upright ray cells form a complete to incomplete sheath around the procumbent cells of the multiseriate rays (Fig. 14).

Tile cells - Tile cells are lacking.

Perforated ray cells - Vessel-ray perforations are widespread in the family (Fig. 47). The perforations are simple, scalariform, reticulate or irregular, and sometimes vestured.

Disjunctive ray parenchyma cell walls - Disjunctive elements are common in several tribes of the family, especially in the tribes Gardenieae, Coffeeae and Pavetteae.

Rays per millimetre - In about $70 \%$ of the genera there are more than 12 rays per $\mathrm{mm}$. They frequently make up a very appreciable volume of the wood. Sometimes 20 or more rays per mm occur.

\section{Storied structure}

Storied structure is only reported in Galium (Rubieae) in which secondary woodiness is most likely.

\section{Secretory elements and cambial variants}

Secretory elements are lacking in the family. Cambial variants, in particular axes with furrowed or lobed xylem, are only reported in Atractogyne and Chiococca.

Fig. 48-56. Mineral inclusions in Rubiaceae. - 48: Crystal sand in ray cell in Malanea gabrielensis. 49: Crystal sand in ray cell in Simira rubescens. - 50: Prismatic crystals in ray cells in Aulacocalyx lujae. - 51: Druse in pith parenchyma cell in Doricera trilocularis. - 52: Detail of twin raphides with dovetailed ends in Cosmibuena grandiflora. - 53: Raphides in pith parenchyma in Pauridiantha dewevrei. 54: Elongate crystals in ray cells in Rondeletia parviflora. - 55: Silica bodies in ray cells in Platycarpum orinocense. - 56: Small mineral inclusions in ray cells (possibly silica bodies) in Posoqueria latifolia. Scale bar $=10 \mu \mathrm{m}$ in Fig. 48, 49, 52; $20 \mu \mathrm{m}$ in Fig. 50, 51, 53; $30 \mu \mathrm{m}$ in Fig. 56; $50 \mu \mathrm{m}$ in Fig. 54; $100 \mu \mathrm{m}$ in Fig. 55. 


\section{Mineral inclusions}

Raphides - Bundles of needle-shaped crystals are frequently found in representatives of the Rubioideae (Fig. 53), but also in the Hillieae and Hamelieae (Cinchonoideae, Fig. 52). They occur in axial parenchyma or ray parenchyma, sometimes in elongated sacs.

Prismatic crystals - Solitary and prismatic crystals having an octahedral or rhombic shape are abundantly present in ray cells of the Coffeeae, Gardenieae (Fig. 50) and Octotropideae. They are most frequently found in upright/square ray cells. Prismatic crystals also occur in chambered axial parenchyma cells of Homollea, Nichallea, Oldenlandia, Rondeletia (Fig. 54), Tarenna, and Timonius.

Druses - Druses are not found in secondary xylem, but they are abundantly present in pith parenchyma, secondary phloem or leaf tissues of several taxa (Fig. 51).

Styloids - This crystal type is rare in the Rubiaceae. Styloids are observed in Captaincookia, Cosmocalyx, Ixora, Versteegia and a single species of Morinda.

Crystal sand - Crystal sand is common in parenchyma cells (mostly ray cells) of numerous Ixoroideae s. 1. (Hippotideae, Calycophylleae, Simireae: Fig. 49, Condamineeae, Mussaendeae) and to a lesser extent in wood of the Cinchonoideae (Cinchoneae, Chiococceae, Guettardeae: Fig. 48, Naucleeae).

Silica - Silica bodies are only reported in the genera Hallea, Henriquezia, Mitragyna, and Platycarpum (Fig. 55). The inclusions in Posoqueria latifolia (Fig. 56) are suggested to be small silica bodies, but verification is needed.

\section{Wood types}

Based on a series of wood anatomical studies in the 1970s, Koek-Noorman (1977) concluded that there are two main types of secondary xylem in the Rubiaceae. Earlier findings of Koek-Noorman and Hogeweg (1974) and Hogeweg and Koek-Noorman (1975) not only stressed the taxonomic significance of fibre type differences (definitions following Reinders 1935), but also, on the basis of numerical analyses, pointed to a strong correlation between fibre type and other wood anatomical features within the Rubiaceae. The character complexes she distinguished were categorised in type I showing fibre-tracheids, while libriform fibres characterise type II. The distinction between the two types is given in Table 2 .

Table 2. Rubiaceous wood types. See text for further explanation.

\section{Type I}

Fibre-tracheids

Axial parenchyma apotracheal: diffuse, diffuse-in-aggregates or banded

Vessels mainly solitary

Narrow rays with long uniseriate margins

\section{Type II}

Septate libriform fibres

Axial parenchyma absent or scanty paratracheal

Vessels in short radial multiples (2-4 or more) and solitary

Rays wider, with few rows of upright / square ray cells 
We support the taxonomic significance of these two wood types because the distribution is largely in accordance with recent phylogenetic hypotheses of the family. However, exceptions to the general homogeneity at the generic and tribal level occur, for instance in the tribe Guettardeae in Robbrecht's $(1988,1994)$ delimitation. Coprosma is also very heterogeneous with respect to its wood anatomy. Carlquist (1992) even suggested that the diversity within this single genus contradicts the frequently cited homogeneity of the rubiaceous wood structure. We suggest that the wood anatomical variation in Coprosma can be explained by paedomorphic features and environmental influences (see below). The combination of the two wood types in one genus or tribe indeed puts doubt on the taxonomic delimitation of the group or raises the question whether the material studied is correctly identified. However, environmental considerations and geographical distribution should also be taken into account when interpreting the anatomical varation of the wood. Hence, variation in quantitative features or the distribution of axial parenchyma can in some instances be explained by environmental influences or habit (e.g. lianescent habit in Schradera, Morinda, Paederia).

\section{Wood anatomy and the classification of the Rubiaceae}

This section summarises the taxonomic distribution of wood features in the Rubiaceae (Tables 3-6; Fig. 57-65) and discusses the wood anatomical variation with reference to systematic coherence and affinities of tribes and genera.

\section{Subfamily Cinchonoideae s.str. (Fig. 57-59; Table 3)}

Wood type I characterises most tribes of this subfamily, namely Chiococceae, the Portlandia group of the Catesbaeeae, Isertieae, Corynanthe group, Naucleeae, Cephalantheae, Henriquezieae, and Rondeletieae (Fig. 57). On the other hand, wood type II is found at least in three clades: 1) Hamelieae, Hillieae, 2) several Guettardeae, and 3) Cinchoneae.

The morphological delimitation of the tribe Rondeletieae according to Delprete (1999) is summarised in Table 1 and compared to the molecular results of Rova (1999). Based on trnL-F and rps 16 data the latter author suggested that the circumscription of the Rondeletieae must be significantly narrowed. He therefore proposed to restrict the tribe to nine genera and included some other genera tentatively. While the two wood types are present in circumscriptions of the Rondeletieae according to Robbrecht (1988, 1994) and Delprete (1999), it is most interesting to find a much greater homogeneity in the wood structure when we follow the delimitation based on molecular sequence data. The secondary xylem of the Rondeletieae sensu Rova (1999) appears to be characterised by wood type I and the following genera that show wood type II need to be excluded from the Rondeletieae: Bathysa, Elaeagia, Macbrideina, Simira, and Warszewiczia. These are all included in the large complex of Calycophylleae, Condamineeae, Simireae and Hippotideae (Ixoroideae). Hence, the wood anatomy shows major differences between the Rondeletieae sensu Rova (Cinchonoideae) on the one hand, and the Condamineeae-Calycophylleae-Hippotideae-Simireae-complex (Ixoroideae: see also further) and several other genera that are excluded, on the other hand. 


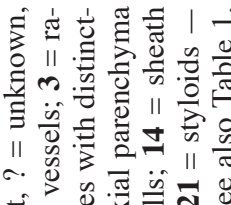

ثี> 离

111 îं

華।

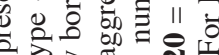

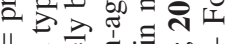

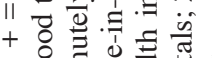

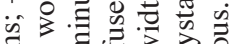

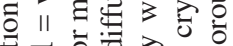

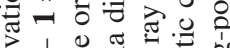

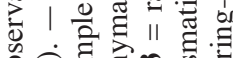

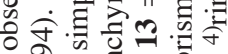

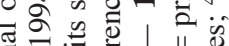
해를

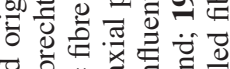
嗼

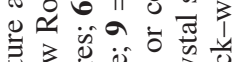

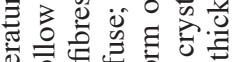
可 $\overline{0} 0$. छ

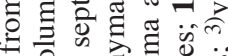

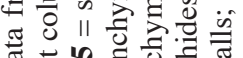
壱 的氜 专 ธี

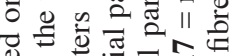

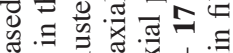

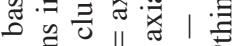

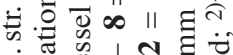

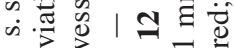

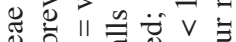

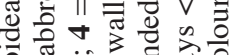

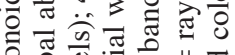

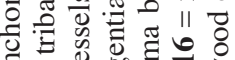

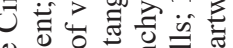
巳

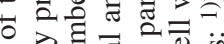

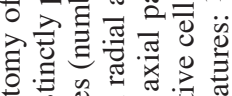

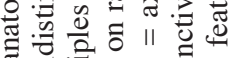

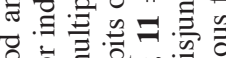

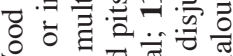

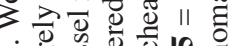

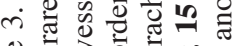
光

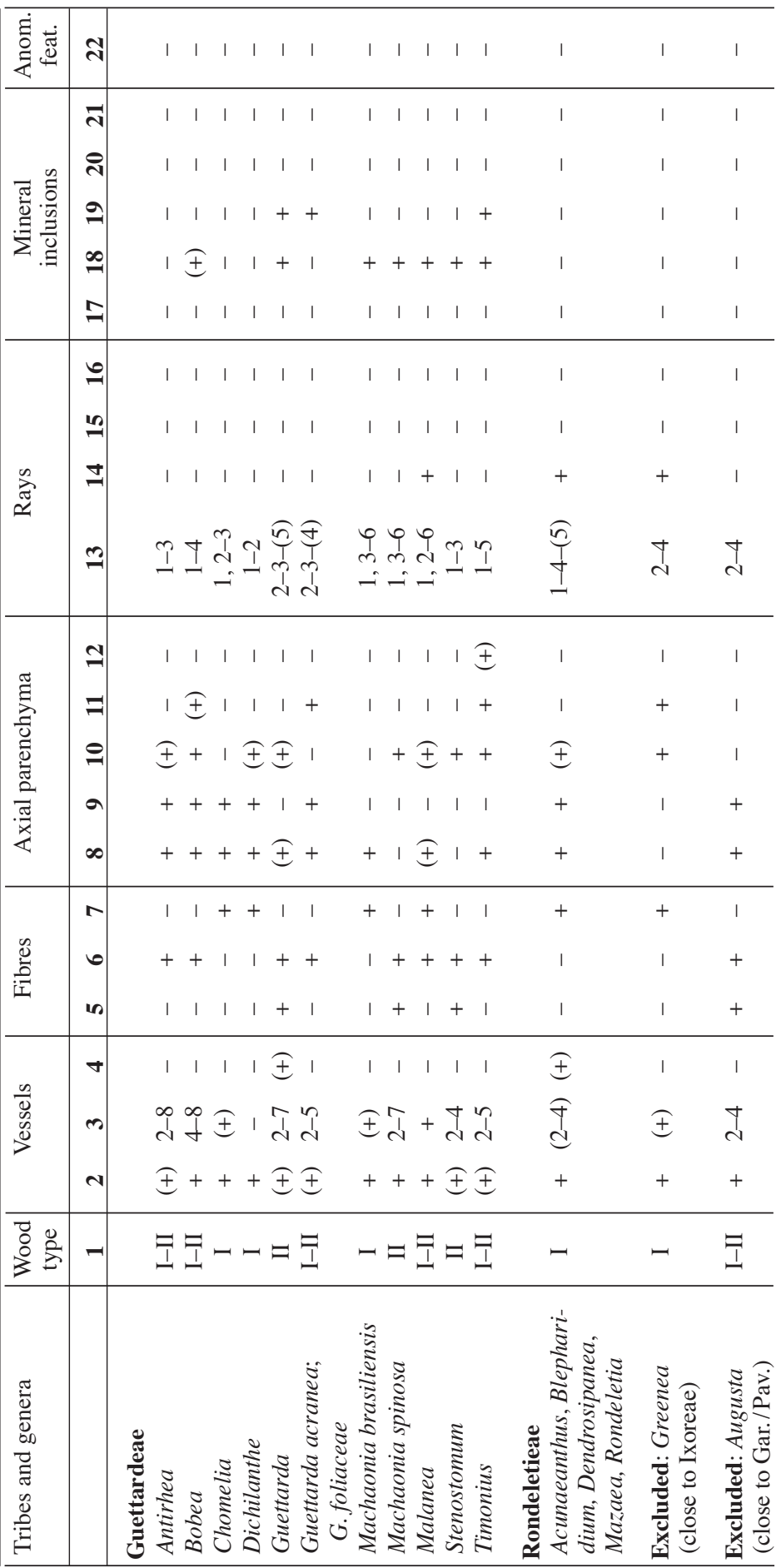




\begin{tabular}{|c|c|c|c|c|c|c|c|c|c|c|c|c|}
\hline 1 & 1 & $=0$ & $\widehat{\imath}$ & 1 & & $\hat{n} \bar{m}$ & & 1 & 11 & 1 & 1 & $\prec$ \\
\hline 1 & 1 & & 1 & 1 & & $1+$ & & 1 & +1 & 1 & 1 & \\
\hline 1 & 1 & + & 1 & 1 & I & 11 & & 1 & 11 & 1 & 1 & 1 \\
\hline 1 & 1 & 1 & 1 & + & I & 11 & & 1 & 1 ક & 1 & 1 & 1 \\
\hline 1 & + & 1 & 1 & 1 & I & 1 1 & & 1 & 11 & 1 & Ð & 1 \\
\hline 1 & 1 & 1 & + & + & 1 & 11 & & 1 & 11 & 1 & 1 & 1 \\
\hline 1 & 1 & 1 & 1 & 1 & & ++ & & 1 & 11 & 1 & 1 & 1 \\
\hline 1 & 1 & 1 & 1 & 1 & & 11 & & 1 & 11 & 1 & I & 1 \\
\hline+ & + & 13 & Ð & 1 & & 11 & & 1 & ક 1 & 1 & ક & 1 \\
\hline $\begin{array}{l}n \\
i \\
\\
-\end{array}$ & 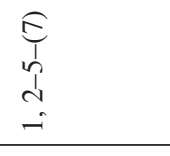 & $\begin{array}{l}n \\
1 \\
n \\
-1\end{array}$ & & $\begin{array}{l}\mathfrak{I} \\
I \\
I\end{array}$ & & $\begin{array}{ll}0 & 0 \\
1 & 1 \\
1 & 1\end{array}$ & & 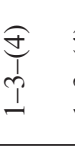 & 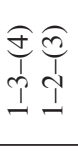 & 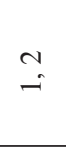 & 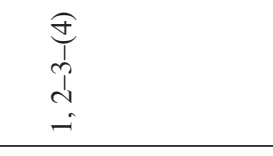 & - \\
\hline 1 & 1 & 1 & 1 & 1 & & $\underline{ \pm}+$ & & 1 & 11 & 1 & 1 & 1 \\
\hline I & 1 & 1 & 1 & 1 & & 1 I & & 1 & 11 & 1 & 1 & 1 \\
\hline 1 & Ð & ક & 1 & Ð & & I 1 & & 1 & $1+$ & ક & + & 1 \\
\hline+ & 1 & 1 & 1 & 1 & & 11 & & + & ++ & 1 & + & + \\
\hline+ & 1 & 1 & 1 & 1 & & 11 & & + & +1 & ક & + & + \\
\hline+ & I & 1 & 1 & 1 & & ++ & & + & ++ & 1 & + & + \\
\hline 1 & + & + & + & + & & 1 1 & & 1 & 11 & + & 1 & 1 \\
\hline 1 & + & + & + & + & & 1 1 & & 1 & 11 & + & 1 & 1 \\
\hline 1 & Ð & 1 & 1 & 1 & & 土ક & & 1 & $1+$ & 1 & ‡ & $\sigma$. \\
\hline $\begin{array}{l}\underset{f}{d} \\
d\end{array}$ & $\underset{\sim}{ \pm}$ & $\stackrel{n}{n}$. & + & $\stackrel{+}{\wedge}$ & & 11 & & $\begin{array}{c}\widehat{p} \\
d \\
d\end{array}$ & $\begin{array}{l}+\infty \\
\sim \\
\sim\end{array}$ & $\underset{\sim}{+}$ & $\underset{d}{\stackrel{f}{d}}$ & a. \\
\hline+ & + & $\mp 3$ & & + & & ++ & & + & 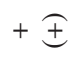 & Ð & + & $\sigma$. \\
\hline- & $=$ & $=$ & $\Xi$ & $=$ & & - & & - & $\neg-$ & $=$ & - & - \\
\hline 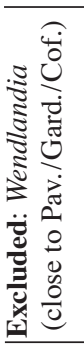 & 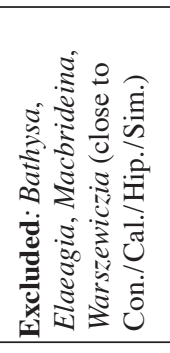 & : & & 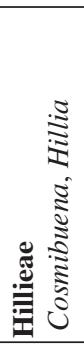 & 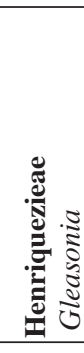 & 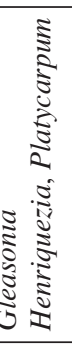 & 范 & 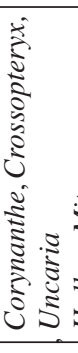 & 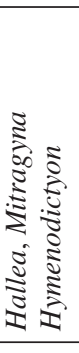 & 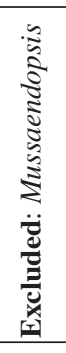 & 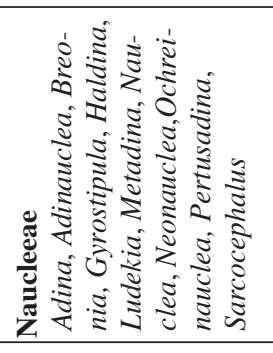 & 苞 \\
\hline
\end{tabular}




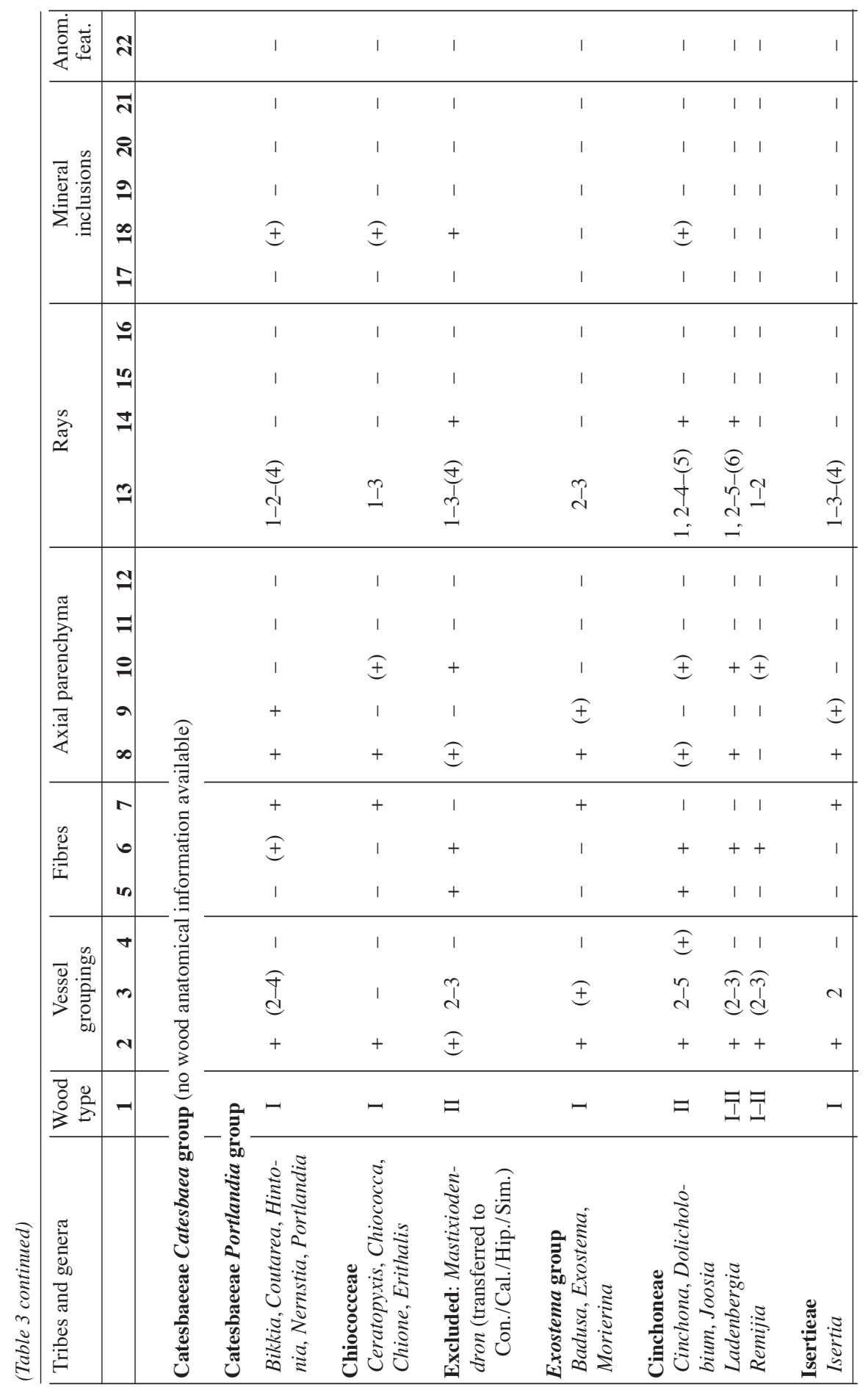



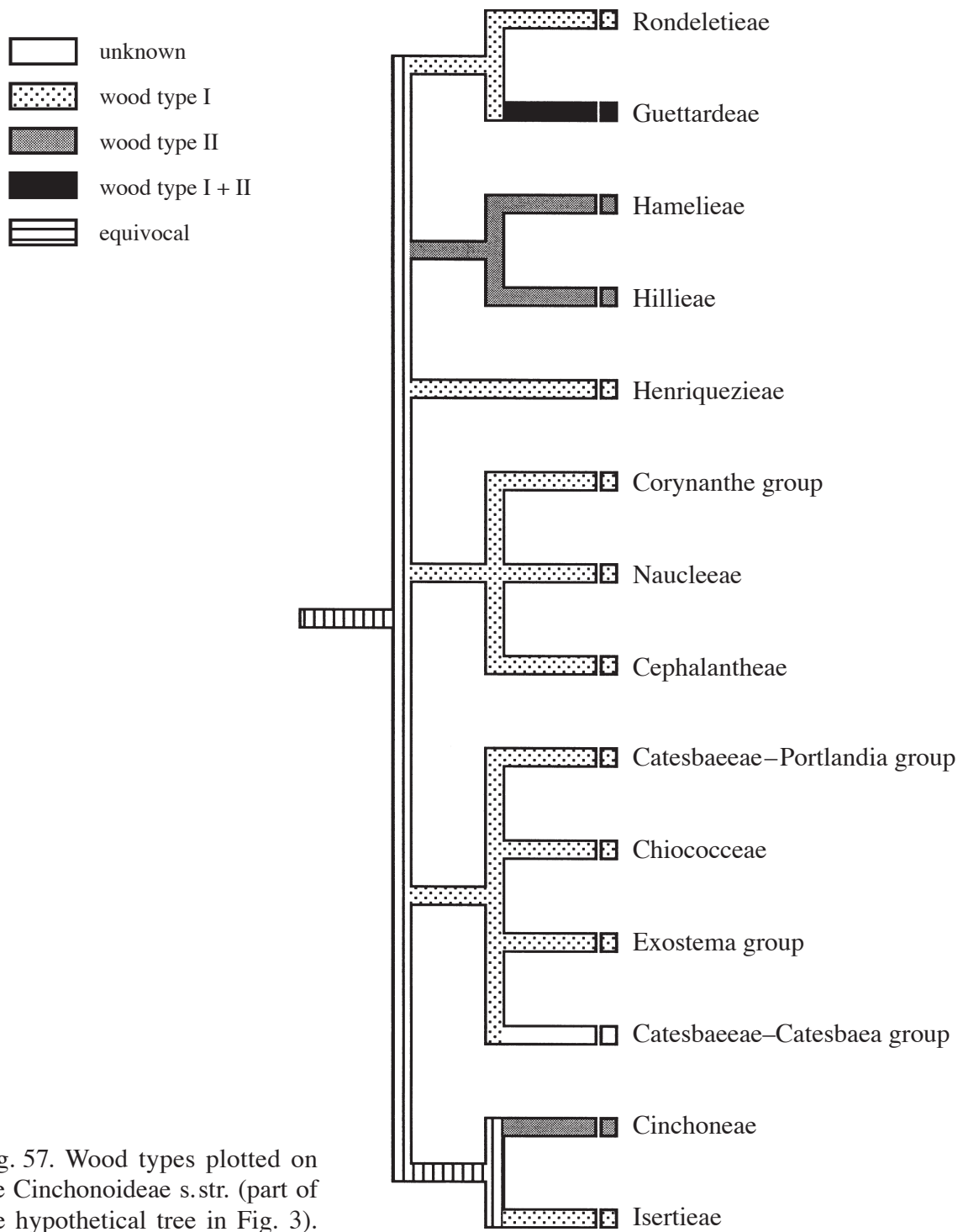

Fig. 57. Wood types plotted on the Cinchonoideae s. str. (part of the hypothetical tree in Fig. 3).

The placement of Greenea within or near the Ixoreae as found by Rova (1999) can be supported by the presence of parenchyma bands ( 2 to 4 cells wide), but the presence of axial parenchyma bands could also have been developed by its lianescent habit. As far as we know, styloids do not occur in Greenea and this crystal type is characteristic of most Ixoreae (Jansen et al. 1999). Moreover, the suggested transfer of Lindenia (synonymised with Augusta; Kirkbride 1997) to the Gardenieae or Pavetteae (Rova 1999) cannot be supported by the presence of septate libriform fibres (characteristic of type II), but the parenchyma type and vessel arrangement suggests wood type I, which is characteristic of the core Ixoroideae. 


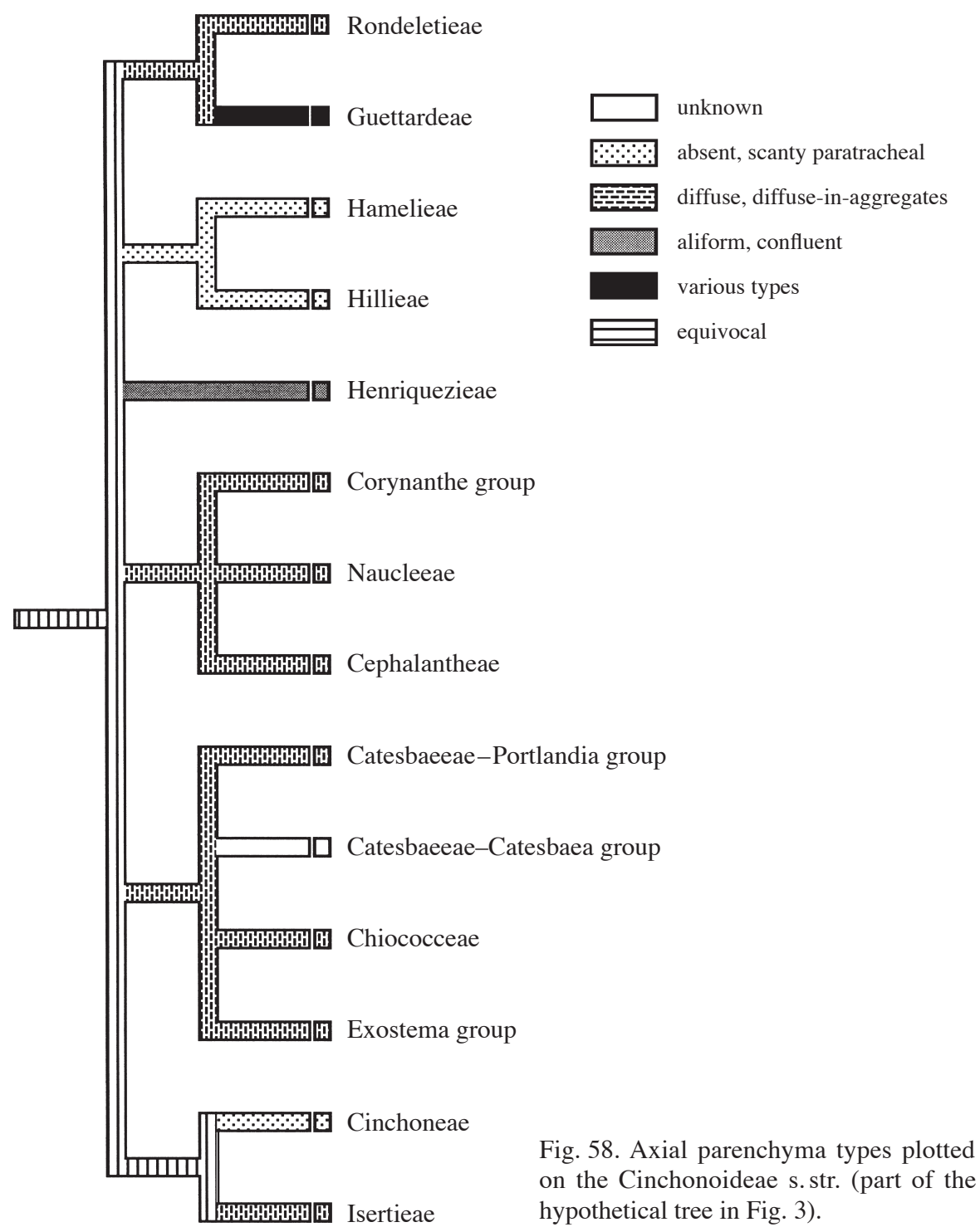

Wood anatomy of the Guettardeae has been studied in detail by Ter Welle et al. (1983), who concluded that the tribe is heterogeneous. In fact, the large wood anatomical variation in this tribe is striking compared to the general homogeneity of other, even much larger tribes such as the Gardenieae and Psychotrieae. Wood type I is most common in the Guettardeae, but type II is observed in Stenostomum, most species of Guettarda, and Machaonia spinosa. Crystal sand is present in ray cells of several genera, but the occurrence of (small) prismatic crystals, sometimes in combination with crystal sand, in Guettarda and Timonius is remarkable and not observed in other Cinchonoideae (Fig. 57-59). 


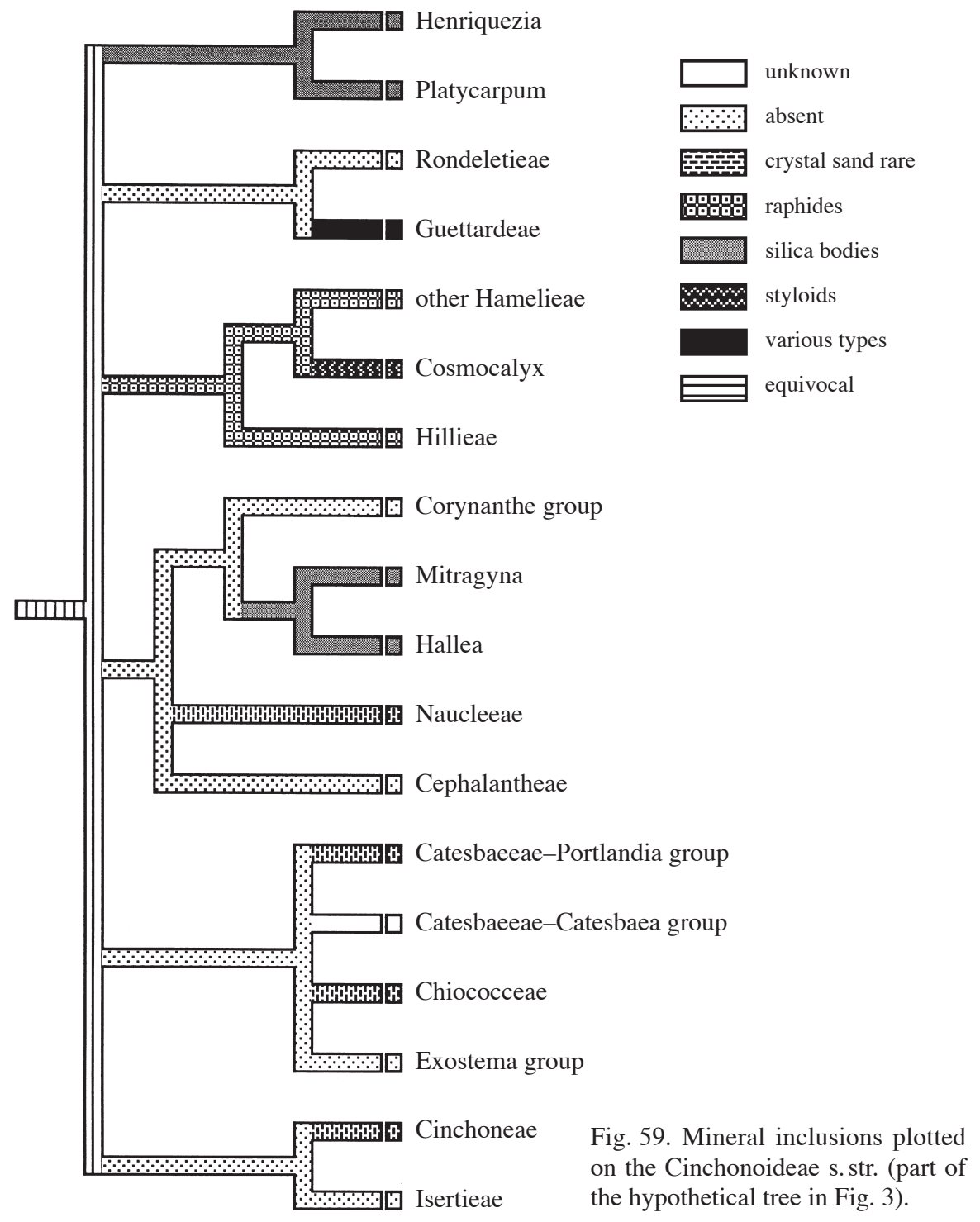

According to the molecular analysis of Rova (1999), the Hawaiian genus Bobea takes a basalmost position in a clade including several Guettardeae. Wood type I of Bobea shows indistinct to distinctly bordered pits, confined to radial fibre walls, and axial parenchyma which is diffuse to diffuse-in-aggregates. Darwin (1979) proposed for Bobea a position close to Timonius, Antirhea and Guettarda. While there is no wood anatomical difference between Antirhea, a location of Bobea near Timonius and most species of Guettarda appears strange from a wood anatomical point of view. Further evidence is needed to understand the isolated position of Bobea since this can be caused by the narrow sampling of taxa in the molecular analysis of Rova (1999). 
Considerable differences in wood structure occur between Machaonia brasiliensis and M. spinosa. This may indicate that the species studied by Ter Welle et al. (1983) need verification regarding their identification, or that the genus is not monophyletic. Moreover, the results of Rova (1999) suggest that the tribe Guettardeae as described by Robbrecht $(1988,1994)$ is most likely polyphyletic, with two major clades: one consisting of Machaonia (and Allenanthus), and one including Guettarda, Antirhea, Chomelia, Malanea and Timonius. It is clear that the delimitation of the Guettardeae needs further research if we want to understand the wood anatomical heterogeneity of this tribe.

In addition to a similar wood type, the close relationship between Hillieae and Hamelieae is supported by the presence of raphides, which are also found in the secondary xylem. Initially, the tribe Hamelieae has been included in the Rubioideae because of the presence of raphides (Verdcourt 1958; Bremekamp 1966; Robbrecht 1994), but it was excluded from the Rubioideae on the basis of $r b c \mathrm{~L}$ data (e.g. Bremer et al. 1995). Hamelieae also lack the large deletion containing one of the atp $\mathrm{B}$ promotors which is characteristic of the Rubioideae (Manen \& Natali 1996).

Based on morphological characters, Delprete (1998) strongly advocated the inclusion of the genus Cosmocalyx in the Hamelieae. The heartwood of this genus turns intensely pinkish red to almost purplish when freshly exposed to air (Richter \& Schmitt 1987). This rare phenomenon is shared with species of the genus Simira (Simireae, Ixoroideae s.1.), Deppea and Hamelia (Hamelieae), and Syringantha (Lorence \& Dwyer 1988; Delprete \& Nee 1997). McDowell (1996) recently included the monospecific Syringantha in the Hamelieae, which had previously been transferred from the Cinchoneae to the Condamineeae by Andersson and Persson (1991). Moreover, Richter and Schmitt (1987) reported that remarkably large styloids occur in idioblasts of Cosmocalyx (Fig. 59). Styloids occur only seldomly in rubiaceous wood, and are only known, as far as we know, in the wood of Ixoreae and a single species of Morinda (Morindeae). The presence of raphides in other tissues of Cosmocalyx is in accordance with the Hamelieae and Hillieae (Delprete 1998). As observed in leaves of some Rubiaceae (e.g. several genera of Psychotrieae), styloids appear to show morphological similarities to raphides (Cody \& Horner 1983), which is also suggested by the occurrence of styloids in multiple groups stacked tightly in large pocket-like idioblasts of Cosmocalyx. The genus Simira (a tribe of its own or Rondeletieae sensu latissimo) has a complicated taxonomic history (Delprete \& Nee 1997). In view of the genus' reddish tinged wood, Simira should definitely be reconsidered in the context of the Hamelieae.

The tribe Henriquezieae is wood anatomically rather isolated from the remaining Rubiaceae (Koek-Noorman 1980). Indeed, vessel elements of large diameter, the aliform to confluent axial parenchyma, and the uniseriate, relatively low rays are unusual in Rubiaceae and suggest a derived status (Fig. 57-59). Koek-Noorman (1980) suggested that Platycarpum and Henriquezia are closely related by their aliform to confluent xylem parenchyma, while the axial parenchyma in Gleasonia is only scanty paratracheal. Rogers (1981), however, also encountered aliform to confluent parenchyma in Gleasonia, suggesting that this genus cannot be separated from Henriquezia and Platycarpum. Outside the Henriquezieae, more or less aliform to confluent pa- 
renchyma is only occasionally reported in Timonius and unilaterally aliform parenchyma is rarely observed in Dichilanthe (Ter Welle et al. 1983). The presence of silica bodies in Platycarpum and Henriquezia appears to support the close relationship between both genera, although this feature is only recorded in few wood samples (Fig. 59). According to Rova (1999), Gleasonia should belong to the subfamily Ixoroideae s. l. on the basis of $\operatorname{trn} \mathrm{L}-\mathrm{F}$ sequence data. He found a strongly supported group comprising the Henriquezieae with a tentative new tribe including Posoqueria and Molopanthera. Wood anatomical data of Molopanthera are not available, but we have data on the wood structure of Posoqueria. Robbrecht and Puff (1986) accepted the classical position of Posoqueria in the Gardenieae, despite aberrant features; the results of Andreasen and Bremer (2000), however, demonstrated that Posoqueria should be a member of the basal Ixoroideae s.1. Koek-Noorman (1972) pointed out that the wood structure of Posoqueria deviates in some important features (especially nonseptate libriform fibres) from the other Gardenieae. The genus also differs in its radial vessel multiples, small (navicular or cubic) prismatic crystals and the more paratracheal axial parenchyma distribution. Although the wood of Posoqueria differs in several points from that of the Henriquezieae, we observed very small mineral inclusions in the ray cells of Posoqueria latifolia, which resemble the silica bodies as present in Platycarpum and Henriquezia. However, the combined occurrence of small prismatic crystals and silica bodies in the same specimen puts doubt on the siliceous nature of these inclusions, because silica bodies and crystals generally are mutually exclusive (Scurfield et al. 1974). Hence, verification by EDX-analysis is required to identify the precise composition.

The Corynanthe group, Naucleeae and Cephalantheae all show wood type I, which supports the coherence of these groups. Razafimandimbison and Bremer (2000) suggested to include these taxa in the Naucleeae s.l., since the delimitation of Naucleeae sensu Ridsdale and the Coptosapelteae sensu Andersson is no longer tenable. There is one exception regarding the wood type: Mussaendopsis clearly shows all characters of wood type II. Since Mussaendopsis was only tentatively included in the Coptosapelteae (Puff \& Igersheim 1994a; Robbrecht 1994) and found to fall outside the Naucleeae s.l. (Razafimandimbison \& Bremer 2000), wood anatomy supports the exclusion of this genus. Moreover, the molecular and morphological data demonstrated that Hallea and Mitragyna form a well-supported clade with a very high bootstrap value, which is supported by the occurrence of silica bodies in ray cells. Thus, silica bodies are possibly a synapomorphy for both genera, while crystal sand is present in several genera of the Naucleeae sensu Ridsdale (Adina, Breonia, Nauclea) (Fouarge et al. 1953; Brazier \& Franklin 1961; Scurfield et al. 1974; Normand \& Paquis 1976; Ter Welle 1976). Our observation of small silica inclusions in Crossopteryx is new for this genus but needs verification.

Chiococceae, Catesbaeeae (Catesbaea group and Portlandia group) and the informal Exostema group form a complex and there is increasing evidence to merge these taxa into a single tribe Catesbaeeae s.l. (Rova 1999). We had no material available for the Catesbaea group, and literature does not report on its wood. In the other members of the complex, wood type I is universally present, except for Mastixiodendron. This genus should be excluded from the Chiococceae-Catesbaeeae complex (Huysmans 


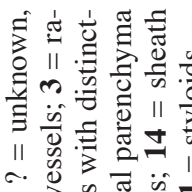

$\vec{\exists}>\mathscr{d}$ 跑 듕을 형

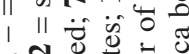

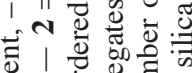

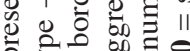
2 2 㲾 II $\overrightarrow{0} . \unlhd$

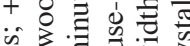

ธ ॥ 券 ।

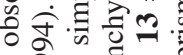
플을

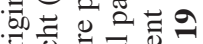

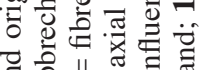
चี 숭 के

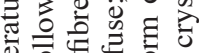

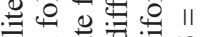

घี

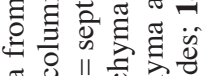

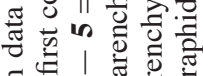
。ำ

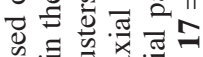

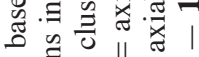
- .00 的.气

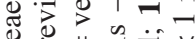
8 i $=\ddot{0} v$

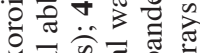

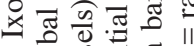
प्丶 む)

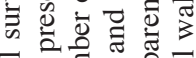

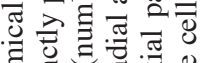

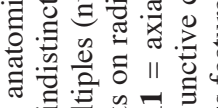

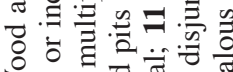

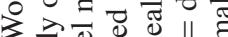

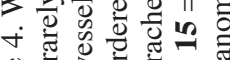

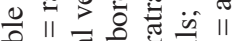

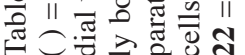

\begin{tabular}{|c|c|c|c|c|c|c|c|c|}
\hline 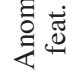 & ปี & 1 & 1 & 1 & 1 & 1 & & 1 \\
\hline \multirow{5}{*}{ 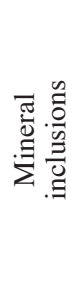 } & त & 1 & 1 & 1 & 1 & 1 & & I \\
\hline & సิ & 1 & 1 & 1 & 1 & 1 & & 1 \\
\hline & 2 & 1 & 1 & 1 & 1 & 1 & & 1 \\
\hline & $\infty$ & + & + & + & + & + & & 1 \\
\hline & 二 & 1 & 1 & 1 & 1 & 1 & & 1 \\
\hline \multirow{4}{*}{$\sum_{\tilde{\Theta}}^{\infty}$} & 의 & 1 & I & 1 & 1 & I & & 1 \\
\hline & 12 & 1 & 1 & 1 & 1 & 1 & & 1 \\
\hline & $\Xi$ & + & Ð & + & + & ક & & -1 \\
\hline & 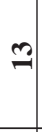 & $\stackrel{f}{f}$ & 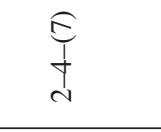 & $\begin{array}{l}\widehat{a} \\
I \\
I\end{array}$ & $\begin{array}{l}\infty \\
1 \\
i \\
\sim \\
\\
-\end{array}$ & $\begin{array}{l}0 \\
1 \\
1 \\
1\end{array}$ & & $\sigma$. \\
\hline \multirow{5}{*}{ 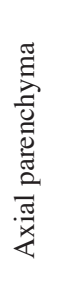 } & $\mathcal{\imath}$ & 1 & 1 & 1 & 1 & 1 & & 1 \\
\hline & $\Rightarrow$ & 1 & 1 & 1 & 1 & 1 & & 1 \\
\hline & $=$ & ક & + & Ð & I & 1 & & Ð \\
\hline & a) & 1 & 1 & 1 & 1 & + & & I \\
\hline & $\infty$ & 1 & Ð & 1 & 1 & 1 & & 1 \\
\hline \multirow{3}{*}{ 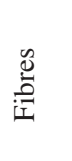 } & $N$ & 1 & 1 & 1 & 1 & 1 & & 1 \\
\hline & b) & + & + & + & + & + & + & + \\
\hline & in & + & + & + & + & + & & + \\
\hline \multirow{3}{*}{$\begin{array}{l}\frac{n}{0} \\
0 \\
0 \\
j\end{array}$} & $\nabla$ & 1 & ક & I & I & 1 & & 1 \\
\hline & $m$ & $\stackrel{a}{a}$ & $\stackrel{a}{\lambda}$ & $\stackrel{n}{\sim}$ & $\underset{\sim}{ \pm}$ & ${ }_{m}^{+}$ & & -1 \\
\hline & $N$ & I & I & I & I & + & + & + \\
\hline 总 & - & $=$ & $\exists$ & $=$ & $=$ & $=$ & $=$ & 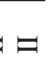 \\
\hline 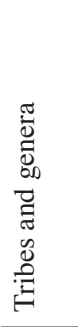 & & 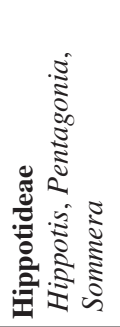 & 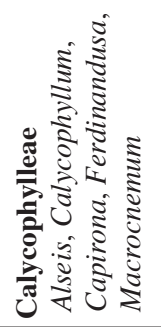 & 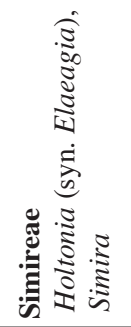 & 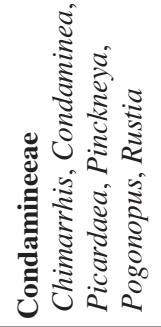 & 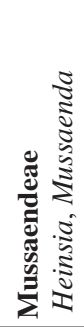 & 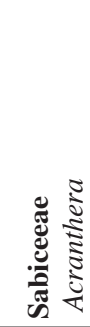 & 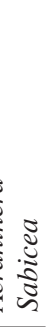 \\
\hline
\end{tabular}




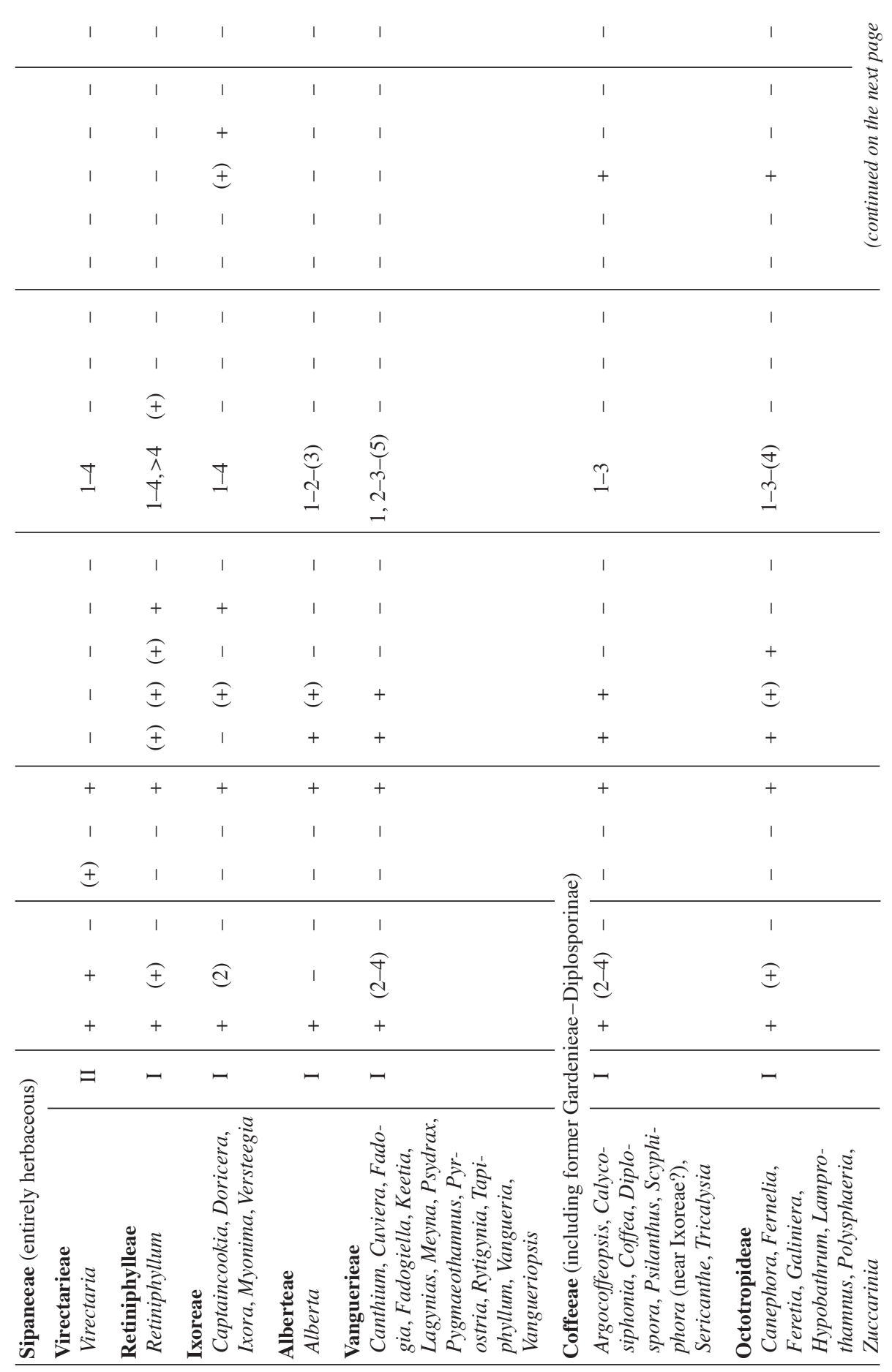




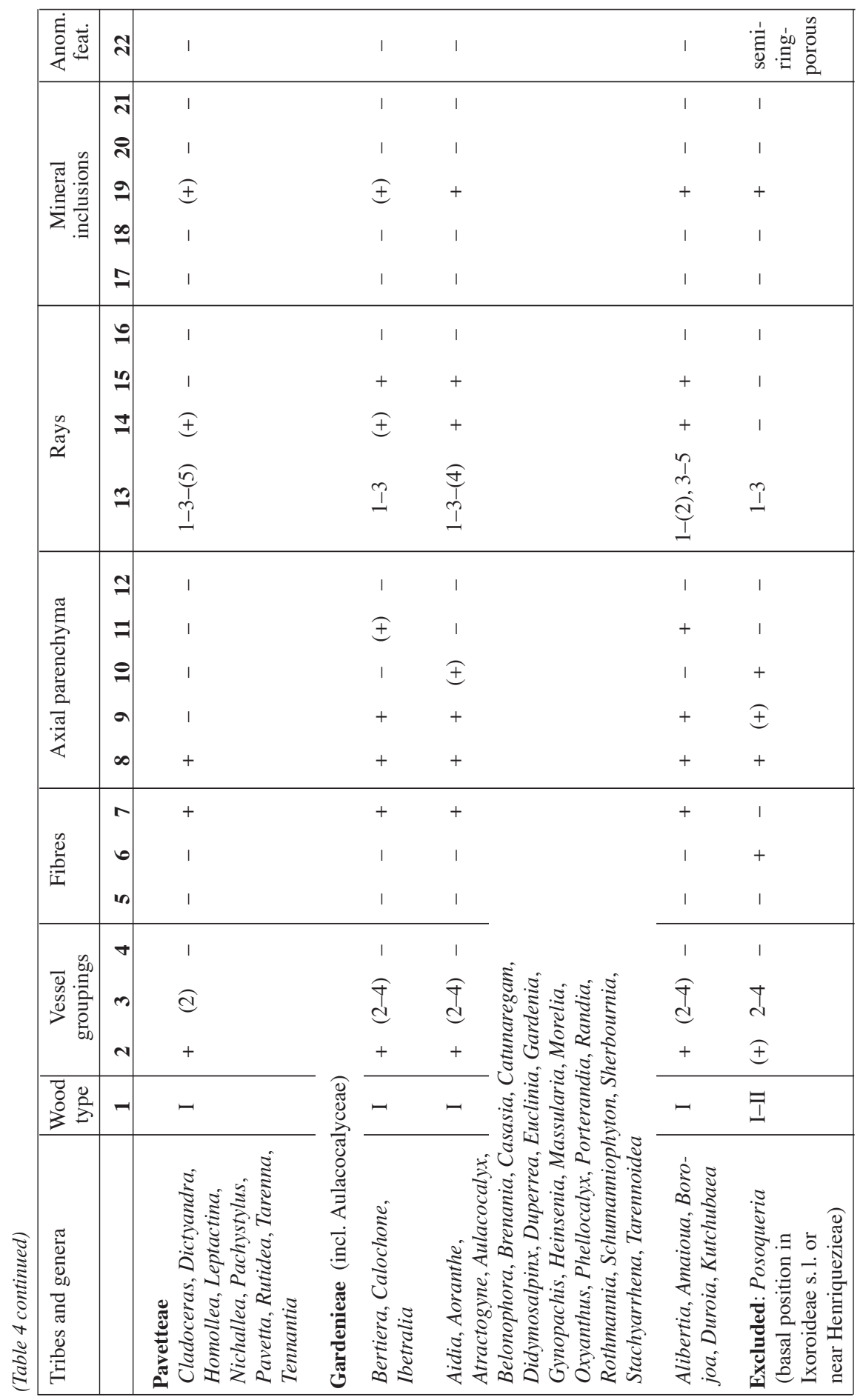


et al. 1999; see also below). Although Chione (formerly in the complex) falls in a basal position in a clade together with representatives of the Hillieae and Hamelieae (Rova 1999), the present study shows that the wood type of Chione differs from that of Hillieae and Hamelieae.

The tribe Cinchoneae is relatively homogeneous in its secondary xylem. Three genera within Cinchoneae show wood type II, but the wood structure encountered in Ladenbergia better fits with type I. Remijia also shows fibre tracheids with distinctly bordered pits, but axial parenchyma is only rarely paratracheal to absent, which is more characteristic of type II. A careful examination of macerated tissue did not reveal any septate fibres in Ladenbergia and Remijia. Furthermore, crystal sand is common in ray cells of the Cinchoneae and scalariform vessel-ray pitting is reported in Joosia.

The former tribe Isertieae collapsed and was reduced to two genera: Isertia (including Yutajea) and Kerianthera (Bremer \& Thulin 1998). The secondary xylem of Isertia shows the presence of wood type I. This is in contrast to wood type II occurring in genera that were previously included in Isertieae: Mussaenda and Heinsia (Mussaendeae), and Mycetia (Argostemmateae). Gonzalagunia which shows wood type I is suggested to be closely related to Guettardeae, in which wood type I and II are both observed. The abundant presence of small prismatic (especially navicular) crystals in parenchyma cells of Gouldia, which is synonymised to Hedyotis (Wagner et al. 1989), supports the exclusion from Isertieae. This crystal type is mainly recorded in the subfamily Rubioideae.

\section{SubFAMILY IXOROIDEAE s.1. (Fig. 60-62; Table 4)}

One of the most significant conclusions from the present survey appertains to the distribution of the wood types in the Ixoroideae, namely exclusively type $I$ in the core Ixoroideae, versus exclusively type II in the two other clades of the Ixoroideae (Fig. 60).

A close affinity between the Hippotideae, Calycophylleae, Simireae and Condamineeae is generally supported by cladistic analyses based on molecular data, but internal resolution in this clade is poor (Bremer et al. 1999; Rova 1999). All wood samples of this group show wood type II and crystal sand is very common in ray cells. Genera that recently have been transferred to this clade include: Bothriospora, Elaeagia, Macrocnemum, Mastixiodendron and Warszewiczia (Andersson 1995; Rova 1999). The genus Mastixiodendron is probably the only genus within Rubiaceae that shows free petals, a character also present in the enigmatic genus Dialypetalanthus (Piesschaert et al. 1997). Plastid $r b c$ L sequence data has demonstrated that Dialypetalanthus is a member of Rubiaceae (Fay et al. 2000), in a clade with neotropical genera of the Calycophylleae, Hippotideae and Condamineeae. However, this clade received very little bootstrap support. The wood structure of Mastixiodendron closely resembles that of Dialypetalanthus, but it remains necessary to turn to other fields of evidence to elucidate the exact position of Dialypetalanthus and Mastixiodendron and corroborate a possible relationship between the two genera.

The Mussaendeae were re-established as a separate tribe of Ixoroideae s.1. by Bremer and Thulin (1998). Genera included in Mussaendeae for which we have wood data 


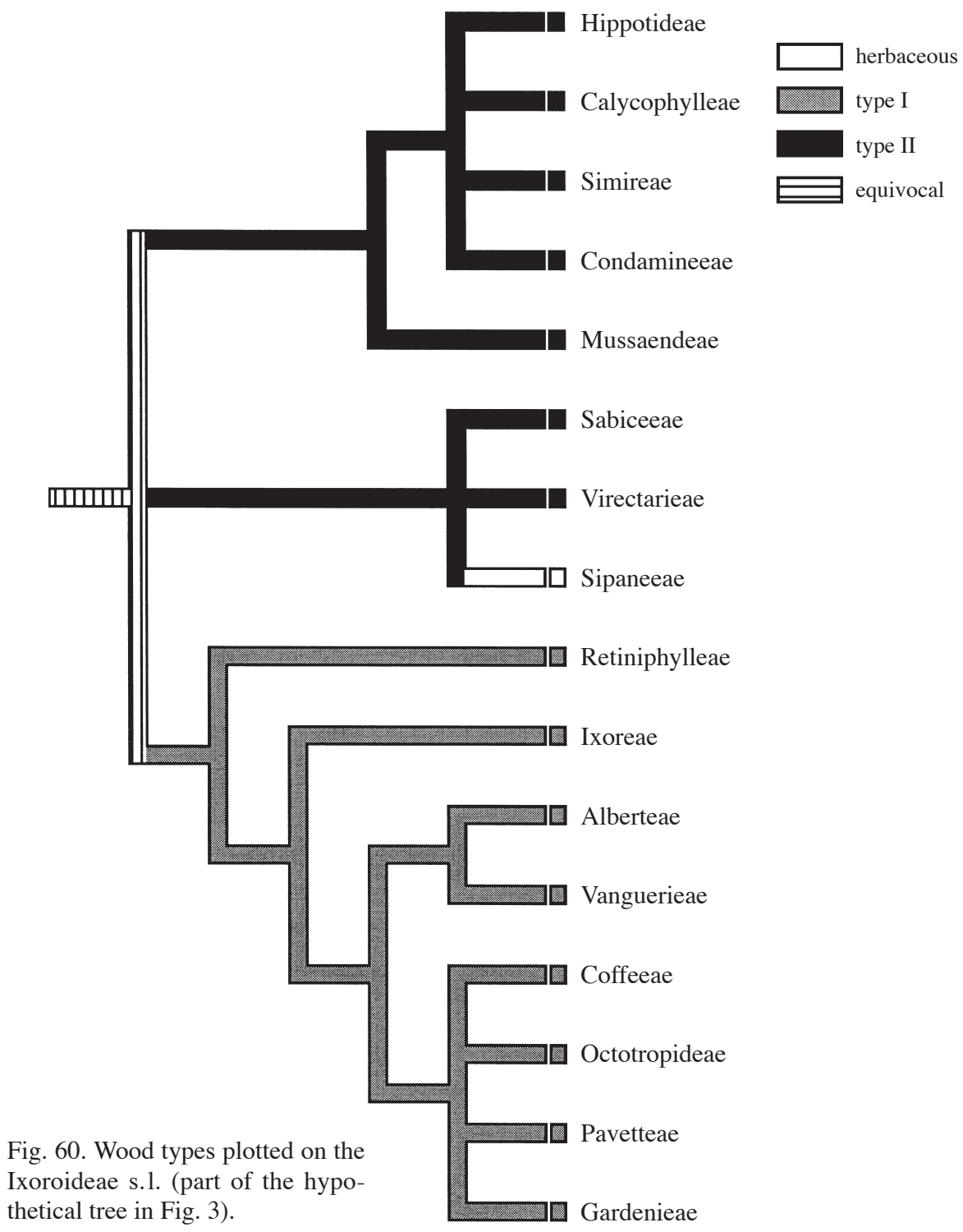

are Heinsia and Mussaenda. Both genera have thin-walled fibres with septa and minutely bordered pits that are restricted to radial walls (type II).

We have little or no wood anatomical information of the more herbaceous tribes Sabiceeae and Virectarieae. The related tribe Sipaneeae is entirely herbaceous. Wood of the genus Virectaria shows absence of axial parenchyma, solitary vessels or rarely arranged in short radial multiples, and fibres with simple or reduced pit borders on radial walls (Dessein et al. 2001b). Septate fibres were not recorded in all representatives studied, but they are clearly present in a specimen of Virectaria major. Accord- 


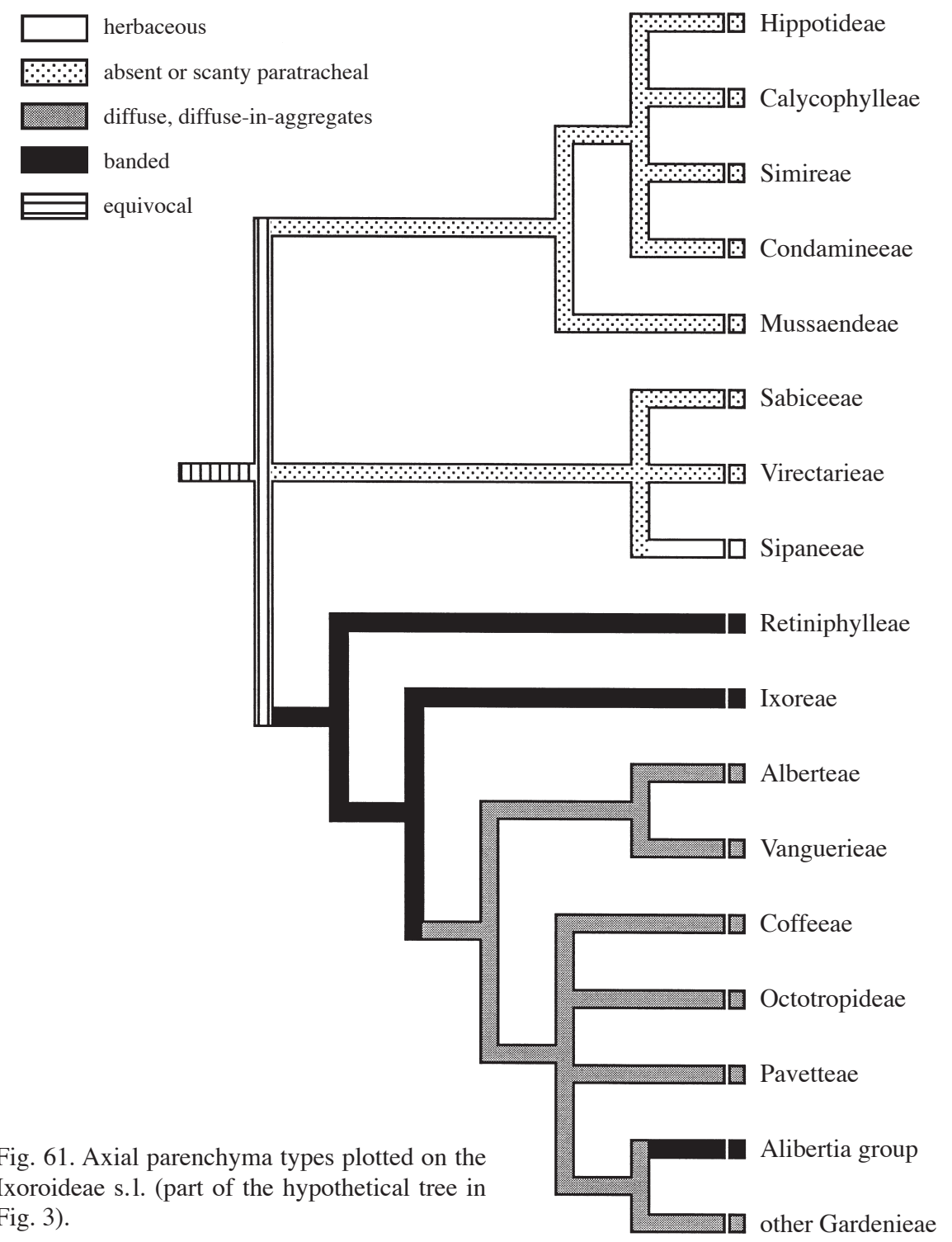

ingly, these features are more typical of wood type II than of type I. The very small wood samples of Sabicea examined by us showed septate libriform fibres, but more material should be examined of the remaining genera (e.g. Pseudosabicea, Tamridea) before we can conclude that wood type II is consistently present in Sabiceeae. Bremer and Thulin (1998) noticed that Acranthera may perhaps not belong to the Sabiceeae. Wood type II in Acranthera, however, can be interpreted as additional support for a position within the Sabiceeae. 


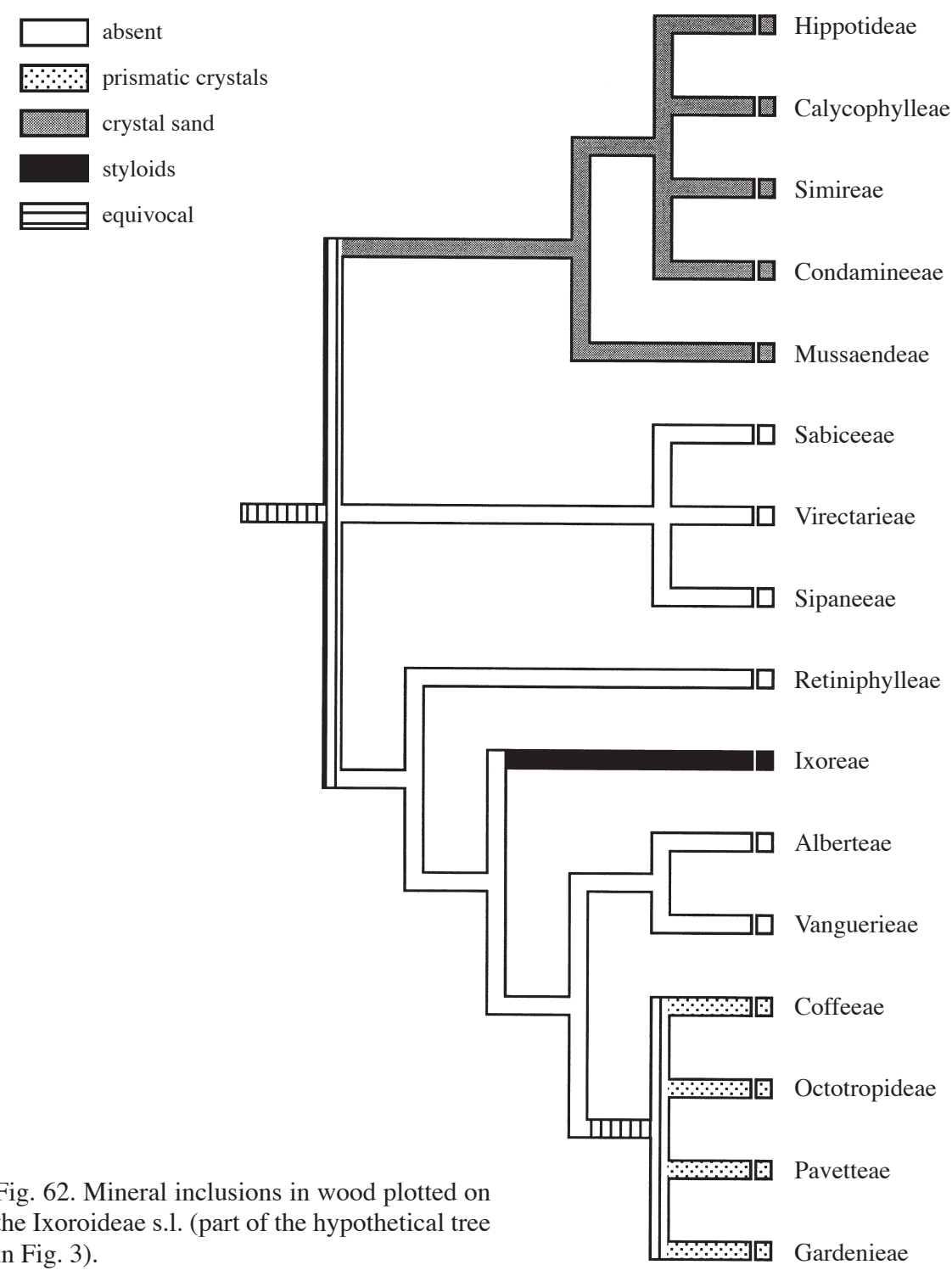

The core Ixoroideae Retiniphylleae, Ixoreae, Alberteae, Vanguerieae, Coffeeae, Octotropideae, Pavetteae, and Gardenieae are all characterised by wood type I. Although disjunctive elements are found in all subfamilies of Rubiaceae, this feature appears to be most common in this clade. The Retiniphylleae appear to take a basal position as sister group of the core Ixoroideae. The presence of axial parenchyma bands is found in two basal tribes of the core Ixoroideae, namely Retiniphylleae and Ixoreae (Fig. 61). As argued by Jansen et al. (1999), axial parenchyma bands in Ixoreae distinguish this group from Pavetteae. The exclusion of Ixora and allies from the Pavetteae s.l. 
and recognition of the tribe Ixoreae was also proposed by Andreasen and Bremer (2000) on the basis of $r b c \mathrm{~L}$ data. The occurrence of long and wide parenchyma bands in Retiniphyllum, the only genus of the Retiniphylleae, probably indicates the primitive position of this genus. Retiniphyllum is also recorded to show aliform to confluent parenchyma, which is very unusual in Rubiaceae. Parenchyma bands are absent in most members of the core Ixoroideae and diffuse to diffuse-in-aggregates is the main parenchyma type. However, the formation of narrow bands or lines up to three cells wide is also found in some closely related genera of the Gardenieae, namely the Alibertia group as proposed by Persson (1996, 2000; Alibertia, Amaioua, Borojoa, Duroia, and Kutchubaea; Fig. 61). Therefore, this feature probably supports the monophyly of the Alibertia group.

Prismatic crystals are very common in the wood of most core Ixoroideae having wood type I. In particular, they characterise the Gardenieae, Octotropideae, Coffeeae and to a lesser extent several Pavetteae (Fig. 62). The crystals are rhombic or octahedral and frequently solitary in ray cells. Styloids or elongate crystals distinguish the Ixoreae from the other core Ixoroideae. This crystal type was recorded in the wood of Captaincookia, Ixora and Versteegia.

Chambered prismatic crystals are frequently found in axial parenchyma cells of Tarenna, Nichallea, Homollea and Pavetta. As suggested by Jansen et al. (1999), this crystal type probably shows taxonomic significance at the generic or infrageneric level. Accordingly, the occurrence of prismatic crystals needs further verification, especially in the genus Tarenna s.l., the delimitation of which is the largest taxonomic problem in the Pavetteae.

Puff and Rohrhofer (1993) suggested a taxonomic position of the mangrove genus Scyphiphora in Gardenieae, especially within the subtribe Diplosporineae. The genus was excluded from the Gardenieae by Andreasen and Bremer (2000) since their cladistic analysis suggested a position near the Ixoreae although support for this relationship was not very strong. Wood anatomy of Scyphiphora shows no tendency to form small lines or bands of axial parenchyma, which is generally characteristic of Ixoreae.

Andreasen and Bremer (2000) demonstrated that Aulacocalyceae are deeply nested in and should be sunk into Gardenieae. There are no wood anatomical differences between these groups. Furthermore, the homogeneity in the wood structure of the core Ixoroideae does not allow to comment on the taxonomic position of a few genera recently discussed, viz. Aoranthe (Andreasen \& Bremer 2000) and Duperrea (De Block \& Robbrecht 1997).

\section{Subfamily RubioideAe (Fig. 63 \& 64; Table 5)}

The Rubioideae reveal a tendency to herbaceousness, although this habit presumably has one origin outside Rubioideae, namely in the clade consisting of Sipaneeae, Virectarieae and Sabiceeae (Ixoroideae s.1.; Fig. 63). The clades in which herbaceous taxa are most distinctly represented, are 1) Ophiorrhizeae, 2) Cruckshanksieae and Coccocypselum, 3) Mitchella and some Psychotrieae (e.g. Geophila, Hymenocoleus), and 4) the large Spermacoceae alliance (including Spermacoceae, Knoxieae, Hedyotideae, Theligoneae, Rubieae, Anthospermeae, Argostemmateae, and Paederieae). 


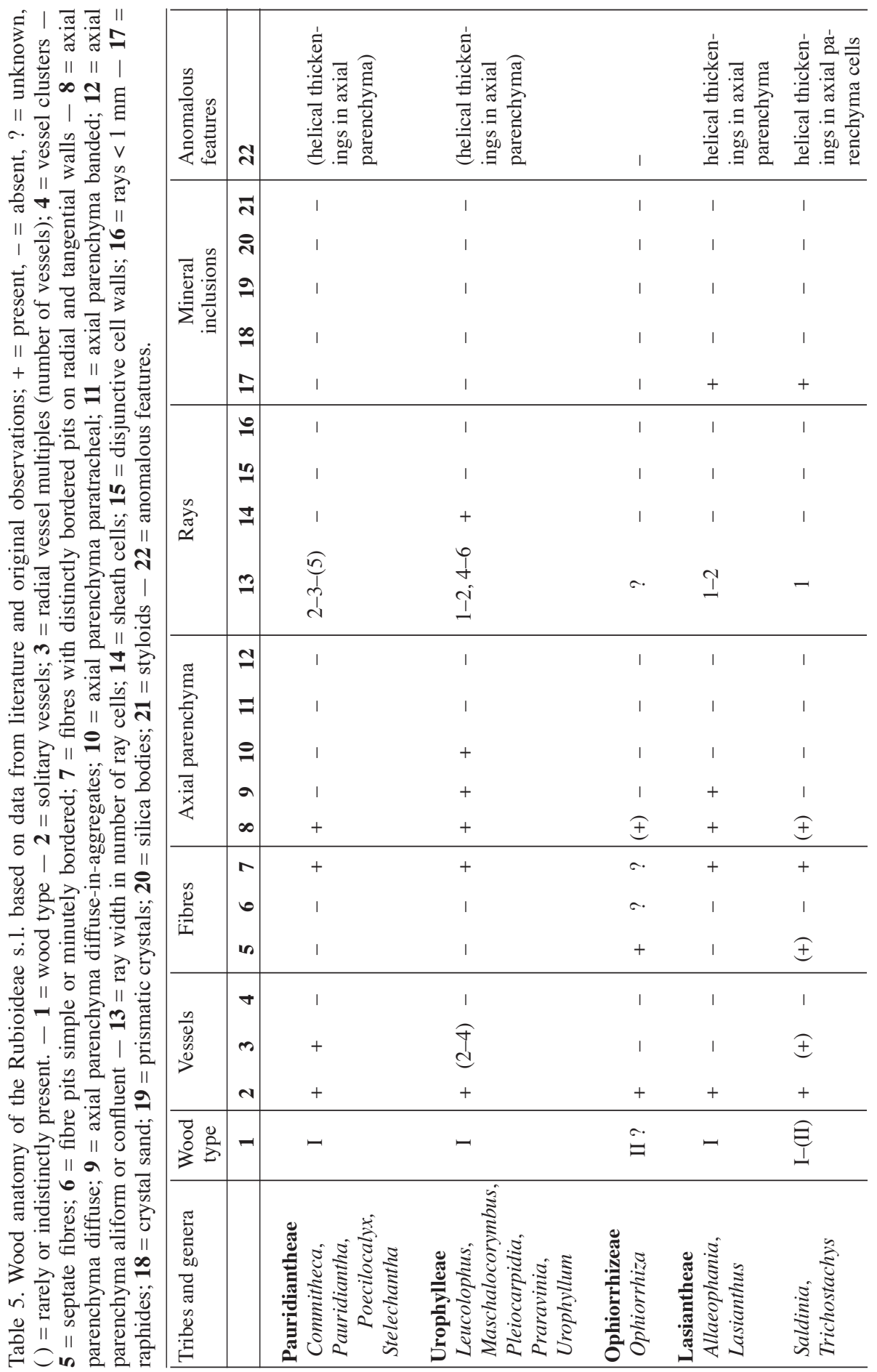




\begin{tabular}{|c|c|c|c|c|c|c|c|c|c|}
\hline 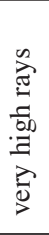 & 11 & 1 & 1 & 1 & 1 & 1 & 1 & 1 & 1 \\
\hline 1 & 11 & 1 & 1 & 1 & 1 & 1 & 1 & 1 & I \\
\hline 1 & 11 & 1 & 1 & 1 & 1 & 1 & 1 & ક & 1 \\
\hline 1 & 11 & 1 & 1 & 1 & 1 & 1 & 1 & 1 & I \\
\hline 1 & 11 & 1 & 1 & 1 & 1 & 1 & 1 & 1 & 1 \\
\hline+ & +1 & + & + & + & + & + & 1 & + & + \\
\hline 1 & 11 & 1 & 1 & 1 & 1 & 1 & 1 & 1 & I \\
\hline 1 & 11 & 1 & 1 & 1 & 1 & 1 & 1 & 1 & 1 \\
\hline+ & 11 & 1 & I & I & 1 & 1 & 1 & 1 & 1 \\
\hline$\stackrel{a}{\dot{t}}$ & 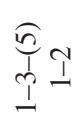 & $\stackrel{I}{I}$ & $\stackrel{i}{\sim}$ & $\begin{array}{l}0 \\
1 \\
1 \\
1 \\
0 \\
1\end{array}$ & $\underset{\substack{\sigma \\
\sim}}{\stackrel{\sigma}{\sigma}}$ & $I$ & $\underset{I}{\stackrel{d}{1}}$ & 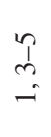 & 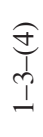 \\
\hline 1 & 11 & 1 & 1 & 1 & 1 & 1 & 1 & 1 & I \\
\hline 1 & 11 & + & 1 & + & + & 1 & 1 & + & 1 \\
\hline Ð & 11 & 1 & ક & 1 & + & ક & 1 & 1 & ક \\
\hline 1 & 11 & 1 & 1 & 1 & 1 & + & 1 & 1 & Ð \\
\hline 1 & 11 & 1 & 1 & 1 & + & + & 1 & + & 1 \\
\hline 1 & 11 & + & 1 & + & + & + & 1 & + & + \\
\hline+ & ++ & 1 & + & 1 & Æ & 1 & + & + & I \\
\hline+ & ++ & 1 & + & 1 & Æ & 1 & + & 1 & + \\
\hline 1 & 11 & 1 & Ð & 1 & Æ & 1 & 1 & 1 & 1 \\
\hline$\underset{\sim}{ \pm}$ & Ð + & $\widehat{d}$ & $\frac{O}{1}$ & $\underset{d}{\stackrel{f}{d}}$ & $\underset{d}{+}$ & 1 & a. & + & I \\
\hline+ & $+\subsetneq$ & + & Ð & + & + & + & a. & + & + \\
\hline$=$ & $\exists \boxminus$ & - & $\exists$ & - & $\underset{I}{\Theta}$ & $\neg$ & $\exists$ & $\underset{I}{\Theta}$ & - \\
\hline
\end{tabular}

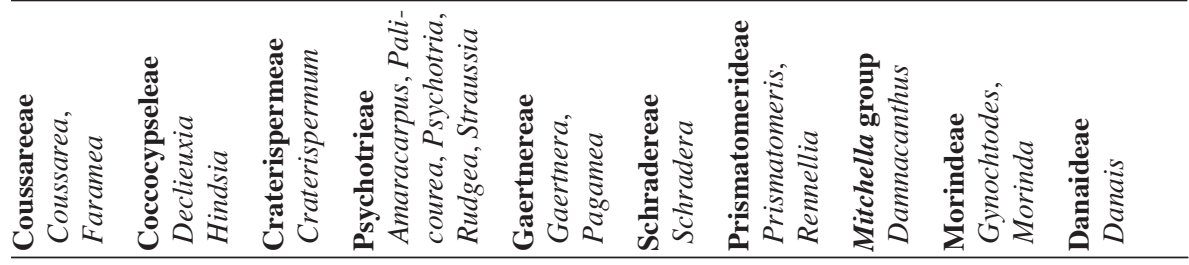




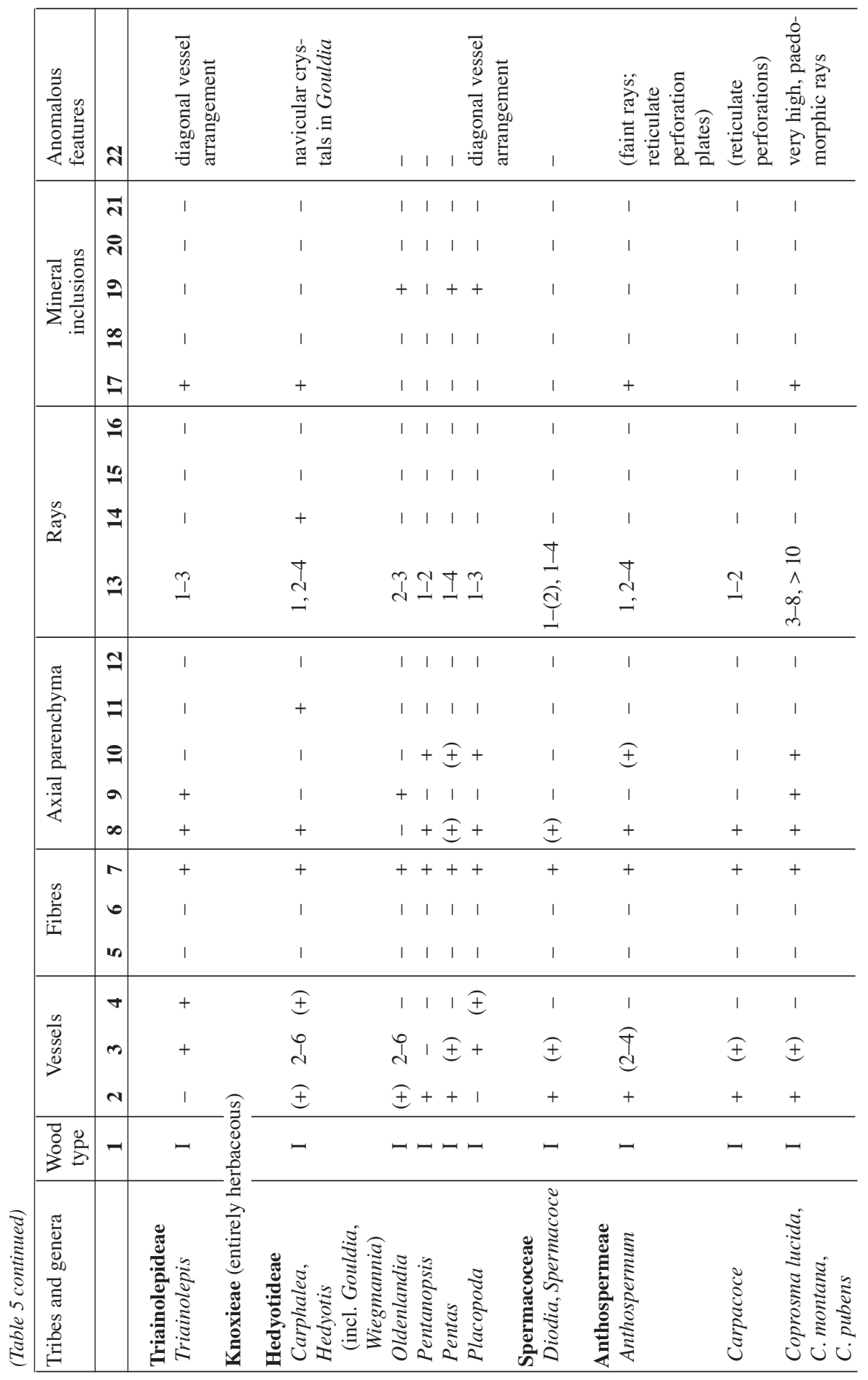




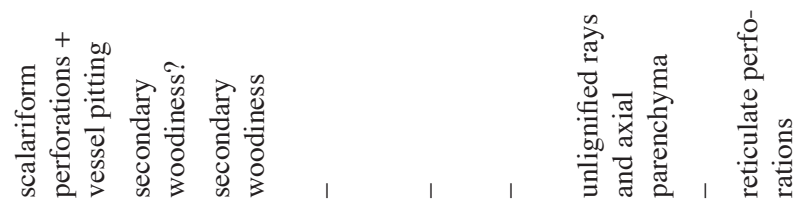

\begin{tabular}{|c|c|c|c|c|c|c|c|c|c|c|}
\hline 1 & 1 & 1 & 1 & 1 & 1 & 1 & 1 & 1 & 1 & \\
\hline 1 & 1 & 1 & 1 & 1 & 1 & I & 1 & 1 & 1 & \\
\hline 1 & I & 1 & 1 & 1 & 1 & 1 & 1 & 1 & 1 & \\
\hline 1 & 1 & 1 & 1 & 1 & 1 & I & 1 & 1 & 1 & \\
\hline+ & + & + & 1 & 1 & + & + & + & + & + & \\
\hline 1 & + & 1 & 1 & + & 1 & 1 & 1 & 1 & 1 & \\
\hline 1 & 1 & 1 & 1 & 1 & 1 & 1 & 1 & 1 & 1 & \\
\hline+ & 1 & 1 & 1 & 1 & 1 & 1 & 1 & 1 & 1 & \\
\hline $\begin{array}{l}\text { P } \\
\text { I }\end{array}$ & - & I & $\stackrel{I}{I}$ & $\begin{array}{l}\underset{\mathbb{I}}{\hat{I}} \\
\stackrel{I}{I}\end{array}$ & $\underset{I}{I}$ & $\begin{array}{l}\stackrel{0}{1} \\
\mathfrak{d} \\
\stackrel{-}{-}\end{array}$ & $\begin{array}{l}\widehat{\underbrace{}} \\
\stackrel{1}{1} \\
\stackrel{1}{-}\end{array}$ & n & 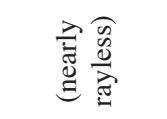 & \\
\hline 1 & 1 & 1 & 1 & 1 & 1 & 1 & 1 & 1 & 1 & \\
\hline 1 & 1 & 1 & 1 & 1 & 1 & + & 1 & 1 & 1 & \\
\hline+ & + & 1 & Æ & Ð & Ð & + & 1 & ક & + & \\
\hline 1 & 1 & 1 & 1 & 1 & 1 & 1 & + & 1 & 1 & \\
\hline 1 & + & + & 1 & 1 & 1 & 1 & + & ક & I & \\
\hline 1 & + & 1 & 1 & + & 1 & I & 1 & ક & + & \\
\hline+ & 1 & + & + & 1 & + & 1 & + & 1 & 1 & \\
\hline+ & 1 & I & + & 1 & + & Ð & 1 & Æ & 1 & \\
\hline 1 & 1 & 1 & a. & ક & 1 & + & 1 & + & 1 & \\
\hline+ & Ð & + & $\sigma$. & $\underset{\sim}{+}$ & $\underset{\sim}{+}$ & + & $\stackrel{\varphi}{\sim}$ & + & + & \\
\hline+ & + & + & a. & + & + & + & ક & Ð & + & 0 \\
\hline I & - & - & $=$ & - & $=$ & $\stackrel{I}{I}$ & I & 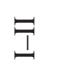 & - & 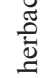 \\
\hline 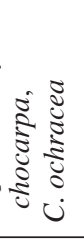 & ̋ँ & $\stackrel{\Xi}{\stackrel{\Xi}{E}}$ & 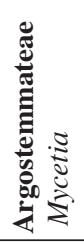 & 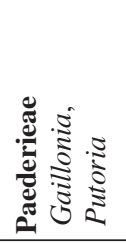 & 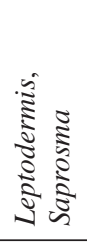 & 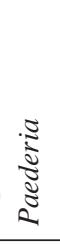 & $\begin{array}{c}\frac{\sqrt{2}}{0} \\
0 \\
0 \\
0\end{array}$ & 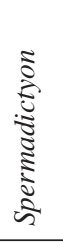 & 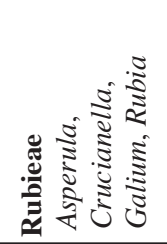 & 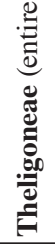 \\
\hline
\end{tabular}




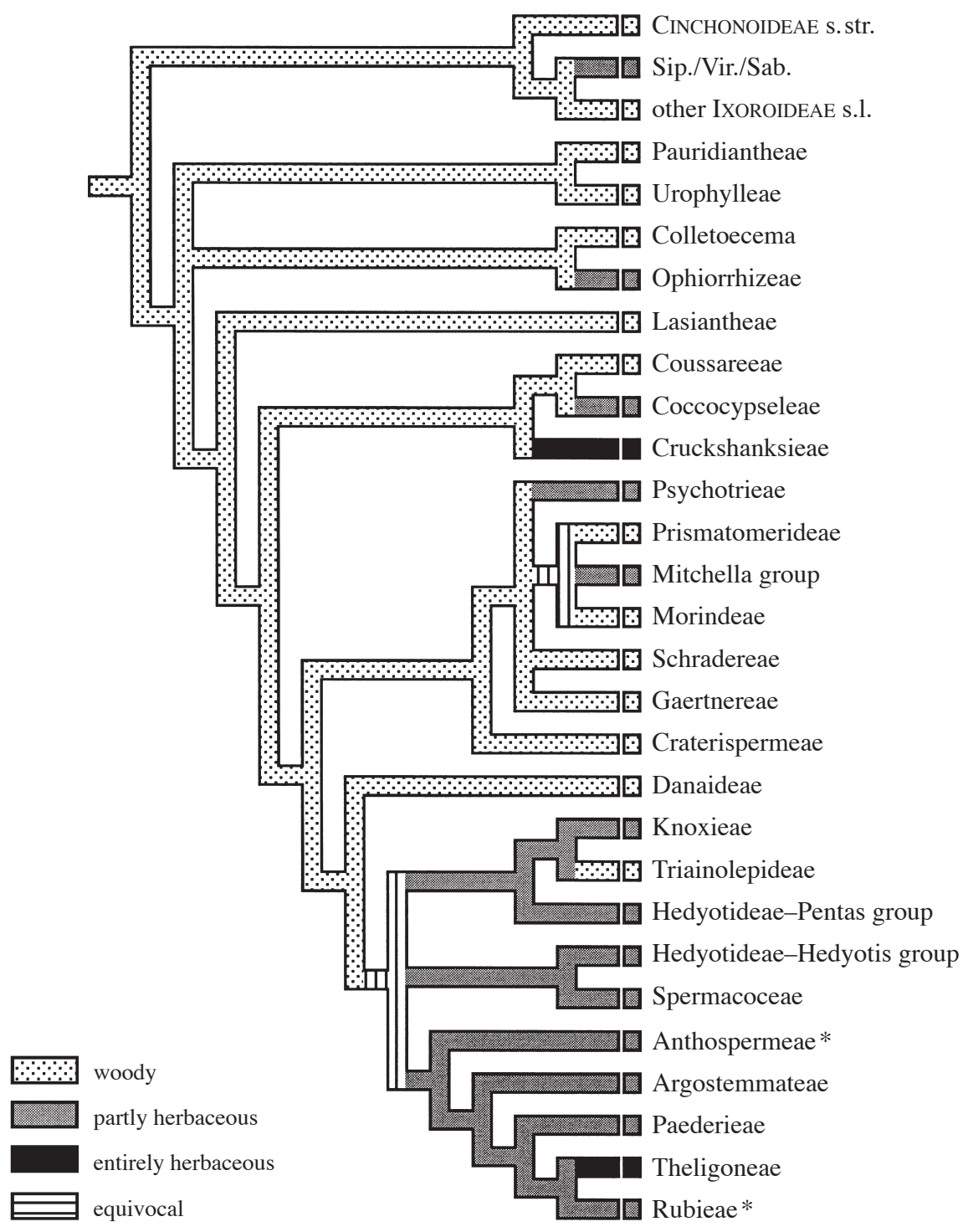

Fig. 63. Woodiness and herbaceousness plotted on a hypothetical tree of the Rubiaceae based on the hypothetical tree in Fig. $3 ;^{*}=$ secondary woodiness is likely in some species; Sip./Vir./ Sab. $=$ Sipaneeae $/$ Virectarieae/Sabiceeae.

Entirely herbaceous taxa are found in Cruckshanksieae and Theligoneae, while the other include herbs and shrubs.

Wood type I is most common in the Rubioideae, but type II appears to have evolved in more than one group (Fig. 64). Tribes that show almost exclusively type II are: 1) Coussareeae and Coccocypseleae, 2) Psychotrieae and Damnacanthus (Mitchella group), and 3) most species of Argostemmateae and Paederieae. 


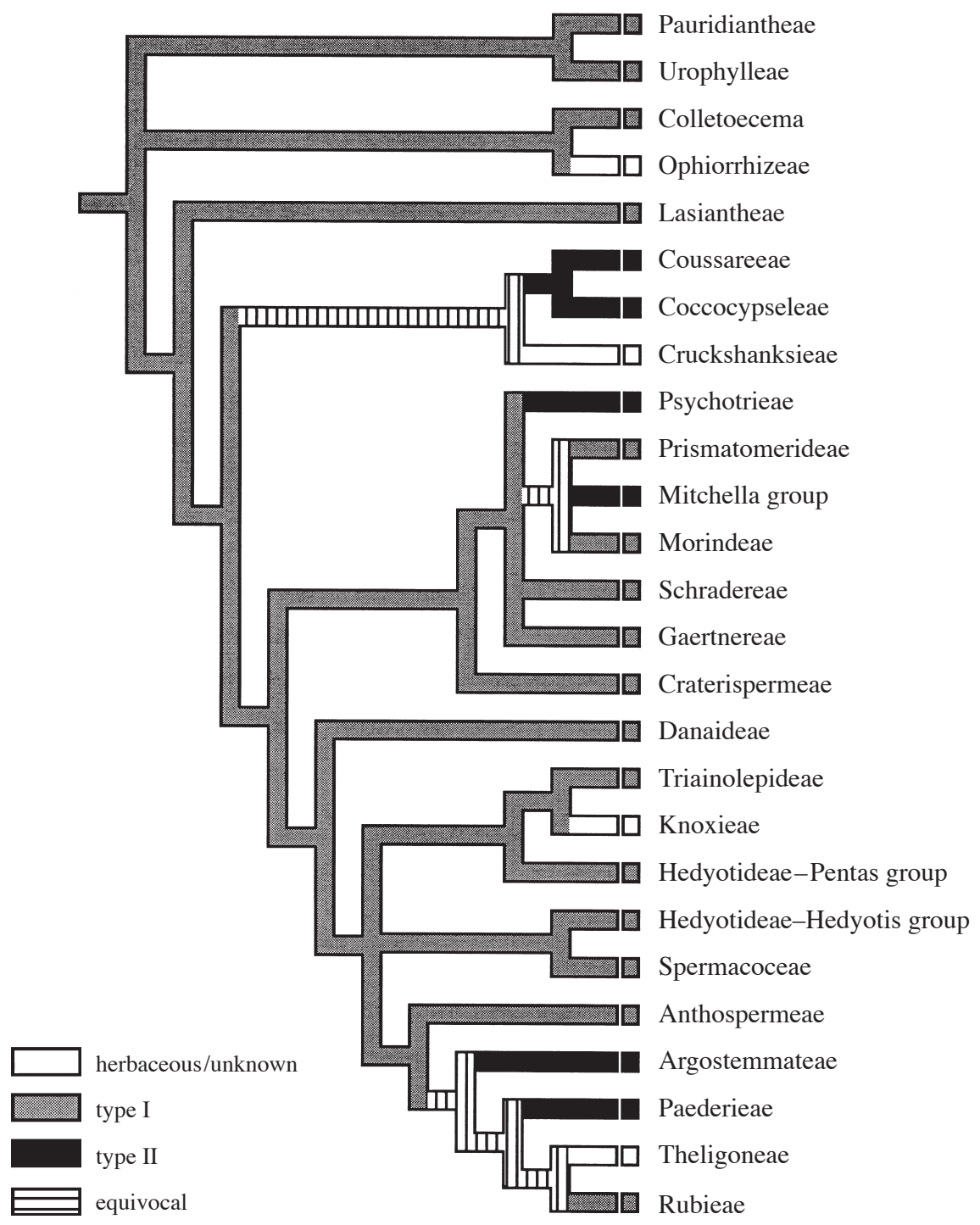

Fig. 64. Wood types plotted on the Rubioideae (part of the hypothetical tree in Fig. 3).

An unusual wood anatomical feature that was reported for the first time by Ohtani (1986) occurs in some basal groups of the Rubioideae. He illustrated the presence of vestures that are associated with helical thickenings in axial parenchyma cells of Lasianthus. This feature appears to characterise other basal Rubioideae, especially Pauridiantheae, Urophylleae, and Lasiantheae (Lasianthus, Trichostachys) (Jansen et al. 2001). Helical thickenings in axial parenchyma cells represent a unique feature in Rubiaceae (not known from other representatives) and are rare in the dicotyledons. The taxonomic value of this character, however, should be interpreted with caution, 
since helical thickenings in axial parenchyma cells are only rarely present in a single wood section and can easily be overlooked.

Many authors argued that Urophylleae and Pauridiantheae, which were separated on the basis of floral and phytogeographical features by Bremekamp (1966), should be merged again (e.g. Bremer \& Manen 2000). Wood anatomy confirms this close relationship, but gives no indication for merging or splitting the two tribes.

The taxonomic position of the genus Colletoecema was investigated in detail by Piesschaert et al. (2000a). The wood structure of this genus corroborates that this genus should be excluded from the Psychotrieae since there are major differences in fibre type, axial parenchyma and vessel arrangement. Similarly, wood type I and differences in gynoecial and fruit structure illustrate that the small neotropical genus Pagameopsis is not a member of the Psychotrieae (Piesschaert et al. in press).

The genus Coccocypselum is entirely herbaceous. In addition to macromolecular data, support for an extended tribe Coccocypseleae was presented by Piesschaert et al. (2000b), who added the woody genera Hindsia and Declieuxia in the tribe. The wood structure of these two genera (type II) supports the position of Coccocypseleae as sister group of the Coussareeae. The latter tribe is characterised by septate libriform fibres and very high multiseriate rays, but stands apart from the other Rubioideae by the occurrence of scanty paratracheal parenchyma (Jansen et al. 2001). Bremer and Manen (2000) merged Coccocypseleae and Coussareeae into Coussareeae sensu lato. Quantitative differences in the wood structure mainly reflect differences in the habit. While the Coussareeae comprise trees and large shrubs (from 2 up to $10-18 \mathrm{~m}$ high), Declieuxia and Hindsia consist of shrubs (up to $1.5 \mathrm{~m}$ ) or perennial herbs, and Coccocypselum only contains creeping herbs.

Banded parenchyma is present in few taxa of the Rubioideae. This type of axial parenchyma is most frequent in the rather basal taxa of the Psychotrieae alliance: Craterispermeae, and Gaertnereae, and to a certain degree in Schradereae and Morindeae. If the Psychotrieae are considered as the most derived group in this clade, one may suggest that the axial parenchyma has developed from banded to diffuse-inaggregates, scanty paratracheal parenchyma and total absence. The lianescent habit of some Schradereae, Morindeae (especially Morinda and Gynochtodes) presumably explains the variation in axial parenchyma: wide bands are characteristic of lianas and parenchyma that is diffuse or diffuse-in-aggregates is found in non-lianescent species (Jansen et al. 2001). The presence of parenchyma bands in Colletoecema (Piesschaert et al. 2000a) may indicate a relationship with the Psychotrieae alliance. Based on molecular data, it has become clear that the genera Gaertnera and Pagamea should best be placed in a separate tribe Gaertnereae instead of a subtribe Gaertnerinae in the Psychotrieae (Jansen et al. 1996, 1997a). Since one wood type is usually constant within a single tribe of the Rubiaceae, a separate tribe Gaertnereae best reflects the wood anatomical variation.

All Hedyotideae studied share most features of wood type I, but vessels are rather frequently arranged in radial multiples (e.g. Oldenlandia, Carphalea, Hedyotis) or even in a more or less diagonal pattern (e.g. Placopoda). The tendency to form diagonal patterns of vessels is most distinctly observed in Triainolepis and in Placopoda, but it is possible that these have been caused by similar, dry environmental condi- 
tions. Prismatic crystals are reported in ray cells and/or axial parenchyma cells of Oldenlandia, Placopoda and Pentas. The distribution of crystals within the Hedyotideae as well as the small number of taxa studied does not allow meaningful systematic conclusions. We therefore do not separate the genera listed in Table 5 into two groups (Hedyotis group and Pentas group) as illustrated in our hypothetical trees. Furthermore, Carphalea (Pentas group) is suggested to be closely related to Placopoda, a monospecific genus endemic to Socotra. Mineral inclusions seem to distinguish both genera: large idioblasts filled with raphides occur in Carphalea, while prismatic crystals are observed in Placopoda. However, a possible close affinity between Carphalea and Triainolepis is supported by the raphides in thick-walled, elongated sacs of ray parenchyma cells (Puff 1988).

Wood type I and fibre-tracheids characterise most representatives of the Anthospermeae. The genus Anthospermum wood anatomically resembles Nenax by the presence of faint rays, which are hardly recognisable on longitudinal sections. As already mentioned above, the genus Coprosma is heterogeneous. The wood of Coprosma shows considerable variation with respect to vessel arrangement, fibre type, perforation plates, intervessel pitting, ray size and heigth, and axial parenchyma distribution. We suggest that at least part of this variation can be explained by the presence of paedomorphic features (see below).

According to Koek-Noorman and Puff (1983), the tribe Paederieae is characterised by wood type II. However, there are several exceptions. Wood type I is more prominent in Gaillonia, Putoria, and Plocama. Koek-Noorman and Puff (1983) mentioned that wood anatomy supports the close affinity between these genera. Since secondary woodiness has possibly developed in some of these taxa (especially Putoria), the wood anatomical similarity may also be a result of paedomorphic characters. The several "unusual" characters of Paederia can obviously be linked to the lianescent habit of the genus: banded parenchyma anastomosing with multiseriate rays, unlignified ray parenchyma in multiseriate rays, very wide rays up to 10 cells wide, and two sizes of vessels (widest vessels up to $400 \mu \mathrm{m}$ ). Unlignified parenchyma in the Rubiaceae is only reported in the genera Schradera and Paederia and an association with the lianescent habit is unclear (Koek-Noorman \& Puff 1991). Other lianas in Rubiaceae (e.g. Uncaria, Rutidea, Mussaenda, Coptosapelta, Aoranthe) do not show unlignified parenchyma.

As suggested by Koek-Noorman (1976) and Carlquist (1992), secondary woodiness has developed in the tribe Rubieae, especially in the representatives of this herbaceous clade that have radiated into more moderate (frost-free) climates (e.g. Asperula, Crucianella, Galium, Rubia). Most remarkable in these species is the predominance of erect ray cells or near raylessness, which has been related with Carlquist's theories on paedomorphosis and insular woodiness (Carlquist 1962, 1969). Koek-Noorman (1976) demonstrated that for Rubia fruticosa the combination of the following conditions may explain raylessness: 1) a limited cambial activity, 2) short fusiform cambial initials, so that there is no great difference between length of fusiform and ray initials, and 3) juvenilism or paedomorphosis. In fact, a length-on-age curve for axial elements of Rubia fruticosa has demonstrated that juvenilism is most likely. This means that there are juvenile characters in the wood of the Rubieae as a result of a shift from 
the primary to the secondary xylem (paedomorphosis). Examples are the scalariform perforation plates as observed in Crucianella. The scalariform intervessel pitting as reported for instance in Coprosma ochraceae, can also result from paedomorphosis or juvenilism as demonstrated by Carlquist (1962). Carlquist (1992; see his figure 6) also noticed for the first time storied wood structure in Galium catalinense, which is not reported in other members of Rubiaceae.

Carlquist (1992) stressed that perennial species of Galium occur in frost-free climates, such as southern California, which allow them to develop a moderate amount of wood. The ultimate proof, however, would be to use DNA evidence in order to evaluate the likelihood of secondary woodiness in these groups. The molecular results of Natali et al. (1996) do not allow such final confirmation, but the wood anatomical data of the Rubiaceae do provide excellent information that evolution towards herbaceousness has occurred in the family, and that in a number of the derived clades of the Rubioideae, secondary woodiness has occurred.

Within the Anthospermeae, secondary woodiness is also likely. Indications for secondary woodiness in Anthospermum are: 1) absence of rays or faint rays in several species of Anthospermum, 2) short vessel elements (low F/V ratio), and 3) short parenchyma strands (1-3 cells high). This can be explained by elongated ray initials and short fusiform cambial initials. According to Koek-Noorman and Puff (1983), the species of Anthospermum that most likely show primary woodiness are closely related and share the occurrence in Afromontane vegetation. In contrast, the presumed secondarily woody species are centred in the Cape Floral Kingdom and in drier parts of Madagascar.

\section{Genera incertae sedis}

The genus Jackiopsis (wood type I) shows a number of unusual features unique in the Rubiaceae (e.g. intra-ovarian trichomes). Following Puff and Igersheim (1994b), the genus is probably best placed in a tribe of its own. A relationship with Carphalea (Hedyotideae) was previously suggested by Baillon (1878). Contrary to Carphalea, there are no large idioblasts filled with raphides in the wood of Jackiopsis. The axial parenchyma distribution, which is diffuse to diffuse-in-aggregates and scanty paratracheal, agrees with the overall type in the Hedyotideae, but this feature is also found in other clades of the Rubioideae.

The genera Ariadne and Phyllomelia were recently included in the Rondeletieae (Delprete 1999). Wood type I of the two genera agrees with other genera of the Rondeletieae sensu Rova (1999) (Acunaeanthus, Dendrosipanea, Mazaea and Rondeletia). Another similarity of Ariadne and Phyllomelia with the Rondeletieae is the absence of mineral inclusions in the wood.

Although the presence of $\mathrm{Al}$ hyperaccumulation and raphides in Coptosapelta may indicate a position within or near the Rubioideae, this genus falls outside all three rubiaceous subfamilies in most molecular analyses. The unique pollen morphological features (Huysmans 1993) as well as the occurrence of T-shaped trichomes (Robbrecht 1977) seem to indicate that Coptosapelta may even not belong to the Rubiaceae. A small wood sample of Coptosapelta examined by us showed the presence of fibretracheids with bordered pits on radial and tangential fibre walls, solitary vessels, uni- 


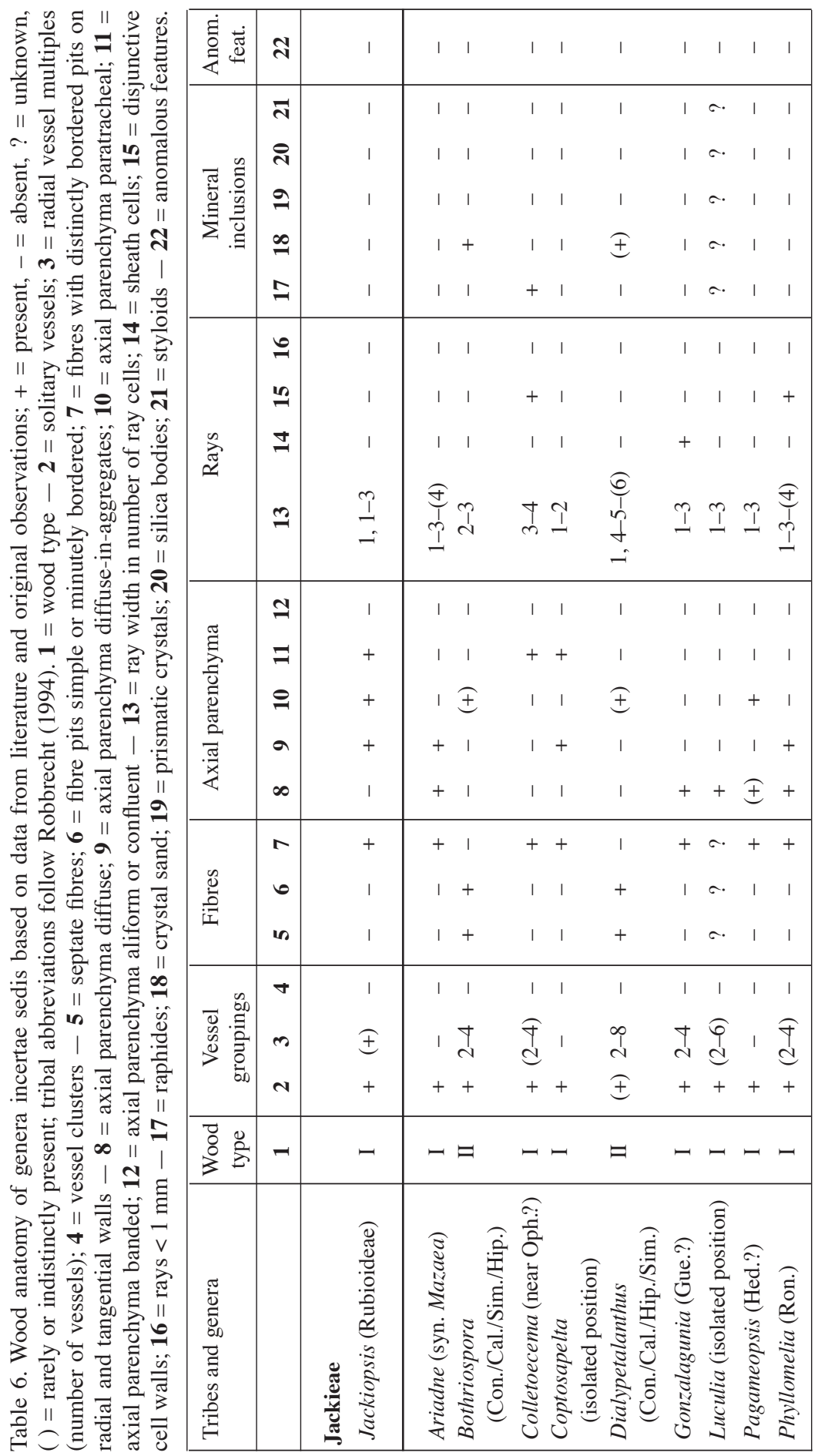


or biseriate rays and a lack of mineral inclusions. Although it is difficult to classify the axial parenchyma distribution in the juvenile wood sample studied, we believe that it is banded and diffuse-in-aggregates. The presence of parenchyma bands is probably an adaptation to the lianescent habit of Coptosapelta. The wood anatomy gives no indication for exclusion of the genus from the Rubiaceae.

Several genera that are listed in Table 6 have been discussed above: Bothriospora and Dialypetalanthus (Ixoroideae s.l. with wood type II), Colletoecema (basal position in Rubioideae), Pagameopsis (Rubioideae, Lasiantheae or Hedyotideae), and Phyllomelia (Rondeletieae).

\section{Notes on mineral inclusions in wood of Rubiaceae}

Based on their form, size and chemical composition, mineral inclusions are frequently considered to be valuable taxonomic markers in systematic anatomy. Although the occurrence of these structures should also be investigated outside the secondary xylem, e.g. in tissues of leaf, bark or fruit, the following discussion is mainly restricted to our observations in wood.

It is well known that the family Rubiaceae shows a wide variation of calcium oxalate crystals in all tissues, including secondary xylem (e.g. Robbrecht 1988). Two crystal types are very common in Rubiaceae and appear to be mutually exclusive, viz. raphides and crystal sand. Prismatic crystals are also present in numerous taxa, but the presence of styloids, druses or silica bodies is restricted to a smaller number of taxa. Crystals in wood occur most frequently in ray and/or axial parenchyma cells. The crystal-containing cells or idioblasts are distinguished in some species (e.g. Triainolepis, Ixora, Versteegia) by their larger size, and in others (e.g. Randia exaltata) by the enhanced thickening of their walls.

We suggest that most crystals are composed of calcium-oxalate, since this is the most common crystal type in plants. However, we did not identify crystals in Rubiaceae as oxalate on the basis of precise methods, such as SEM with an X-ray energy dispersive spectrometer (e.g. Taniguchi et al. 1982; Furuno \& Côté 1983). Crystals of other Ca salts or organic compounds may occur in addition to oxalate crystals.

\section{Raphides}

Raphides are defined as bundles of needle-shaped crystals and it is well known that the distribution of this crystal type characterises all Rubioideae s. 1. Bremekamp's (1966) subfamily was essentially based on the presence of this crystal type. Robbrecht (1988), however, pointed out not to attribute too great an importance to this character since the delimitation of a subfamily on the basis of a single character would seem artificial. Present insights, nevertheless, reestablish the taxonomic value of this character to a great extent. Without studying any material, Bremer and Manen (2000), on the one hand, suggested that Raritebe appears to be the first report of a genus without raphides in Rubioideae. Our observations of Raritebe, however, have clearly illustrated this crystal type in parenchyma cells around the vascular bundles in leaves. On the other hand, raphides have most likely originated twice during the evolution of the Rubiaceae, namely in the Rubioideae and in the closely related tribes Hamelieae and Hillieae (see below). 


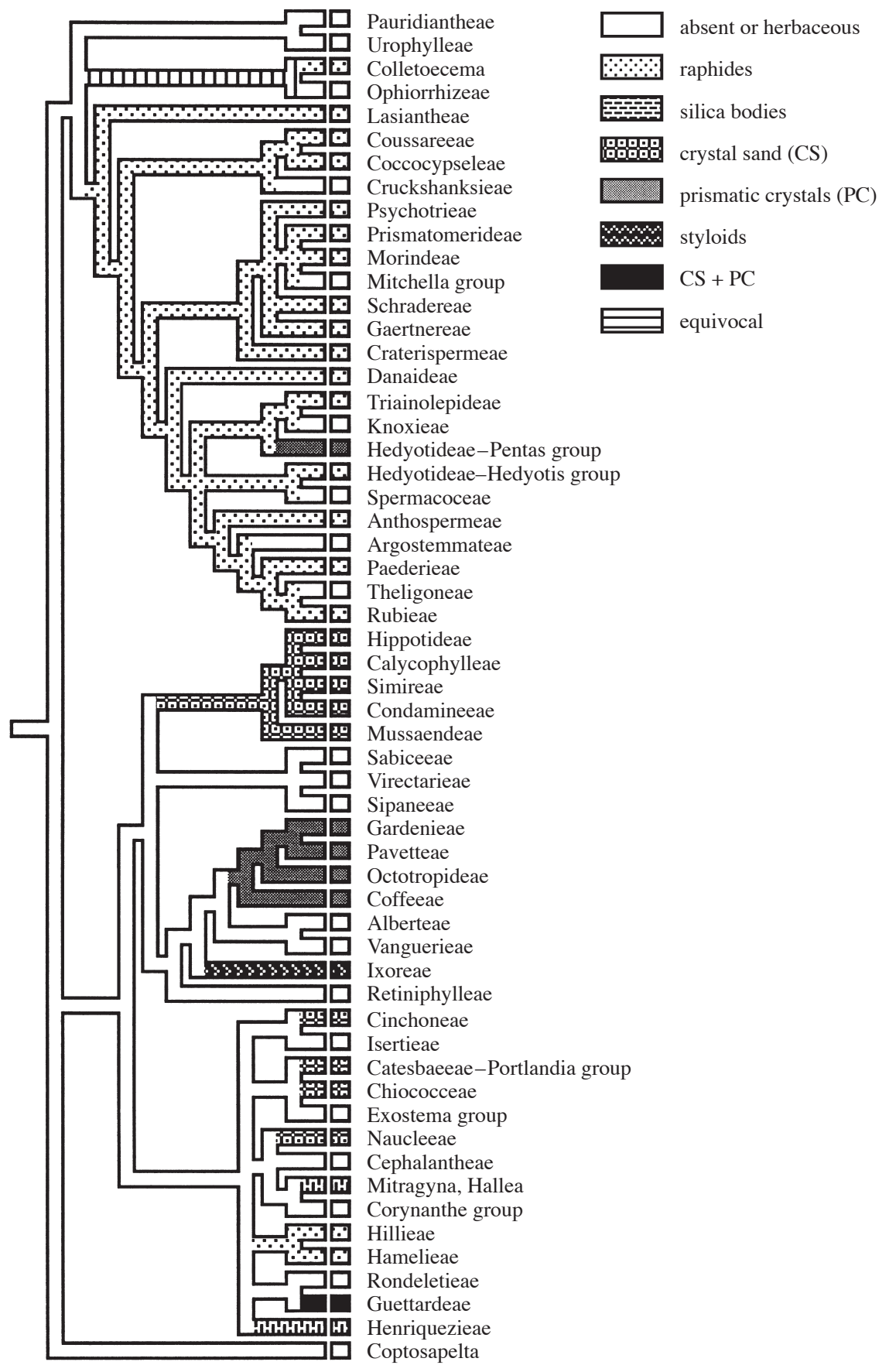

Fig. 65. The distribution of mineral inclusions in the secondary xylem plotted on the hypothetical tree given in Fig. 3. The Catesbaeeae-Catesbaea group is omitted since no data are available for this group. 
We have found raphides in the wood of all tribes of the Rubioideae except for several taxa (Pauridiantheae, Urophylleae, Ophiorrhizeae, Damnacanthus, Knoxieae, and Argostemmateae) (Fig. 65). Raphides, however, do occur in these tribes, but in tissues outside the secondary xylem (e.g., Fig. 53). Hence, the inclusion of the tribes Pauridiantheae, Urophylleae (Cinchonoideae sensu Robbrecht 1988) and Knoxieae and Craterispermeae (Antirheoideae sensu Robbrecht 1988) in the Rubioideae s.l. fits well with the distribution of raphides. Therefore, the absence of raphides in the wood should be interpreted with caution. In general, mineral inclusions are less frequently found in wood than in parenchyma cells of the pith, leaf or bark. Nevertheless, the presence and quantity of raphides in rubiaceous wood can be an important character for phylogenetic purposes. Genera in which raphides are very common in the wood are for instance Craterispermum, Coussarea, Faramea, Gaertnera, and Pagamea.

Outside the Rubioideae, raphides are present in the related tribes Hamelieae and Hillieae, and a few other genera. The presence of raphides in the enigmatic genus Coptosapelta was already observed by Solereder (1893) and confirmed by Fukuoka (1980: see his figure 19B). Raphides are also observed in Steenisia by Bremer (1984), a genus placed in the subfamily Rondeletieae. However, Rova (1999) excluded Steenisia from the Rondeletieae and proposed a position in Hamelieae. Besides the presence (although very rare in Steenisia) of raphides, arguments for this placement may be similarities in exotesta ornamentation and a stalked placenta which is similar to Deppea. Much more striking is that Robbrecht (1986) observed raphides in fruit tissues of a single specimen of Argocoffeopsis (Ixoroideae, Coffeeae). Likewise, we observed small needle-like crystals in the pith parenchyma of the stem of Argocoffeopsis eketensis. In our opinion, it is not certain whether these mineral inclusions in Argocoffeopsis really concern true raphides. Since they do not appear to be a constant and characteristic feature in all specimens of Argocoffeopsis examined by us, one cannot exclude the possibility that these "raphides" are an accidental phenomenon of traumatic origin of some kind.

A next question might be which conditions in the cells of Rubioideae or Hamelieae and Hillieae cause deposit in the size of needles? Raphides generally are monoclinic and low $\mathrm{pH}$ (4.4) was concluded to favour the monoclinic form of oxalate crystals, while higher $\mathrm{pH}$ conditions favour the tetragonal form (Pfeiffer 1925). Indeed, raphides were identified as monoclinic crystal forms (whewellite) in Psychotria punctata (Franceschi \& Horner 1979), and in Morinda and Hamelia (Scurfield et al. 1974). It is exceptional to find both monohydric and trihydric crystals occurring together in the same plant (Pobéguin 1943; Metcalfe \& Chalk 1983). Remarkably, the occurrence of raphides in Rubiaceae is obviously related with aluminium hyperaccumulation (Jansen et al. 2000a, b). Chenery (1948) concluded that a low cell sap acidity ( $\mathrm{pH}$ 3.6-5.2) very frequently characterises aluminium plants too. It should nevertheless be stressed that the relationship between the occurrence of raphides and aluminium hyperaccumulation needs further investigation. Many taxa that possess raphides do not hyperaccumulate aluminium, e. g. a large number of monocotyledons.

\section{Crystal sand}

Crystal sand is a term applied to accumulations of minute, variously shaped prismatic crystals resembling sand when viewed under the microscope. They are com- 
mon in only few dicotyledonous families, viz. Amaranthaceae, Solanaceae, and Rubiaceae (Metcalfe \& Chalk 1983). These crystals are generally trihydric. Within the Rubiaceae, crystal sand is very common in the wood of numerous taxa of the Ixoroideae s.l. (except the core Ixoroideae) and to a lesser extent in the Cinchonoideae s. str. The feature is not observed in any representative of the Rubioideae.

\section{Prismatic crystals}

Besides raphides and crystal sand, other crystals are less common in Rubiaceae and share a restricted distribution. Prismatic crystals are characteristic of wood of most core Ixoroideae s. str. (Coffeeae, Gardenieae, Octotropideae), but there are also reports of this crystal type in some Rubioideae (Schradera, and three genera of the Hedyotideae). The distribution of prismatic crystals in the Hedyotideae, Guettardeae and the genus Rondeletia needs verification and further examination.

\section{Other mineral inclusions}

Druses or cluster crystals are loosely aggregated crystals in more or less spherical groups with few to many components. They are one of the most common crystal types amongst dicotyledons. Since they are much more common outside the secondary xylem, a discussion of this crystal type in Rubiaceae is beyond the scope of this preliminary survey. The taxonomic implications of the occurrence of styloids and silica bodies are discussed in the taxonomic section above.

\section{Comparison of the Rubiaceae with allied families}

The wood structure of the Rubiaceae agrees well with the other families of the Gentianales sensu APG (1998). Wood features common in the families include: simple perforation plates, fibre-tracheids, vestured pits and heterogeneous rays (type II A or II B). Most noteworthy is the lack of intraxylary phloem in Rubiaceae, since this feature occurs in all other families of the Gentianales (e.g. Carlquist 1992).

The order Garryales sensu APG, including Aucubaceae, Eucommiaceae, Garryaceae and Oncothecaceae, takes a basal position within the euasterids I (APG 1998; Soltis et al. 2000). The wood anatomy of these families is characterised by mostly solitary vessels (rarely in multiples or clusters), scalariform perforation plates (except for Eucommia), opposite to alternate (rarely scalariform) intervessel pitting, nonvestured pits and distinct helical thickenings throughout vessel elements in Aucuba, Eucommia and Garrya (Tippo 1940; Moseley \& Beeks 1955; Baas 1975; Carpenter \& Dickison 1976; Noshiro \& Baas 1998). Moreover, axial parenchyma is scanty paratracheal (especially in Aucuba and Oncotheca) and diffuse or diffuse-in-aggregates. Fibre-tracheids with distinctly bordered pits in both radial and tangential walls occur in Eucommia, Garrya and Oncotheca, but minutely bordered pits in radial walls and occasionally septate fibres are found in Aucuba. Hence, there are major differences between the Garryales and most representatives of the Gentianales with respect to the structure of the secondary xylem. 


\section{CONCLUSIONS}

Although wood anatomy of the Rubiaceae exhibits a relatively narrow range of structural variability, it constitutes an important set of taxonomical characters when attempting to reconstruct an evolutionary scenario of the Rubiaceae. The two main wood types occurring in Rubiaceae are powerful tools that should be used as important elements in any data matrix of the family. In fact, wood anatomical data especially allow to confirm or negate already existing or proposed relationships among rubiaceous tribes and genera rather than to hypothesise precise taxonomic positions. Thus, wood anatomy can be used as an independent test of systematic hypothesis; relationships that are not consistent with respect to their wood anatomical pattern should be seriously questioned.

Since wood anatomy only partly resolves some taxonomic problems in the Rubiaceae, it is not possible to propose an alternative formal taxonomic classification of the Rubiaceae, containing a significantly higher degree of monophyly of the constituting groups than the current classifications. We need a much more extensive sampling of taxa for molecular systematics to increase our understanding of the phylogeny of the Rubiaceae since many relationships are obscure and resolution in several groups is poor. Also, taxa taken for monophyletic or phylogenetically closely related may prove not to be so. More importantly, combined molecular and structural analyses are required since both can contribute meaningfully to interpreting evolutionary relationships within the Rubiaceae.

Conclusions drawn from this wood anatomical study can be summarised in the following points from subfamilial level down to generic level.

\section{Subfamilial level conclusions}

- Although there is no wood anatomical support for any of the three subfamilies Rubioideae, Ixoroideae s.1. or Cinchonoideae s. str, there is an overall agreement between the two rubiaceous wood types and recent phylogenetic hypotheses. Wood type I is most widespread and characterises for instance the core Ixoroideae. Wood type II shows many parallel origins and is demonstrated to characterise the following groups: 1) Hillieae and Hamelieae, 2) Cinchoneae, 3) Ixoroideae s.l. excluding the core Ixoroideae, 4) Coussareeae and Coccocypseleae, 5) Psychotrieae, 6) Argostemmateae, and 7) Paederieae.

- Raphides are most likely to have evolved independently in two related tribes of the Cinchonoideae (Hillieae and Hamelieae) and in the Rubioideae. The raphide-bearing, isolated genus Coptosapelta needs further consideration and investigation.

- The herbaceous habit has originated several times in the family, but most particularly in the derived clades of the Rubioideae. There are strong indications for cases of secondary woodiness in the Rubieae and Anthospermeae.

\section{Tribal level conclusions}

- The wood anatomical heterogeneity of the Guettardeae is exceptional compared to the general homogeneity at the tribal level. A thorough study is needed addressing the problem of the taxonomic delimitation of the Guettardeae as well as a revision of its genera. 
- Henriquezieae take an isolated position within the Rubiaceae on the basis of aliform to confluent axial parenchyma and uniseriate, low rays.

- Wood type II confirms the close relationship between the following tribes: 1) Hillieae and Hamelieae, 2) Coussareeae and Coccocypseleae, 3) Hippotideae, Simireae, Condamineeae, Calycophylleae and possibly Mussaendeae. Other tribes in which wood type II is represented include Psychotrieae, Argostemmateae, Paederieae, Cinchoneae, and part of the Guettardeae.

- Delprete's (1999) very wide concept of the Rondeletieae is contradicted. While many Rondeletieae are members of the Cinchonoideae s. str., the former Condamineeae appertain to Ixoroideae s.1.

- Axial parenchyma bands confirm possible affinities between 1) Craterispermeae, Gaertnereae, Schradereae and Morindeae, and 2) Retiniphylleae and Ixoreae.

- Prismatic, solitary crystals are characteristic of most core Ixoroideae: Gardenieae (incl. Aulacocalyceae), Coffeeae, Octotropideae, and to a lesser extent Pavetteae.

- Crystal sand is characteristic of the Ixoroideae s.l. that show wood type II.

- Helical thickenings in axial parenchyma cells are an unusual feature of the secondary xylem that links Pauridiantheae and Urophylleae to Lasianthus and Trichostachys.

- It is better to place Gaertnera and Pagamea in a separate tribe Gaertnereae instead of a subtribe Gaertnerinae in the Psychotrieae.

\section{Generic level conclusions}

- Wood anatomy supports the inclusion of the following genera in the Ixoroideae s.1. with type II: Bathysa, Dialypetalanthus, Elaeagia, Macbrideina, Mastixiodendron, and Warszewiczia.

- Silica bodies support the strong affinity between Platycarpum and Henriquezia as well as between Hallea and Mitragyna.

- Banded parenchyma is suggested to be a synapomorphy for the Alibertia group (Gardenieae).

- Posoqueria can be distinguished from the Gardenieae by several wood anatomical features.

- Wood type I corroborates the recent exclusion of Colletoecema, Lasianthus, and Pagameopsis from the Psychotrieae (wood type II).

- Mussaendopsis (wood type II) should be excluded from the Corynanthe group (wood type I).

- The heterogeneity in the wood structure of Coprosma (Anthospermeae) needs further examination with respect to juvenilism and ecological and geographical considerations.

\section{ACKNOWLEDGEMENTS}

P. Baas and J. Koek-Noorman suggested numerous improvements to the manuscript. We are grateful to Anja Vandeperre for technical assistance with slide preparations, darkroom work and the preparation of the figures. We thank E.A. Wheeler for references on fossil woods of Rubiaceae. The directors and curators of the herbaria $\mathrm{K}, \mathrm{L}, \mathrm{U}, \mathrm{MO}$ and $\mathrm{U}$ are acknowledged for making their specimens available and supplying us generously with study material. Steven Jansen is a postdoctoral 
fellow of the Fund for Scientific Research-Flanders (Belgium) (F.W.O.-Vlaanderen). Research at the Laboratory of Plant Systematics is supported by grants from the Research Council of the K.U. Leuven (OT/01/25) and the Fund for Scientific Research-Flanders (Belgium) (G.104.01).

\section{REFERENCES}

Acevedo, M.M. \& Y. Kikita. 1994. Atlas of Peruvian woods. National Agrarian University La Molina, Peru \& Nagoya University, Japan.

Aiello, A. 1979. A reexamination of Portlandia (Rubiaceae) and associated taxa. J. Arnold Arbor. 60: 38-126.

Andersson, L. 1995. Tribes and genera of the Cinchoneae complex (Rubiaceae). Ann. Missouri Bot. Gard. 82: 409-427.

Andersson, L. \& C. Persson. 1991. Circumscription of the tribe Cinchoneae (Rubiaceae) A cladistic approach. Pl. Syst. Evol. 178: 65-94.

Andersson, L. \& J.H.E. Rova. 1999. The rps16 intron and the phylogeny of the Rubioideae (Rubiaceae). Pl. Syst. Evol. 214: 161-186.

Andreasen, K., B.G. Baldwin \& B. Bremer. 1999. Phylogenetic utility of the nuclear rDNA ITS region in subfamily Ixoroideae (Rubiaceae): comparisons with cpDNA rbcL sequence data. Pl. Syst. Evol. 217: 119-135.

Andreasen, K. \& B. Bremer. 1996. Phylogeny of the Ixoroideae (Rubiaceae). In: E. Robbrecht, C. Puff \& E. Smets (eds.), Second International Rubiaceae Conference, Proceedings. Opera Bot. Belg. 7: 119-138.

Andreasen, K. \& B. Bremer. 2000. Combined phylogenetic analysis in the Rubiaceae-Ixoroideae: morphology, nuclear and chloroplast DNA data. Amer. J. Bot. 87: 1731-1748.

APG (Angiosperm Phylogeny Group). 1998. An ordinal classification for the families of flowering plants. Ann. Missouri Bot. Gard. 85: 531-553.

Ayensu, E.S. \& A. Bentum. 1974. Commercial timbers of West Africa. Smithsonian Contrib. Bot. 14: 1-69.

Baas, P. 1975. Vegetative anatomy and the affinities of Aquifoliaceae, Sphenostemon, Phelline, and Oncotheca. Blumea 22: 311-407.

Baillon, H. 1878. Sur l'organisation et les affinités du Jackia. Bull. Mens. Soc. Linn. Paris 1: $185-188$.

Barajas-Morales, J. \& C.L. Gomez. 1989. Anatomia de maderas de Mexico: especies de una selva baja caducifolia. Univ. Nacional Autonoma de Mexico, Inst. Biol. Publ. 1: 94-96.

Barros, C.C.F. \& C.H. Callado. 1997. Timbers of the Atlantic rain forest. Wood anatomy of species from remnant forests in Rio de Janeiro State Brazil. Volume 1. Jardim Botanico de Rio de Janeiro, Brazil.

Beeckman, H. \& S. Jansen. 1995. Growth rings in wood of tropical Rubiaceae. In: E. Robbrecht, E. Smets \& C. Puff (eds.), 2nd International Rubiaceae Conference, Programme \& Abstracts. Scripta Bot. Belg. 11: 72.

Brazier, J.D. \& G.L. Franklin. 1961. Identification of hardwoods, a microscopic key. Forest Products Research Bulletin 46. Her Majesty's Stationery Office, London.

Bremekamp, C.E.B. 1952. The African species of Oldenlandia L. sensu Hiern et K. Schumann. Verh. Kon. Ned. Akad. Wetensch., Afd. Natuurk., 2. Sect. 18: 1-297.

Bremekamp, C.E.B. 1966. Remarks on the position, the delimitation and the subdivision of the Rubiaceae. Acta Bot. Neerl. 15: 1-33.

Bremer, B. 1984. The genus Steenisia (Rubiaceae) and its taxonomic position. Nordic J. Bot. 4: 333-345.

Bremer, B. 1992. Phylogeny of the Rubiaceae (Chiococceae) based on molecular and morphological data. Useful approaches for classification and comparative ecology. Ann. Missouri Bot. Gard. 79: 380-387. 
Bremer, B. 1996. Phylogenetic studies within Rubiaceae and relationships to other families based on molecular data. In: E. Robbrecht, C. Puff \& E. Smets (eds.), Second International Rubiaceae Conference, Proceedings. Opera Bot. Belg. 7: 33-50.

Bremer, B., K. Andreasen \& D. Olsson. 1995. Subfamilial and tribal relationships in the Rubiaceae based on rbcL sequence data. Ann. Missouri Bot. Gard. 82: 383-397.

Bremer, B. \& R.K. Jansen. 1991. Comparative restriction site mapping of the chloroplast DNA implies new phylogenetic relationships within the Rubiaceae. Amer. J. Bot. 78: 198-213.

Bremer, B., R.K. Jansen, B. Oxelman, M. Backlund, H. Lantz \& K. Ki-Joong. 1999. More characters or more taxa for a robust phylogeny - case study from the coffee family (Rubiaceae). Syst. Biol. 48: 413-435.

Bremer, B. \& J.-F. Manen. 2000. Phylogeny and classification of the subfamily Rubioideae (Rubiaceae). Plant Syst. Evol. 225: 43-72.

Bremer, B. \& M. Thulin. 1998. Collapse of Isertieae, re-establishment of Mussaendeae, and a new genus of Sabiceeae (Rubiaceae); phylogenetic relationships based on rbcL data. Pl. Syst. Evol. 211: 71-92.

Bridson, D., P. Gasson \& E. Robbrecht. 1980. Phellocalyx, a new tropical African genus in Rubiaceae (Gardenieae). Kew Bull. 35: 315-321.

Brown, F.B.H. 1922. The secondary xylem of Hawaiian trees. Occ. Pap. B. P. Bishop Mus. 8: 217-371.

Burgerstein, A. 1912. Anatomische Untersuchungen argentinischer Hölzer. K. K. Naturhist. Hofm. 26: 26-27.

Carlquist, S. 1962. A theory of paedomorphosis in dicotyledonous woods. Phytomorphology 12: $30-45$.

Carlquist, S. 1969. Wood anatomy of Goodeniaceae and the problem of insular woodiness. Ann. Missouri Bot. Gard. 56: 358-390.

Carlquist, S. 1992. Wood anatomy of sympetalous dicotyledon families: a summary, with comments on systematic relationships and evolution of the woody habit. Ann. Missouri Bot. Gard. 79: 303-332.

Carpenter, C.S. \& W.C. Dickison. 1976. The morphology and relationships of Oncotheca balansae. Bot. Gaz. 137: 141-153.

Carreras, R. \& R. Dechamps. 1995. Anatomia de la madera de 157 especies forestales que crecen en Cuba y sus usos technologicos, historicos y culturales. In: Documentatie Economische Wetenschappen: 90-91. KMMA, Tervuren.

Ceccantini, G.C.T. \& V. Angyalossy-Alfonso. 2000. Perforated ray cells in Bathysa meridionalis (Rubiaceae). IAWA J. 21: 77-82.

Chalk, L., J.B. Davy, H.E. Desch \& A.C. Hoyle. 1933. Twenty West African Timber trees. Clarendon Press, Oxford.

Chenery, E.M. 1948. Aluminium in plants and its relation to plant pigments. Ann. Bot. 12: $121-136$.

Cody, A.M. \& H.T. Horner. 1983. Twin raphides in the Vitaceae and Araceae and a model for their growth. Bot. Gaz. 144: 318-330.

Coulaud, J. 1988. Une nouvelle approch des caractères quantitatifs du bois des Loganiacées. Ann. Sci. Nat., Bot. sér. 13, 9: 37-44.

Coulaud, J. 1989. Comparaison de quelques Loganiacées à l'aide des caractères quantitatifs et qualitatifs de l'anatomie du bois. Can. J. Bot. 67: 872-878.

Darwin, S.P. 1979. A synopsis of the indigenous genera of Pacific Rubiaceae. Allertonia 2: $1-44$.

De Block, P. \& E. Robbrecht. 1997. Duperrea, a most remarkable Rubiaceae from Indochina. Scripta Bot. Belg. 15: 44.

Dechamps, R. 1985. Etude anatomique de bois d'Amérique du Sud. III. Linaceae à Quinaceae. [really Linaceae to Zygophyllaceae]. Ann. Mus. Roy. Afr. Cent. Tervuren, sér. IN-8, Sci. Econ., No. 14. 
De Freitas, M.C.P.G. 1955. Estudo das Madeiras de timor. Mémorias série Botânica III.

Delprete, P.G. 1996. Evaluation of the tribes Chiococceae, Condamineeae and Catesbaeeae (Rubiaceae) based on morphological characters. In: E. Robbrecht, C. Puff \& E. Smets (eds.), Second International Rubiaceae Conference, Proceedings. Opera Bot. Belg. 7: 165-192.

Delprete, P.G. 1998. Notes on calycophyllous Rubiaceae. Part III. Systematic position of the monotypic Mexican genus Cosmocalyx and notes on the calycophyl development. Brittonia 50: 309-317.

Delprete, P.G. 1999. Morphological and taxonomical comparison of the Cuban endemic taxa Ariadne, Mazaea, Phyllomelia and Eosanthe (Rubiaceae, Rondeletieae). Brittonia 51: 217230.

Delprete, P.G. \& M. Nee. 1997. The enigmatic genus Wernhamia S. Moore is a synonym of Simira (Rubiaceae, Rondeletieae). Brittonia 49: 303-308.

Desch, H.E. 1954. Manual of Malayan timbers, Vol. II. In: Malayan For. Rec. 15: 329-762. Malayan Publishing House LTD, Singapore.

Dessein, S., L. Andersson, E. Robbrecht \& E. Smets. 2001a. Hekistocarpa (Rubiaceae): a member of an emended tribe Virectarieae. Plant Syst. Evol. 229: 59-78.

Dessein, S., S. Jansen, S. Huysmans, E. Robbrecht \& E. Smets. 2001b. A morphological and anatomical survey of Virectaria (African Rubiaceae), with a discussion of its taxonomic position. Bot. J. Linn. Soc. 137: 1-29.

Détienne, P. \& P. Jacquet. 1983. Atlas d'identification des bois de l'Amazonie et des régions voisines. Centre Tech. For. Trop., Nogent-sur-Marne.

Détienne, P., P. Jacquet \& A. Mariaux. 1982. Manuel d' identification des bois tropicaux. 3. Guyane française. Centre Tech. For. Trop., Nogent-sur-Marne.

Fay, M.F., B. Bremer, G.T. Prance, M. van der Bank, D. Bridson \& M.W. Chase. 2000. Plastid rbcL sequence data show Dialypetalanthus to be a member of Rubiaceae. Kew Bull. 55: 853-864.

Fernandez, P.G. \& C.M. Peters. 1982. Anillos anuales de crecimiento en cafetos (Coffea arabica L.) y sus usos potenciales. Turrialba 33: 89-91.

Fouarge, J. \& G. Gérard. 1964. Bois du Mayumbe. Publ. Inst. Nat. Etude Agr. Congo, Bruxelles.

Fouarge, J., G. Gérard \& E. Sacré. 1953. Bois du Congo. Publ. Inst. Nat. Etude Agr. Congo, Bruxelles.

Franceschi, V.R. \& H.T. Jr. Horner. 1979. Use of Psychotria punctata callus in study of calcium oxalate crystal idioblast formation. Z. Pflanzenphysiol. 92: 61-75.

Fukuoka, N. 1980. Studies in the floral anatomy and morphology of Rubiaceae IV. Rondeletieae and Cinchoneae. Acta Phytotaxon. Geobot. 31: 65-71.

Fundter, J.M. \& J.H. Wisse. 1977. 40 belangrijke houtsoorten uit Indonesisch Nieuw Guinea (Irian Jaya) met de anatomische en technische kenmerken. Meded. Landbouwhogesch. Wageningen 77: 1-223.

Furuno, T. \& W.A. Côté. 1983. Observation of cell inclusions in Papua New Guinea woods by means of SEM/EDXA. IAWA Bull. n. s. 4: 219-236.

Gasson, P., P. Jarvis \& W. Page. 1998. Wood anatomy of twelve species with potential for reintroduction on Round Island, Mauritius. IAWA J. 19: 393-413.

Gevin, P., J.-Cl. Koeniguer \& Y. Lemoigne. 1971. Les bois fossiles du Dalaat el Admia (région de Tindouf, Algérie). Bull. Soc. Géol. Fr. 13: 386-393.

Gill, L.S. \& J.E. Onuja. 1984. A comparative study of the tracheary elements of some commercial hardwoods of Nigeria. Feddes Repert. 95: 645-655.

Gomes, A.V. \& J.N. Marchiori. 1984. Wood structure of some species of Calycophyllum (Rubiaceae). Proceedings of the Pacific Regional Wood Anatomy Conference. IAWA Bull. n. s. 5: 158.

Gregory, M. 1994. Bibliography of systematic wood anatomy of dicotyledons. IAWA J. Supplement 1, Leiden. 
Gros, J.P. 1990. Études xylotomiques et systématiques de bois fossil cenozoiques de la basse vallée de l'Omo, Éthiopie. Leurs apports à la connaissance des Bignoniaceae, Irvingiaceae, Mimosaceae, Rubiaceae fossiles et à la reconstitution des flores et végétations ligneuses passées. Tome 1, Tome 2. Thèse, L'Université Claude Bernard Lyon I.

Hofmann, E. 1952. Pflanzenreste aus dem Phosphoritvorkommen von Prambachkirchen in Oberösterreich. Palaeontogr. Abt. B Palaeophytol. 92B: 122-183.

Hogeweg, P. \& J. Koek-Noorman. 1975. Wood anatomical classification using iterative character weighing. Acta Bot. Neerl. 24: 269-283.

Huysmans, S. 1993. De pollenmorfologie van de Coptosapelteae (Rubiaceae-Cinchonoideae). Eindverhandeling, Instituut voor Plantkunde, K.U. Leuven.

Huysmans, S., E. Robbrecht, P. Delprete \& E. Smets. 1999. Pollen morphological support for the Catesbaeeae-Chiococceae-Exostema-complex (Rubiaceae). Grana 38: 325-338.

IAWA Committee. 1989. IAWA list of microscopic features for hardwood identification. IAWA Bull. n. s. 10: 219-332.

International Tropical Timber Organisation and Research Institute of Wood Industry. 1991. Identification, properties and uses of some Southeast Asian woods.

James, C.F. 1954. The wood anatomy of timbers found in mangrove associations of the SouthWest Pacific Area. Division of Forest Products, Commonwealth Scientific and Industrial Research Organization.

Jansen, S., P. De Block, H. Beeckman \& E. Smets. 1999. Systematic wood anatomy of the Pavetteae (Rubiaceae, Ixoroideae). Syst. Geogr. Pl. 68: 113-133.

Jansen, S., S. Dessein, F. Piesschaert, E. Robbrecht \& E. Smets. 2000a. Aluminium hyperaccumulation in leaves of Rubiaceae. Ann. Bot. 85: 91-101.

Jansen, S., P. Kitin, H. De Pauw, M. Idris, H. Beeckman \& E. Smets. 1998. Preparation of wood specimens for transmitted light microscopy and scanning electron microscopy. Belg. J. Bot. 131: 41-49.

Jansen, S., F. Lens, S. Ntore, F. Piesschaert, E. Robbrecht \& E. Smets. 2001. Contributions to the systematic wood anatomy of the Rubioideae (Rubiaceae). J. Plant Res. 114: 269-289.

Jansen, S., E. Robbrecht, H. Beeckman \& E. Smets. 1996. Gaertnera and Pagamea: genera within the Psychotrieae or constituting the tribe Gaertnereae? A wood anatomical and palynological approach. Bot. Acta 109: 466-476.

Jansen, S., E. Robbrecht, H. Beeckman \& E. Smets. 1997a. Wood anatomy of the predominantly African representatives of the tribe Psychotrieae (Rubiaceae-Rubioideae). IAWA J. 18: 169-196.

Jansen, S., E. Robbrecht, H. Beeckman \& E. Smets. 1997b. Comparative wood anatomy of African Coffeeae (Rubiaceae-Ixoroideae). Belg. J. Bot. 130: 47-58.

Jansen, S., E. Robbrecht, H. Beeckman \& E. Smets. 2000b. Aluminium hyperaccumulation in the secondary xylem of Rubiaceae. IAWA J. 21: 197-212.

Kanehira, R. 1921. Anatomical characters and identification of Formosan Woods with critical remarks from the climatic points of view. Government of Formosa, Taikohu.

Kirkbride Jr., J.H. 1997. Manipulus rubiacearum. VI. Brittonia 49: 354-379.

Koek-Noorman, J. 1969a. A contribution to the wood anatomy of South American (chiefly Suriname) Rubiaceae. I. Acta Bot. Neerl. 18: 108-123.

Koek-Noorman, J. 1969b. A contribution to the wood anatomy of South American (chiefly Suriname) Rubiaceae. II. Acta Bot. Neerl. 18: 377-395.

Koek-Noorman, J. 1970. A contribution to the wood anatomy of the Cinchoneae, Coptosapelteae and Naucleeae (Rubiaceae). Acta Bot. Neerl. 19: 154-164.

Koek-Noorman, J. 1972. The wood anatomy of Gardenieae, Ixoreae and Mussaendeae (Rubiaceae). Acta Bot. Neerl. 21: 301-320.

Koek-Noorman, J. 1976. Juvenile characters in the wood of certain Rubiaceae with special reference to Rubia fruticosa Ait. IAWA Bull. 3: 38-42. 
Koek-Noorman, J. 1977. Systematische Holzanatomie einiger Rubiaceen. Ber. Deut. Bot. Ges. 90: $183-190$.

Koek-Noorman, J. 1980. Wood anatomy and classification of Henriquezia Spruce, Platycarpum Humb. et Bonpl. and Gleasonia Standl. Acta Bot. Neerl. 29: 117-126.

Koek-Noorman, J. \& P. Hogeweg. 1974. The wood anatomy of Vanguerieae, Cinchoneae, Condamineeae and Rondeletieae (Rubiaceae). Acta. Bot. Neerl. 23: 627-653.

Koek-Noorman, J. \& C. Puff. 1983. The wood anatomy of Rubiaceae tribes Anthospermeae and Paederieae. Pl. Syst. Evol. 143: 17-45.

Koek-Noorman, J. \& C. Puff. 1991. The wood anatomy of Paederia L. (Rubiaceae-Paederieae). In: C. Puff (ed.), The genus Paederia L. (Rubiaceae-Paederieae): a multidisciplinary study. Opera Bot. Belg. 3: 35-40.

Koeniguer, J.C. 1975. "Expéditions paléontologiques au Tchad.” I. Les bois plio-quaternaires du Nord-Tchad (Kolinga, Koro Toro, Angamma). Ann. Paléont., Invert. 61: 177-214.

Kribs, D.A. 1928. The Persaud Collection of British Guiana woods. Trop. Woods 13: 7-46.

Kribs, D.A. 1968. Commercial foreign woods on the American Market. Dover Publications, New York.

Lebacq, L. \& R. Dechamps. 1967. Contribution à un inventaire de forêts du Nord-Kasai. Ann. Mus. Roy. Afr. Centr., Tervuren, sér. IN-8, Sci. Econ., No. 5.

Lecomte, H. 1922. Madagascar. Les bois de la forêt d'Analamazaotra. A. Challamel, Paris.

Lemesle, R. 1947a. La constitution du bois secondaire homogène des Ipécacuanhas. C. R. Acad. Sci., Paris 224: 144-145.

Lemesle, R. 1947b. La constitution anatomique du bois secondaire chez les Ipécacuanhas vrais. Rev. Gén. Bot. 54: 138-152.

Lemoigne, Y. 1978. Flores Tertiares de la Haute Vallée de l'Omo (Ethiopie). Palaeontogr. Abt. B Palaeophytol. 165B: 80-157.

Lens, F., S. Jansen, E. Robbrecht \& E. Smets. 2000. Wood anatomy of the Vanguerieae (Ixoroideae-Rubiaceae), with special emphasis on some geofrutices. IAWA J. 21: 443-455.

Leroy, J.F. 1975. Taxogénétique: étude sur la sous-tribu des Mitragyninae (Rubiaceae-Naucleeae). Adansonia sér. 2, 15: 65-88.

Lomibao, B.A. 1975. Wood anatomy of 9 Rubiaceae species. II. Forpride Digest 4: 70-71.

Lorence, D.H. \& J. D. Dwyer. 1988. A revison of Deppea (Rubiaceae). Allertonia 4: 389-436.

Manen, J.F. \& A. Natali. 1996. The chloroplast atpB-rbcLspacer in Rubiaceae. In: E. Robbrecht, C. Puff \& E. Smets (eds.), Second International Rubiaceae Conference, Proceedings. Opera Bot. Belg. 7: 51-57.

McDowell, T. 1996. Syringantha coulteri (Hooker f.) McDowell, a new combination and remarks on the relationships of the monotypic Mexican genus Syringantha Standley (Rubiaceae). Novon 6: 273-279.

Mennega, A.M.W. \& J. Koek-Noorman. 1973. A comparison of the wood structure of the Rubiaceae and Loganiaceae in relation to the taxonomic position of the genera Gaertnera and Pagamea. Acta Bot. Neerl. 22: 247-248.

Metcalfe, C.R. \& L. Chalk. 1950. Anatomy of the dicotyledons. Clarendon Press, Oxford.

Metcalfe, C.R. \& L. Chalk. 1983. Anatomy of the dicotyledons. Vol. II. Wood structure and conclusion of the general introduction. 2nd Ed. Clarendon Press, Oxford.

Meylan, B. A. \& B.G. Butterfield. 1978. The structure of New Zealand woods. N. Z. Dept. Sci. Ind. Res., Bull. 222, Wellington.

Milanez, F. R. 1936. Antomia do lenho do "Pau Mulato". Arch. Inst. Biol. Veg. 3: 111-129. Miles, A. 1978. Photomicrographs of world woods. Her Majesty's Stationery Office, London.

Moll, J.W. \& H.H. Janssonius. 1926. Mikrogaphie des Holzes der auf Java vorkommenden Baumarten. IV. E. J. Brill, Leiden.

Moseley, M.F. \& R.M. Beeks. 1955. Studies of the Garryaceae. I. The comparative morphology and phylogeny. Phytomorphology 5: 314-346. 
Natali, A., J.-F. Manen, M. Kiehn \& F. Ehrendorfer. 1996. Tribal, generic and specific relationships in the Rubioideae-Rubieae (Rubiaceae) based on sequence data of a cpDNA intergene region. In: E. Robbrecht, C. Puff \& E. Smets (eds.), Second International Rubiaceae Conference, Proceedings. Opera Bot. Belg. 7: 193-203.

Normand, D. 1960. Atlas des bois de la Côte d'Ivoire. Centre Tech. For. Trop., Nogent-surMarne, Vol. 3: 263-393.

Normand, D. \& J. Paquis. 1976. Manuel d'identification des bois commerciaux. 2. Afrique guinéo-congolaise. Centre Tech. For. Trop., Nogent-sur-Marne.

Noshiro, S. \& P. Baas. 1998. Systematic wood anatomy of Cornaceae and allies. IAWA J. 19: 43-97.

Ogata, K. \& A. Kalat. 1997. Wood anatomy of some trees, shrubs and climbers in Brunei Darussalam.

Ohtani, J. 1984. SEM observations on perforation plates in some Rubiaceae. In: Pacific Regional Wood Anatomy Conference: 61-63. Tsukuba.

Ohtani, J. 1986. Vestures in axial parenchyma cells. IAWA Bull. n.s. 7: 39-45.

Ohtani, J. 1987. Vestures in septate wood fibres. IAWA Bull. n. s. 8: 59-67.

Oteng-Amoako, A.A. 1992. Photomicrographie atlas of Papua New Guinea timbers. Forest Research Institute, Papua New Guinea.

Panshin, A.J. 1932. An anatomical study of the woods of the Philippine mangrove swamps. Philipp. J. Sci. 48: 143-207.

Pearson, R.S. \& H.P. Brown. 1932. Commercial timbers of India. Volume 2. Their distribution, supplies, anatomical structure, physical and mechanical properties and uses. Central Publ. Branch, Govt. of India, Calcutta.

Persson, C. 1996. Phylogeny of the Gardenieae (Rubiaceae). Bot. J. Linn. Soc. 121: 91-109.

Persson, C. 2000. Phylogeny of the neotropical Alibertia group (Rubiaceae), with emphasis on the genus Alibertia, inferred from ITS and 5S ribosomal DNA sequences. Amer. J. Bot. 87: $1018-1028$.

Pfeiffer, H. 1925. Über die Wasserstoffionenkonzentration (H') als Determinationsfaktor physiologischer Gewebegeschehen in der sekundären Rinde der Pflanzen. New Physiol. 24: 65-98.

Piesschaert, F., L. Andersson, S. Jansen, S. Dessein, E. Robbrecht \& E. Smets. 2000a. Searching for the taxonomic position of the African genus Colletoecema (Rubiaceae): morphology and anatomy compared to an rps16-intron analysis of the Rubioideae. Can. J. Bot. 78: 288-304.

Piesschaert, F., S. Huysmans, I. Jaimes, E. Robbrecht \& E. Smets. 2000b. Morphological evidence for an extended tribe Coccocypseleae (Rubiaceae-Rubioideae). Plant Biol. 2: 536543.

Piesschaert, F., S. Jansen, I. Jaimes, E. Robbrecht \& E. Smets. In press. Notes on the morphology, anatomy, and taxonomic position of Pagameopsis (Rubiaceae-Rubioideae). Brittonia.

Piesschaert, F., E. Robbrecht \& E. Smets. 1997. Dialypetalanthus fuscescens Kuhlm. (Dialypetalanthaceae): the problematic taxonomic position of an Amazonian endemic. Ann. Missouri Bot. Gard. 84: 201-223.

Pobéguin, T. 1943. Les oxalates de calcium chez quelques angiospermes: étude physico-chimique. Ann. Sci. Nat. Bot. 4: 1-95.

Puff, C. 1988. Observation on Carphalea Juss. (Rubiaceae, Hedyotideae), with particular reference to the Madagascan taxa and its taxonomic position. Bull. Jard. Bot. Natl. Belg. 58: 271-323.

Puff, C. \& A. Igersheim. 1994a. The character states of Mussaendopsis Baillon (RubiaceaeCoptosapelteae). Flora 189: 161-178.

Puff, C. \& A. Igersheim. 1994b. Intra-ovarian trichomes in Jackiopsis ornata (Wallich) Ridsdale (Rubiaceae-Jackieae). Bot. J. Linn. Soc. 115: 29-33. 
Puff, C. \& U. Rohrhofer. 1993. The character states and taxonomic position of the monotypic mangrove genus Scyphiphora (Rubiaceae). Opera Bot. Belg. 6: 143-172.

Purkayastha, S.K. 1982. Indian woods, their identification, properties and uses. Vol. IV. Myrtaceae to Symplocaceae. Controller of Publications, Delhi.

Purkayastha, S.K. 1996. A manual of Indian timbers. Sribhumi Publishing, Calcutta.

Razafimandimbison, S.G. \& B. Bremer. 2000. Tribal and subtribal delimitation in the tribe Naucleeae (Rubiaceae): inferences from molecular and morphological data. Scripta Bot. Belg. 20: 75-76.

Record, S. J. \& G.A. Garrat. 1925. Boxwoods. In: School of Forestry Bulletin No. 14: 57-63. Yale University, New Haven.

Record, S.H. \& R.W. Hess. 1943. Timbers of the New World. School of Forestry, Yale University, New Haven.

Reinders, E. 1935. Fiber-tracheids, libriform wood fibers, and systematics in wood anatomy. Trop. Woods 44: 30-36.

Richter, H.G. \& U. Schmitt. 1987. Unusual crystal formations in the secondary xylem of Cosmocalyx spectabilis Standl. (Rubiaceae). IAWA Bull. n.s. 8: 323-329.

Ridsdale, C.E., R.C. Bakhuizen van den Brink \& J. Koek-Noorman. 1972. Notes on New Guinea Rubiaceae. Versteegia and Maschalodesme. Blumea 20: 339-348.

Robbrecht, E. 1977. The indumentum of Coptosapelta Korthals (Rubiaceae). Bull. Jard. Bot. Natl. Belg. 47: 258-259.

Robbrecht, E. 1986. Studies in tropical African Rubiaceae (7-12). 12. Further notes on Argocoffeopsis. Bull. Jard. Bot. Natl. Belg. 56: 157-161.

Robbrecht, E. 1988. Tropical woody Rubiaceae. Characteristic features and progressions. Contributions to a new subfamilial classification. Opera Bot. Belg. 1: 1-271.

Robbrecht, E. 1994. Supplement to the 1988 outline of the classification of the Rubiaceae. Index to genera. In: E. Robbrecht (ed.), Advances in Rubiaceae macrosystematics. Opera Bot. Belg. 6: 173-196.

Robbrecht, E. \& C. Puff. 1986. A survey of the Gardenieae and related tribes (Rubiaceae). Bot. Jahrb. Syst. 108: 63-137.

Rogers, G.K. 1981. The wood of Gleasonia, Henriquezia, and Platycarpum (Rubiaceae) and its bearing on their classification: some new considerations. Brittonia 33: 461-465.

Rogers, G.K. 1984. Gleasonia, Henriquezia, and Platycarpum (Rubiaceae). Flora Neotropica Mon., No. 39.

Rogers, G.K. 1987. The genera of Cinchonoideae (Rubiaceae) in the southeastern United States. J. Arnold Arbor. 68: 137-183.

Rova, J.H.E. 1999. The Rondeletieae-Condamineeae-Sipaneeae complex (Rubiaceae). Unpublished PhD-thesis, Göteborg University.

Royal Botanic Gardens, Kew. 2000a. Kew Record of Taxonomic Literature. http://www. rbgkew.org.uk/kr/KRHomeExt.html.

Royal Botanic Gardens, Kew. 2000b. Plant Micromorphology Bibliographic Database (PMBD). http://www.rbgkew.org.uk/kr/pa/PAHome.html.

Rudall, P. J. 1982. An unusual perforation plate in Canthium barbatum Seem. (Rubiaceae). IAWA Bull. n.s. 3: 127-129.

Sakala, J., D. Privé-Gill \& J-C. Koeniguer. 1999. Silicified angiosperm wood from the Dangu locality (Ypresian of the Gisors region, Eure, France): the problem of root wood. C. R. Acad. Sci. Paris, Sciences de la terre et des planètes 328: 553-557.

Schweingruber, F.H. 1990. Anatomie europaïscher Hölzer. Anatomy of European Woods. Verlag Paul Haupt, Bern \& Stuttgart.

Scurfield, G., C.A. Anderson \& E.R. Segnit. 1974. Silica in woody stems. Aust. J. Bot. 22: 211-229. 
Solereder, H. 1885. Über den Systematischen Wert der Holzstructur bei den Dicotyledonen. $\mathrm{PhD}$-thesis, München.

Solereder, H. 1893. Ein Beitrag zur anatomischen Characteristik und zur Systematik der Rubiaceen. Bull. Herb. Boiss. 1: 309-326.

Solereder, H. 1899. Systematische Anatomie der Dicotyledonen. Stuttgart.

Soltis, D.E., P.S. Soltis, M.W. Chase, M.E. Mort, D.C. Albach, M. Zanis, V. Savolainen, W.H. Hahn, S.B. Hoot, M.F. Fay, M. Axtell, S.M. Swensen, K.C. Nixon \& J.S. Farris. 2000. Angiosperm phylogeny inferred from a combined data set of $18 \mathrm{~S}$ rDNA, rbcL, and atpB sequences. Bot. J. Linn. Soc. 133: 381-461.

Sosef, M.S.M., L.T. Hong \& S. Prawirohatmodjo. 1998. Plant resources of South-East Asia. Timber trees: lesser known timbers. Backhuys Publishers, Leiden.

Taniguchi, T., H. Harada \& K. Nakato. 1982. Mineral deposits in some tropical woody plants. Ann. Bot. 50: 559-562.

Ter Welle, B. J.H. 1976. Silica grains in woody plants of the Neotropics, especially Surinam. In: P. Baas, A. J. Bolton \& D.M. Catling (eds.), Wood structure in biological and technological research: 107-142. Leiden Botanical Series 3.

Ter Welle, B. J.H., A.A. Loureiro, P.L.B. Lisboa \& J. Koek-Noorman. 1983. Systematic wood anatomy of the tribe Guettardeae (Rubiaceae). Bot. J. Linn. Soc. 87: 13-28.

Tippo, O. 1940. The comparative anatomy of the secondary xylem and the phylogeny of the Eucommiaceae. Amer. J. Bot. 27: 832-838.

Vales, M.A. 1983a. Verzierte einfache Gefässdurchbrechungen im Holz einiger endemischer Rubiaceen-Arten aus Kuba. Feddes Repert. 94: 493-495.

Vales, M.A. 1983b. Verzierte Gefäss- und Holzfaser-Hoftüpfel im Holz einiger endemischer Rubiaceen-Arten aus Kuba. Feddes Repert. 94: 497-500.

Vales, M.A. \& K. Babos. 1977. Wood anatomy of Ceratopyxis Hooker f. ex Hooker (Rubiaceae), a monotypic genus of West Cuba. Acta Bot. Hung. 23: 275-283.

Vales, M.A. \& H. Süss. 1985a. Die Holzanatomie der in Kuba endemischen Rubiaceae Phyllomelia coronata Griseb. und Ceratopyxis verbenacea (Griseb.) Hook. f. ex Hook. Feddes Repert. 96: 227-233.

Vales, M.A. \& H. Süss. 1985b. Die Holzanatomie der in Kuba endemischen Rubiaceae Acuneanthus tinifolius (Griseb.) Borhidi, Ariadne shaferi (Standl.) Urb. und Neomazae phiallanthoides (Grieseb.). Feddes Repert. 96: 215-225.

Van Riemsdijk, H.M.D. 1875. Anatomisch onderzoek van het hout van eenige tropische Rubiaceëen. Proefschrift, University of Leiden.

Verdcourt, B. 1958. Remarks on the classification of the Rubiaceae. Bull. Rijksplantentuin Bruss. 28: 209-281.

Vrydaghs, L., H. Doutrelepont, S. Jansen, E. Robbrecht \& H. Beeckman. 1995. De la valeur systématique des phytolithes dans le bois des Naucleeae (Rubiaceae). Biol. Jaarb. Dodonaea 63: 161-173.

Wagner, L.L., D.R. Herbst \& S.H. Sohmer. 1989. Manual of the flowering plants of Hawaii. Hawaii, University of Hawaii Press.

Williams, L. 1936. Woods of northeastern Peru. Field. Mus. Nat. Hist., Bot. ser. 15: 1-587. Chicago.

Young, M.C.M., M.R. Braga, S.M.C. Dietrich, V.S. Bolzani, L.M.V. Trevisan \& O.R. Gottlieb. 1996. Chemosystematic markers of Rubiaceae. In: E. Robbrecht, C. Puff \& E. Smets (eds.), Second International Rubiaceae Conference, Proceedings. Opera Bot. Belg. 7: 205-212. 